\title{
Kill Your Darlings, Caracas: Space as Currency in Venezuela's Capital City
}

\author{
by \\ Gabriella Douglas
}

A thesis submitted to the Faculty of Graduate and Postdoctoral Affairs in partial fulfillment of the requirements for the degree of

Master of Architecture

in

M.Arch Professional

Carleton University

Ottawa, Ontario

(C) 2017

Gabriella Douglas 


\section{Abstract}

Due to the unrivaled efficiency of digital banking, paper currency is facing obsolescence. Profiles may be permanently etched on the surface of bank notes, coins, and cheques, but the manner in which these vestiges narrate our lapsed human relationships will ultimately contribute to re-defining a nation's identity, and the space of its capital city.

Over the past quarter century, Caracas, Venezuela has been subject to a spectrum of economic trends: politically advantageous oil trades in the 1980s and 1990s, The 1994 Banking Crisis, inflation rates reaching an annual height of 500\% from 2015 to 2017, and a series of corrupt administrations which have ignited heinous crimes, ongoing exponential growth in impoverished neighbourhoods, and the current extreme shortages of basic living supplies. It has been labeled the world's most violent city.

This thesis will investigate the capital city of Caracas and its systems of exchange, expropriations and exploitation, all in the context of an evolving spatial currency. It will ask the question: how can we reveal exchange value as a function of spatial networks, and at shifting scales? 


\section{Acknowledgements}

To Jill, for pushing me,

To Ozayr, for catching me.

To Mackenzie, for your unconditional faith in me,

To my brothers-in-law, for your guidance.

To Kamila, for your companionship in the trenches,

To Evan, for your silent support and humour.

To my friends, for reminding me how big the world is.

And finally,

To Dani and Katita,

Mama and Dad;

For everything you are, everything you've done,

Everything I am and everything I will become. 


\section{Table of Contents}

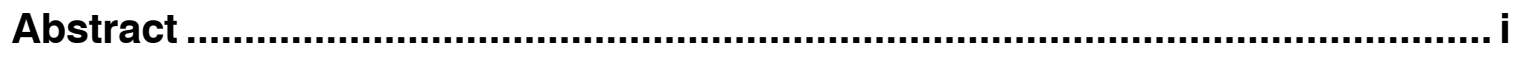

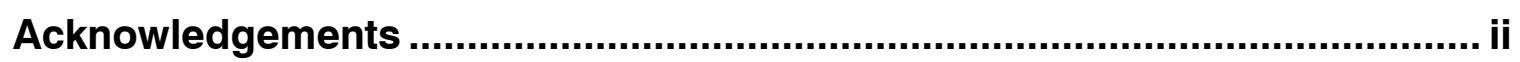

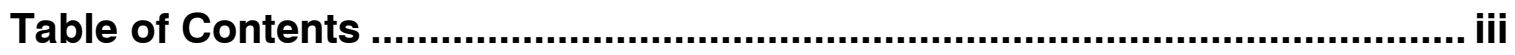

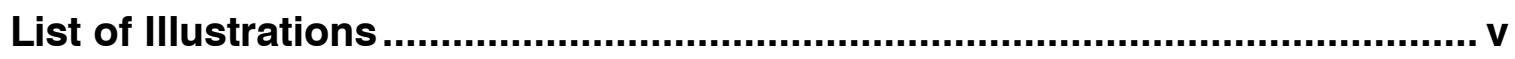

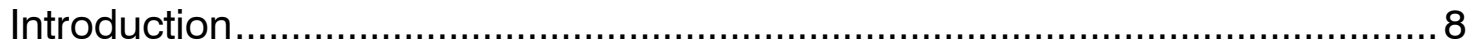

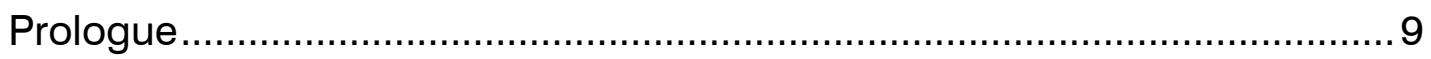

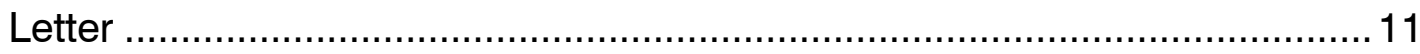

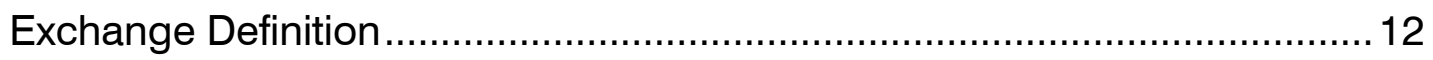

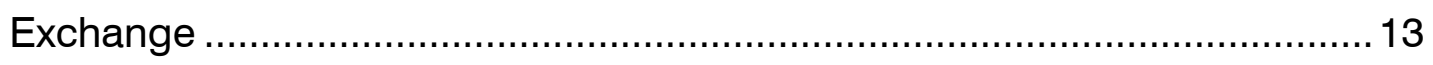

Chapter 1: The Death of Currency ........................................................... 17

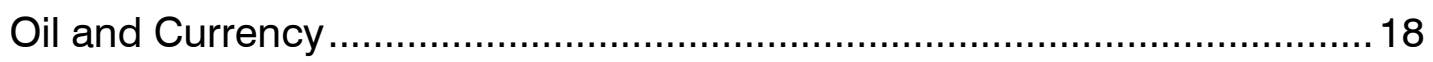

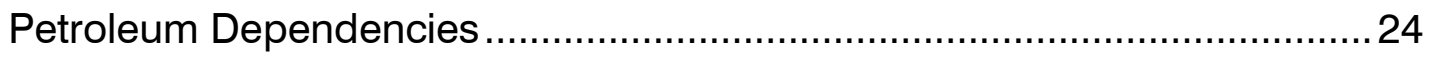

Chapter 2: The City in the Currency .......................................................... 34

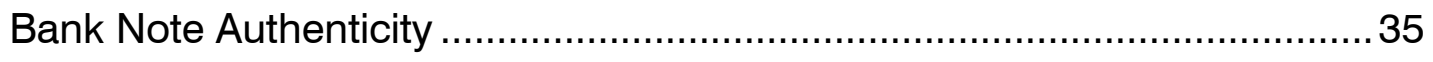

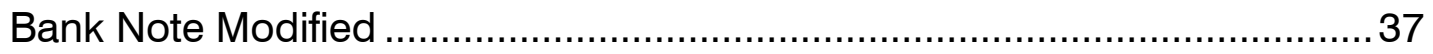

Chapter 3: The Currency in the City ............................................................ 47

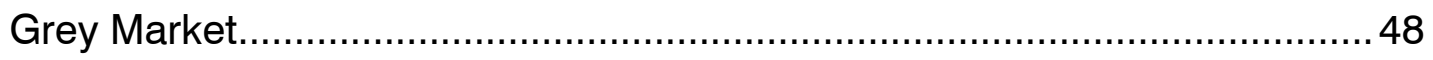

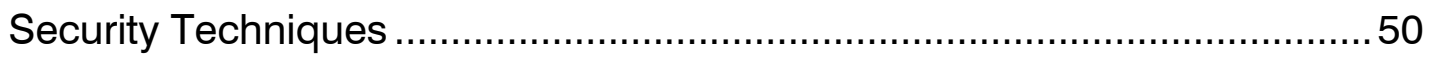

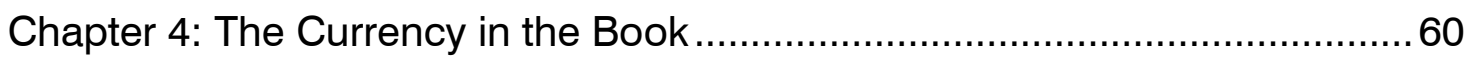

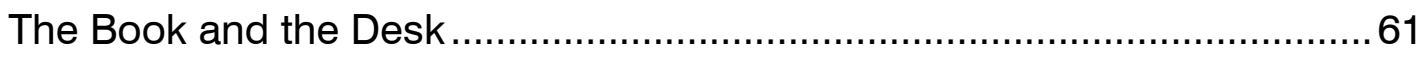

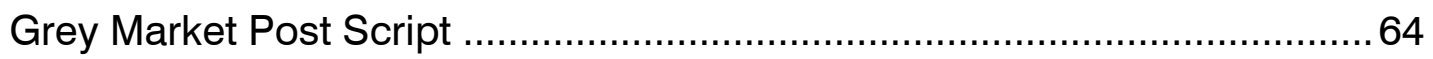


Chapter 5: Five Essays on Spatio-Economic Phenomena.............................80

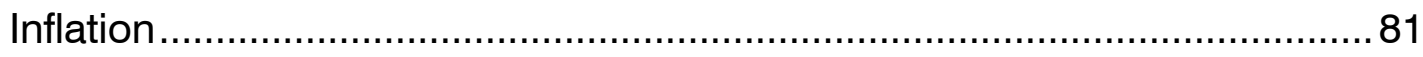

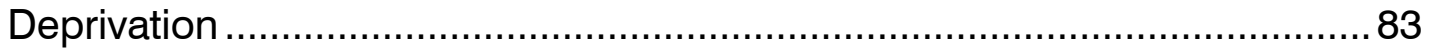

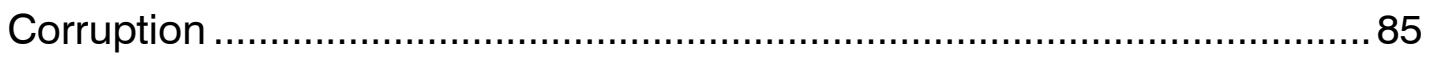

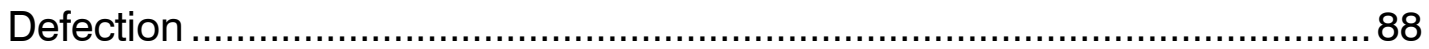

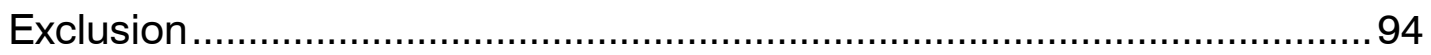

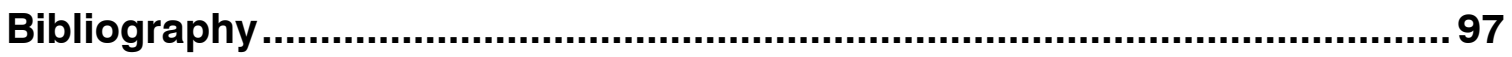




\section{List of Illustrations}

Figure 0-1:77 Years of Venezuelan Bank Notes ............................................ 14

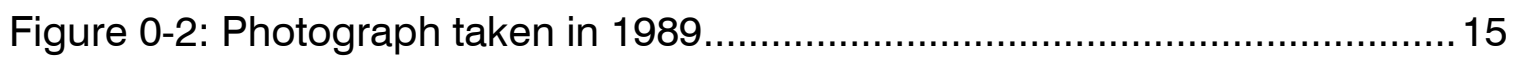

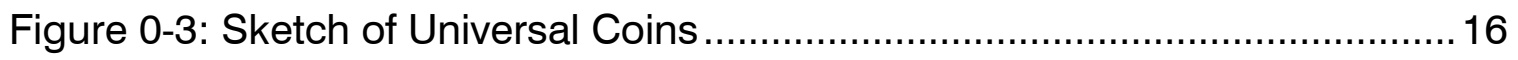

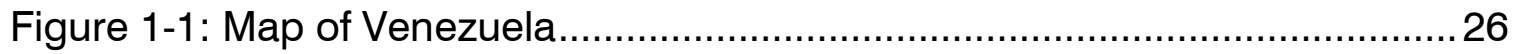

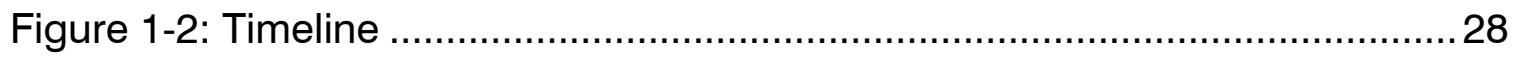

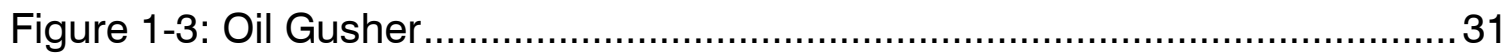

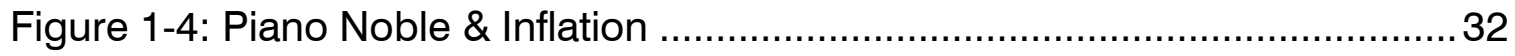

Figure 1-5: Venezuela's Inflation Rate .......................................................... 33

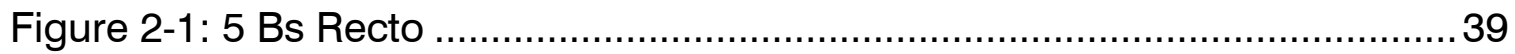

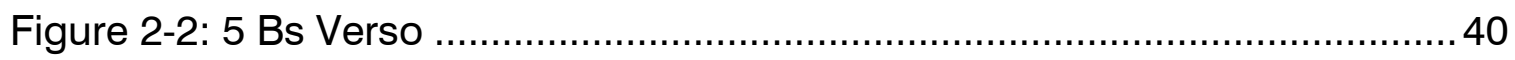

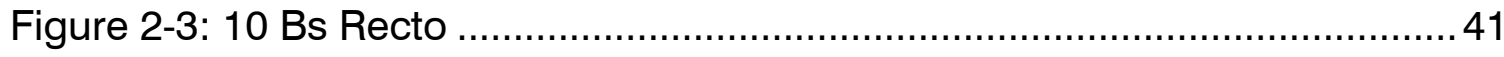

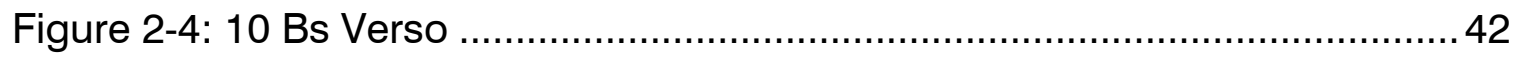

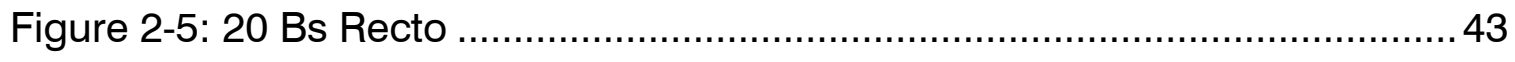

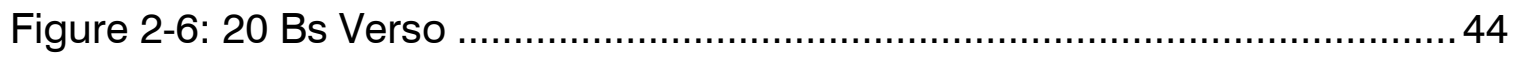

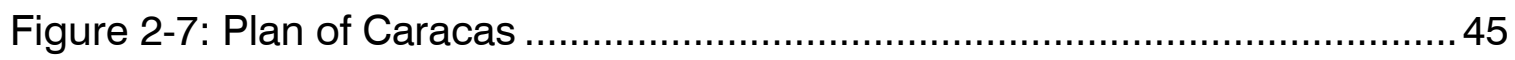

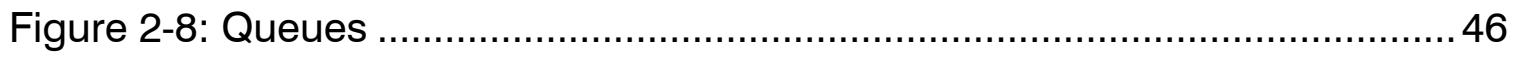

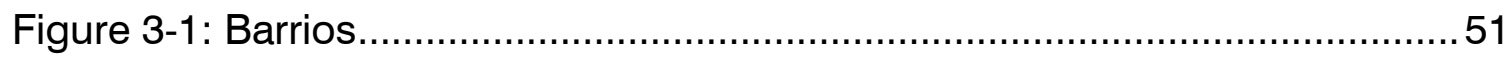

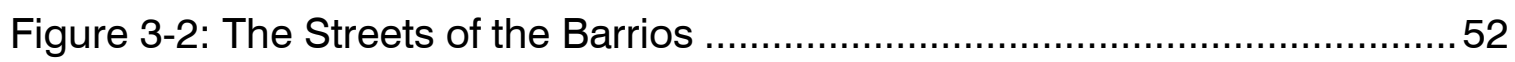

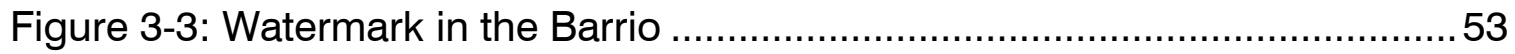

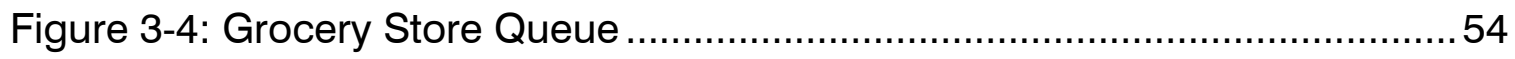

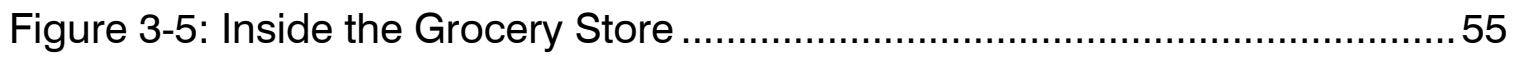




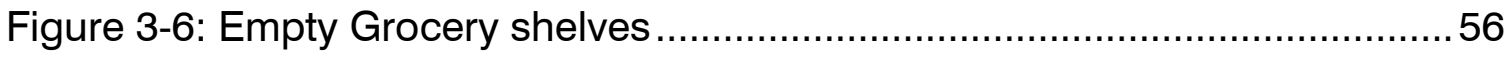

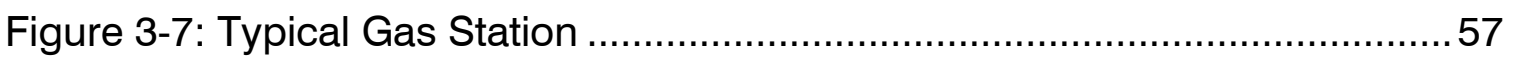

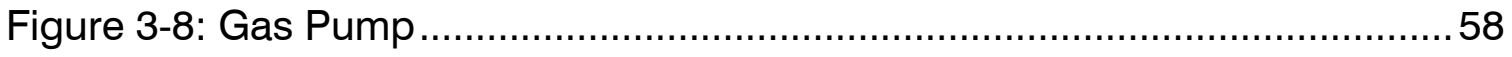

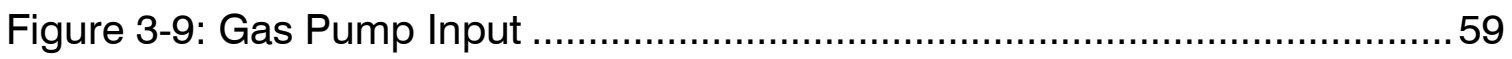

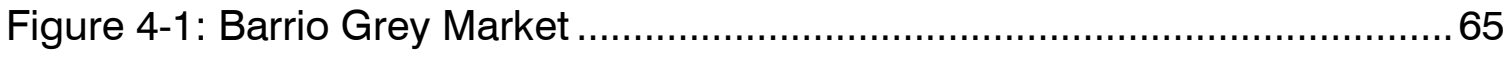

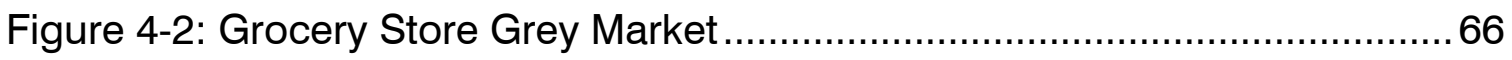

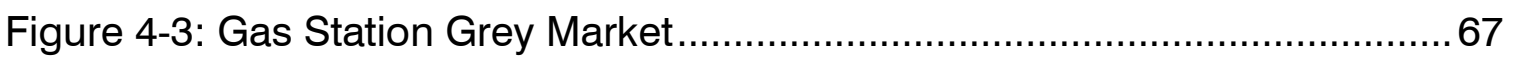

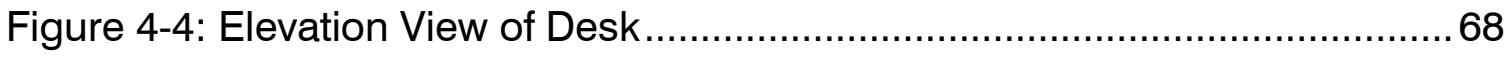

Figure 4-5: Perspective View of Top of Desk ..................................................69

Figure 4-6: Perspective View of Side of Desk ................................................... 70

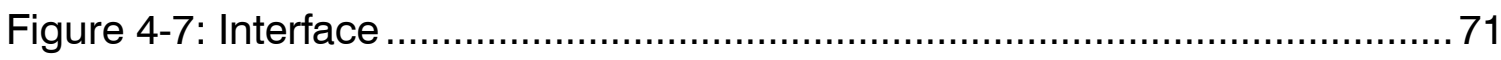

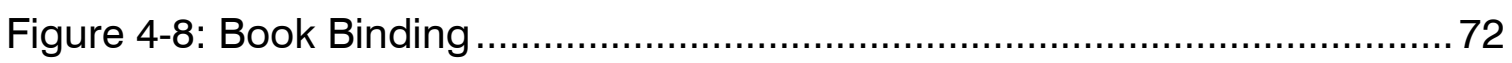

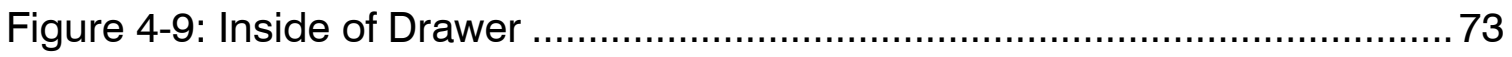

Figure 4-10: Focus of Caracas Plan Extrusion ……….................................. 73

Figure 4-11: Focus of Text Etch on Skirt of Desk ........................................... 74

Figure 4-12: Focus on Locating Pins .......................................................... 74

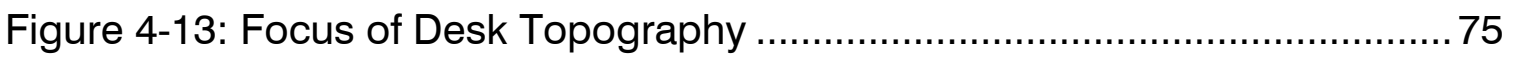

Figure 4-14: Chapter Cover Page of Book [Laser Cut on Kraft Paper] ............... 75

Figure 4-15: Postcard Page of Book [Gesso on Newsprint] ..............................76

Figure 4-16: Grey Market Page of Book [Xylene on Newsprint] .........................76

Figure 4-17: 5 Bolivars Modified Page of Book [Acetate Print] ..........................77

Figure 4-18: 5 Bolivars Modified Page of Book [Newsprint Print]........................77 
Figure 4-19: Plan of Caracas Page of Book [Acetate on Newsprint].....

Figure 4-20: Collection of Material Studies ................................................... 78 


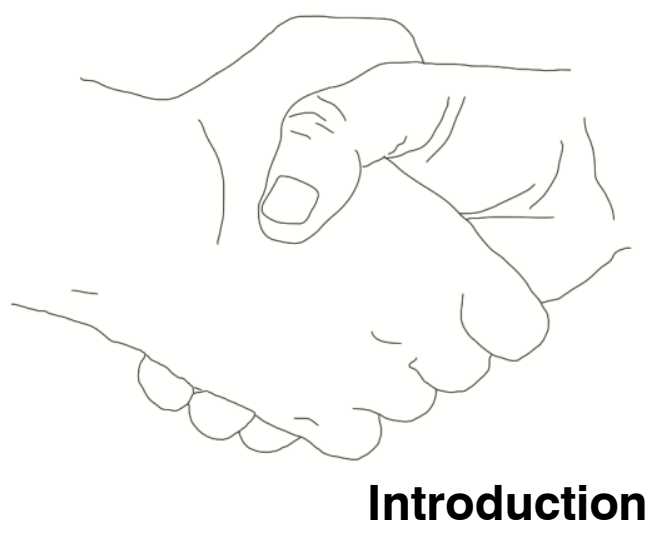




\section{Prologue}

The idea for this thesis came to me when I was accompanying my father on his visit to a coin dealer, in a shop located between a video gaming store and a money mart on the fringes of Ottawa. Since there were bars behind the windows, I thought this store must be highly subject to theft. My father rang the doorbell, and a man came to open the door for us. As he and my father spoke of coins they had just found or conversations with other dealers and collectors they knew, I looked around the store. Doorbell entrance? Bars on windows? An employee who is barely there? I thought to myself: 'How is this place surviving?'

"It's a niche market," my father told me later on our way home. I thought about the collectible bank notes and coins that we had seen. In fact, I thought about this all summer, every time I paid for something with my debit or credit card.

The obsolescence of physical currency is inevitable. I was fascinated by the questions that this generates: what will our relationship be to currency, when the modes of currency change?

The interplay between the complementary forces of currency and exchange are twin vectors of this thesis exploration. I brought the question of these emerging relationships to the scale of a major metropolis, so that I could work at multiple scales, engage the complexities of urban politics, resource value and social complexity. I chose Caracas for reasons purely personal; yet it is a city that lends itself to this study in extremes. 
My mother, pregnant with my second sister, immigrated to Canada from Venezuela in the fall of 1985 with my eldest sister, who was one year old at the time. Today, more than ten of her siblings and their families still live in Venezuela, with the majority of whom in Caracas. I have visited Caracas six times since my birth, for about two months each time. I thought I knew Caracas well. It was not until I began investigating the country's systems of exchange and hyper-inflating currency that I discovered how little I had previously comprehended about the capital.

Borrowed from its author William Faulkner, the phrase 'kill your darlings' is a literary term encouraging writers not to be precious with the lives of beloved characters in a story, if finding that the story as a whole is suffering due to a lack of synergy. In regard to Caracas, the beloved characters are the systems of exchange within the network of the city that have proven lucrative in the past, but are now handicaps.

Kill Your Darling, Caracas is about basic relations, about how we engage and interact with each other, with space, and with social infrastructure. The city is a web of relationships - ordered, fostered, conducted and organized through space. Caracas is not only a site; it is a system of movements and exchanges, involving oil, words, money, resources, transparency, bodies in space. These become spatial currencies, operating at multiple scales.

This thesis forms a resistance against the prevailing phenomena of inflation, defection, starvation, deprivation, and exclusion. 


\section{Letter}

Beloved Elba,

It's taken me a while to sum up the courage to write this to you. Your father's dementia has gotten worse and it's becoming harder and harder to get the medicine for him. It's roughly 20 times more expensive this month than it was last month... but what does it matter when the medicine isn't even in the country. Your brother has tried to find it on the black market but he's afraid of what will happen if he goes alone. To make matters worse, Raul lost his job, so the kids have to start selling food downtown. I don't know how much more I can take. Don't bother sending money; this country is so corrupt it won't make it to my account. May God Bless your beautiful family in Canada while he's forgetting about ours here.

Mama Carmen ${ }^{1}$

1 Original author. "Letter to Elba." Dramatized non-fiction. 


\section{Exchange Definition}

\section{Exchange [transitive verb]}

1a : to part with, give, or transfer in consideration of something

Received as an equivalent

b : to have replaced by other merchandise <exchanged the

shirt for one in a larger size >

2: to part with for a substitute <exchanging future security for

Immediate pleasure >

3: to give and receive reciprocally <exchange gifts>

Exchange [intransitive verb]

1: to pass or become received in exchange

2: to engage in an exchange

Origin and Etymology of exchange

Middle English exchaunge, from Anglo-French eschange, from eschanger to

exchange, from Vulgar Latin excambiare, from Latin ex- + cambiare to exchange

First Known Use: 14th century ${ }^{2}$

2 "Exchange." Merriam-Webster. Merriam-Webster, n.d. Web. 21 Mar. 2017. 


\section{Exchange}

The physical act of exchange is spatial and deeply rooted in social, economic and political practices. Our relationships with one another have evolved with the parting, offering, substituting, giving and transferring of currencies, which are defined as systems of exchange in consideration of something received as an equivalent (Figure $0-1$ ). The physical act of exchange can be understood as a form of energy. Energy cannot be created or destroyed, only transferred. ${ }^{3}$

In the case of economics, the exchange of paper currency is a physical energy shared between acting members of the economic structure. If the systems of exchange continue to adapt the technological revolution's digital currency, the act of exchange will transfer - just like energy - to an alternative venue.

What will these venues become? Will the population - deprived of value in their paper currency - morph into an unmitigated altered currency? Will these exchanges happen on the streets of the city or in sanctioned buildings? During daylight hours and freely, or in the dead of night beneath a veil of obscurity? Will the interaction be parties yelling from across the road their banking information, or will it be within the folds of a hand shake? Manifestation of areas of exchange will occur when participating members of the economic structure redefine their systems of exchange.

\footnotetext{
3 Feinberg, Gerald, and Maurice Goldhaber. "The Conservation Laws of Physics." Scientific American. Scientific American Published, 26 Aug. 2013. Web. 21 Mar. 2017.
} 

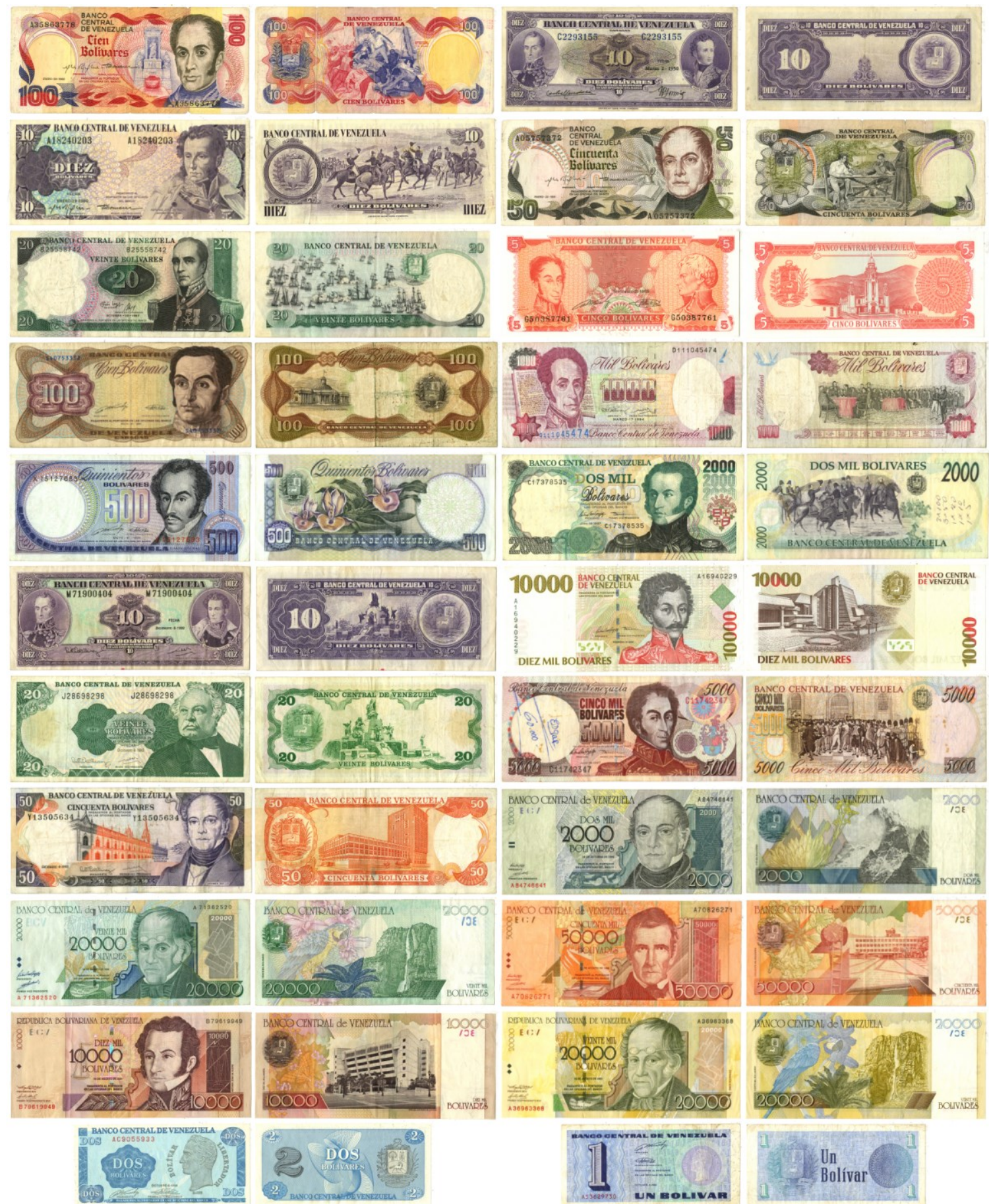

\section{Figure 0-1:77 Years of Venezuelan Bank Notes}

A personal collection of Venezuela's bank notes over several decades showcases the vivid colours and type chosen to represent the country's currency 22 bank notes are displayed, in both recto and verso. 


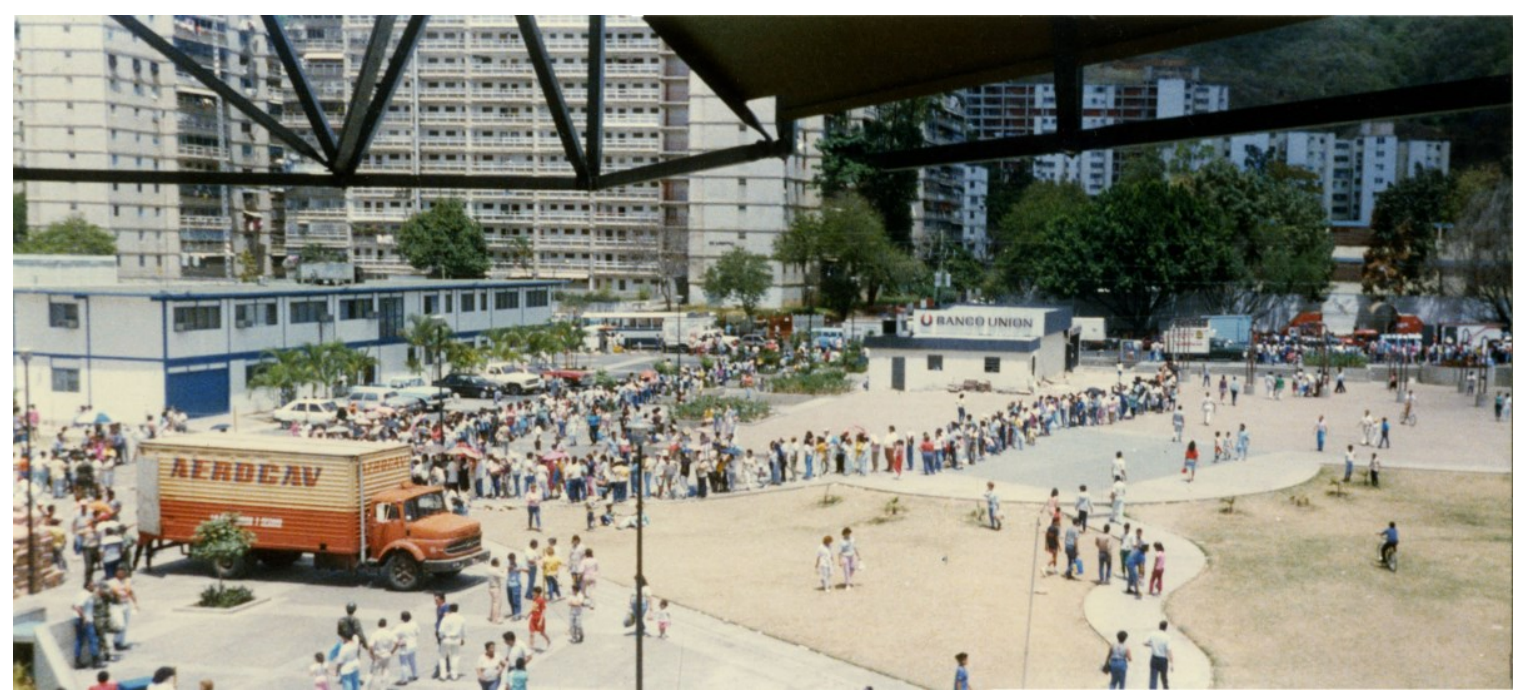

Figure 0-2: Photograph taken in 1989

Photograph taken by my father in 1989 from a metro stop in Caracas, looking at a city square. It is unclear what the people queued up for. 


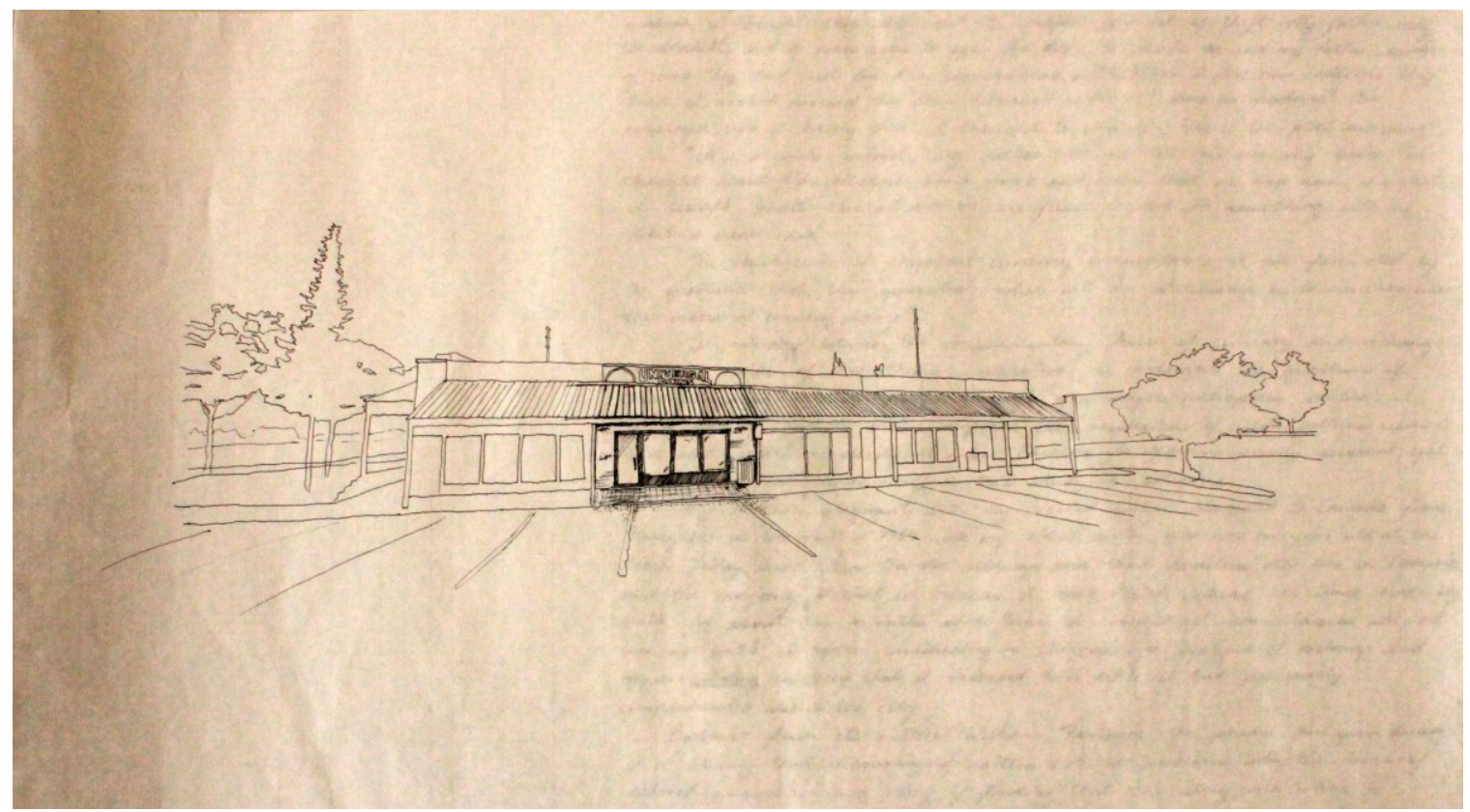

Figure 0-3: Sketch of Universal Coins

Coin store in Ottawa. Original author. 


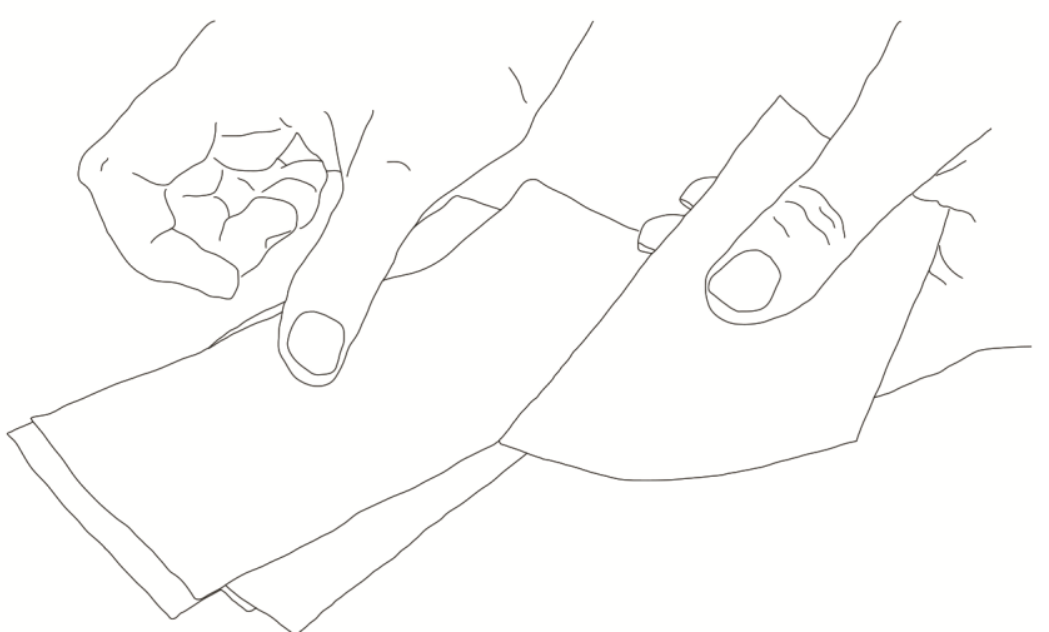

Chapter 1: The Death of Currency 


\section{Oil and Currency}

The value of oil is directly related to the current economic crisis in Caracas. Venezuela's contemporary oil industry was marked in 1917 when the first oil refining operations begin at Paraguaná Refinery Complex (Figure 1-2). ${ }^{4}$ After 1922, throngs of oil companies began to converge in the country, and by 1929 Venezuela had grown to be the world's second largest producer of oil. ${ }^{5} \mathrm{~A}$ new government similar to a dictatorship introduced a 50/50 split in profits between the government and the oil industry in 1943, and began the country's spread of Dutch Disease. $^{6}$

Venezuela's economy formerly comprised farming, manufacturing and trading within its borders; ${ }^{7}$ the Oil Boom in the 1950 s dramatically transformed the country. The scale of its oil production gave reason for Venezuela to make the transition from a primordial society with an economy based on elemental agriculture and an undereducated population whose health was poor, into a healthy, educated society within a modern country, and a strong middle class as the nucleus of economic advancement. ${ }^{8}$ The plan was based on the government's

4 PDVSA. "History." Petroleos De Venezuela SA. Gobierno Bolivarian De Venezuela, n.d. Web. 30 Mar. 2017.

${ }^{5}$ Coronil, Fernando. "Oil and Revolution." Venezuela: The Chavez Effect. ReVista: Harvard Review of Latin America. David Rockefeller Center for Latin American Studies. Vol. VIII, No.1. Harvard University. Fall 2008.

${ }^{6}$ Pennsylvania State University. "Fifty-Fifty: The New Deal in Oil." Oil: International Evolution. Penn State College of Earth and Mineral Science, n.d. Web. 21 Mar. 2017.

7 Marden, Luis. "Caracas, Cradle of The Liberator: The Spirit of Simon Bolivar, South American George Washington, Lives On in the City of His Birth." National Geographic Magazine. National Geographic Society. Vol. LXXVII, No.4. Washington D.C. April 1940.

${ }^{8}$ Coronil, Fernando. "Oil and Revolution." Venezuela: The Chavez Effect. ReVista: Harvard Review of Latin America. David Rockefeller Center for Latin American Studies. Vol. VIII, No.1. Harvard University. Fall 2008. 
unrestricted spending of the rent, however the oil industry was an authorization and the coupling of oil and society was altogether fiscal for many decades. ${ }^{9}$

As the country's Gross Domestic Product (GDP) grew, Venezuela became increasingly amalgamated with the global economic society. The lucrative benefits of the oil industry enticed many Venezuelans to leave their low earning jobs to work in the refineries, emphasizing to the political class the significance of the oil-based economy. ${ }^{10}$ Venezuela's new identity as a global oil producer became the forefront of the national conversation.

Venezuela joined OPEC in 1960, and has since been heavily dependent on its own crude oil reserves, which account for a third of the country's GDP. ${ }^{11}$ The 1960s, 1970 s and the early 1980 s turned Venezuela into a 'promise land' in South America. Destination spots like the Avila National Parks, The Cableway of Caracas, CCT Mall and other city center attractions were built, cruise ships docked on the coast to bring tourists into the city. Money was being made,

\footnotetext{
${ }^{9}$ Coronil, Fernando. "Oil and Revolution." Venezuela: The Chavez Effect. ReVista: Harvard Review of Latin America. David Rockefeller Center for Latin American Studies. Vol. VIII, No.1. Harvard University. Fall 2008.

10 Abercrombie, Thomas, J. "Venezuela Builds on Oil." National Geographic Magazine. National Geographic Society. Vol. 123, No.3. Washington, D.C. March, 1963.

11 OPEC. "Member Countries." OPEC : Member Countries. Organization of the Petroleum Exporting Countries, 2015. Web. 21 Mar. 2017.
} 
mansions were being constructed by the oil barons, and the economy as a whole soared to new economic heights. ${ }^{12}$ And then it fell.

In the fall of 1985 , the Venezuelan Bolivar's ${ }^{13}$ (Bs), exchange rate was 4 Bs to 1 USD. The Bolivar remained relatively stable until Venezuela saw its economic structure implode in the 1994 Banking Crisis. The first bank to fail was Banco Latino - at the time the country's second largest bank - in January 1994. The collapse of the Banco Consolidado, Banco Venezuela, and others soon followed. ${ }^{14}$ Eventually, the Venezuelan government had no choice but to seize control of the banks. From 1994 to mid-1995, 17 of the 49 Venezuela's commercial banks and subsidiaries failed. The estimated total cost of the bank bailouts months after the incident was $\$ 6.1$ Billion USD. ${ }^{15}$ In 1994 , the original bailout estimate was roughly " $11 \%$ of the country's gross national product and 75 percent of the Government's 1994 national budget."16

The 1994 Banking Crisis led to sharply reduced government spending; serious infrastructure projects like railways were suspended, the Barrios city maintenance was terminated, commercial roads were no longer treated for repairs

\footnotetext{
12 Abercrombie, Thomas, J. "Venezuela Builds on Oil." National Geographic Magazine. National Geographic Society. Vol. 123, No.3. Washington, D.C. March, 1963.

13 The Bolivar is the name of Venezuela's official currency.

14 Brooke, James. "Failure of High-Flying Banks Shakes Venezuelan Economy." The New York Times. The New York Times, 15 May 1994. Web. 21 Mar. 2017.

15 Since then, economists have argued that it had grown closer to \$12 Billion USD total.

16 Brooke, James. "Failure of High-Flying Banks Shakes Venezuelan Economy." The New York Times. The New York Times, 15 May 1994. Web. 21 Mar. 2017.
} 
and civil servants saw their salaries drop. ${ }^{17}$ Over-printing and augmenting the denomination of the Venezuelan currency occurred so frequently, the value of the bills declined at an exponential rate, explaining why the exchange rate is as low as it is today, along with the infrastructural and sociological state of the country.

Frantic to avoid a sovereign default which would thereby suspend credit to the feeble oil industry, in 2003, President Hugo Chávez implemented "currency controls intended to bolster Venezuela's diminishing foreign reserves and price cuts on essential goods." ${ }^{18} \mathrm{~A}$ sharp decline in the price of oil, combined by years of failures and falsehoods from the now late Hugo Chávez's and his successor, Nicolás Maduro, were instrumental in the paramount nose-dive of the country's economy. ${ }^{19}$ In the spring of 2016, International Monetary Fund (IMF) forecasted Venezuela's inflation to rise around $500 \%$ that same year. ${ }^{20}$ Due to the over-

\footnotetext{
17 Gillespie, Patrick. "5 Reasons Why Venezuela's Economy Is in a 'meltdown'." CNNMoney. Cable News Network, 20 Jan. 2016. Web. 21 Mar. 2017.

18 Forero, Juan. "Venezuela Imposes Currency Controls to Shore Up Economy." The New York Times. The New York Times, 06 Feb. 2003. Web. 25 Mar. 2017.

${ }^{19}$ Venezuela is a socialist country. Socialism is defined as "any of various economic and political theories advocating collective or governmental ownership and administration of the means of production and distribution of goods," by Merriam-Webster Dictionary. The country's political structure under the current president Nicolas Maduro enables the performance legally and ethically questionable moves.

20 J.R.A. "Why Airlines Are Abandoning Venezuela." The Economist. The Economist Newspaper, 07 June 2016. Web. 28 Mar. 2017.
} 
printing of the Venezuelan' Bolivars, the currency's inflation rate has since been calculated, and ballooned closer to $700 \%$ in $2016 .{ }^{21}$

Chávez's restrictions had rendered the ability for independent companies hoping to buy USD with Bs nearly impossible by virtue of the tightened currency controls. Considering the Venezuelan banks are owned by the Venezuelan government, the official exchange rate of the Bolivar can only be used by government controlled environments - like the Banco De Venezuela - as an effort to divert the attention of the country's tattered economy. On November 9th, 2016, the exchange rate from United States of America's dollar to Venezuela's Bolivar was 1 USD to 9.95 Bs according to the Banco of Venezuela. The Venezuelan banks, however, cannot afford to buy USD with the near worthless Bolivars they possess. If the banks cannot afford to buy USD, how can the general public afford it?

Acquired from dolartoday.com, an online source that follows trading in street market - or the Black Market - where the general public goes to "skirt limits on foreign-exchange purchases." ${ }^{22}$, the graph represents the astronomically rising

\footnotetext{
21 “... annualized inflation now at $773 \%$ year-over year ending July." Rapoza, Kenneth. "Venezuela's Inflation Rate Now Approaching Lunacy Levels." Forbes. Forbes Magazine, 26 Aug. 2016. Web. 25 Mar. 2017.

22 Boyd, Sebastian. "Black-Market Bolivars Crash Past 1,000 Per Dollar in Venezuela."Bloomberg.com. Bloomberg, 03 Feb. 2016. Web. 28 Mar. 2017.
} 
exchange rates of the Bolivar from June 23rd 2010 to September 3rd 2016 (Figure $1-5)$. 


\section{Petroleum Dependencies}

Venezuela's most significant natural resources are petroleum and natural gas, gold, iron ore and other minerals. ${ }^{23}$ Located just south of the Caribbean Sea, Caracas rests in a valley at the foot of the Avila Mountains. This valley is elevated at approximately 2910' above sea level ${ }^{24}$, and thus forms a plateau, or mesa, or in architectural terms, a kind of 'Piano nobile' for the capital city (Figure 1-4).

Due to its topography, Venezuela has spawned two major oil fields; Lake Maracaibo, and the Orinoco River Delta. The greater oil extraction of the two, Lake Maracaibo, is connected to the Gulf of Venezuela resting to the East of the Andes (Figure 1-1).

Lake Maracaibo saw the first oil driller in 1922, and since then the country's petroleum industries "have shaped the country, affected the state and determined the social, economic and political life of the nation." ${ }^{25}$

Established in 1960, The Organization of the Petroleum Exporting Countries (OPEC) is comprised of over a dozen countries of proven crude oil reserves, which total $81 \%$ of the crude oil reserves in the world. Venezuela contributes $24.8 \%$ of OPEC's total, more than Saudi Arabia and Iran, and is the 5th largest oil producer in the world (Figure 1-3). ${ }^{26}$ Venezuela's contribution in

\footnotetext{
23 OPEC. "Venezuela." OPEC : Venezuela. OPEC, Jan. 2017. Web. 25 Mar. 2017.

24 Dateandtime.com. "Caracas, Venezuela.". Latitude, Longitude, and Elevation above Sea Level of Caracas. Date and Time.com, n.d. Web. 30 Mar. 2017.

25 PDVSA. "History." Petroleos De Venezuela SA. Gobierno Bolivarian De Venezuela, n.d. Web. 30 Mar. 2017.

26 OPEC. "Venezuela." OPEC : Venezuela. OPEC, Jan. 2017. Web. 25 Mar. 2017.
} 
petroleum exports make it a vital contributor to the world's global economy and affiliated energy industries. ${ }^{27}$

Petróleos de Venezuela S.A., more commonly known under its acronym PDVSA, was Latin America's largest single corporation at the beginning of the millennium but stood as one of the least efficient. In 2005, it cost PDVSA "about three times as much to extract a barrel of oil as it cost other major oil corporations, such as Exxon Mobil, Shell or Chevron Texaco." ${ }^{28}$ Oil revenues account for 94.2\% of the country's export earnings. ${ }^{29}$

27 PDVSA. "History." Petroleos De Venezuela SA. Gobierno Bolivarian De Venezuela, n.d. Web. 30 Mar. 2017.

28 PDVSA. "History." Petroleos De Venezuela SA. Gobierno Bolivarian De Venezuela, n.d. Web. 30 Mar. 2017.

29 OPEC. "Venezuela." OPEC : Venezuela. OPEC, Jan. 2017. Web. 25 Mar. 2017. 


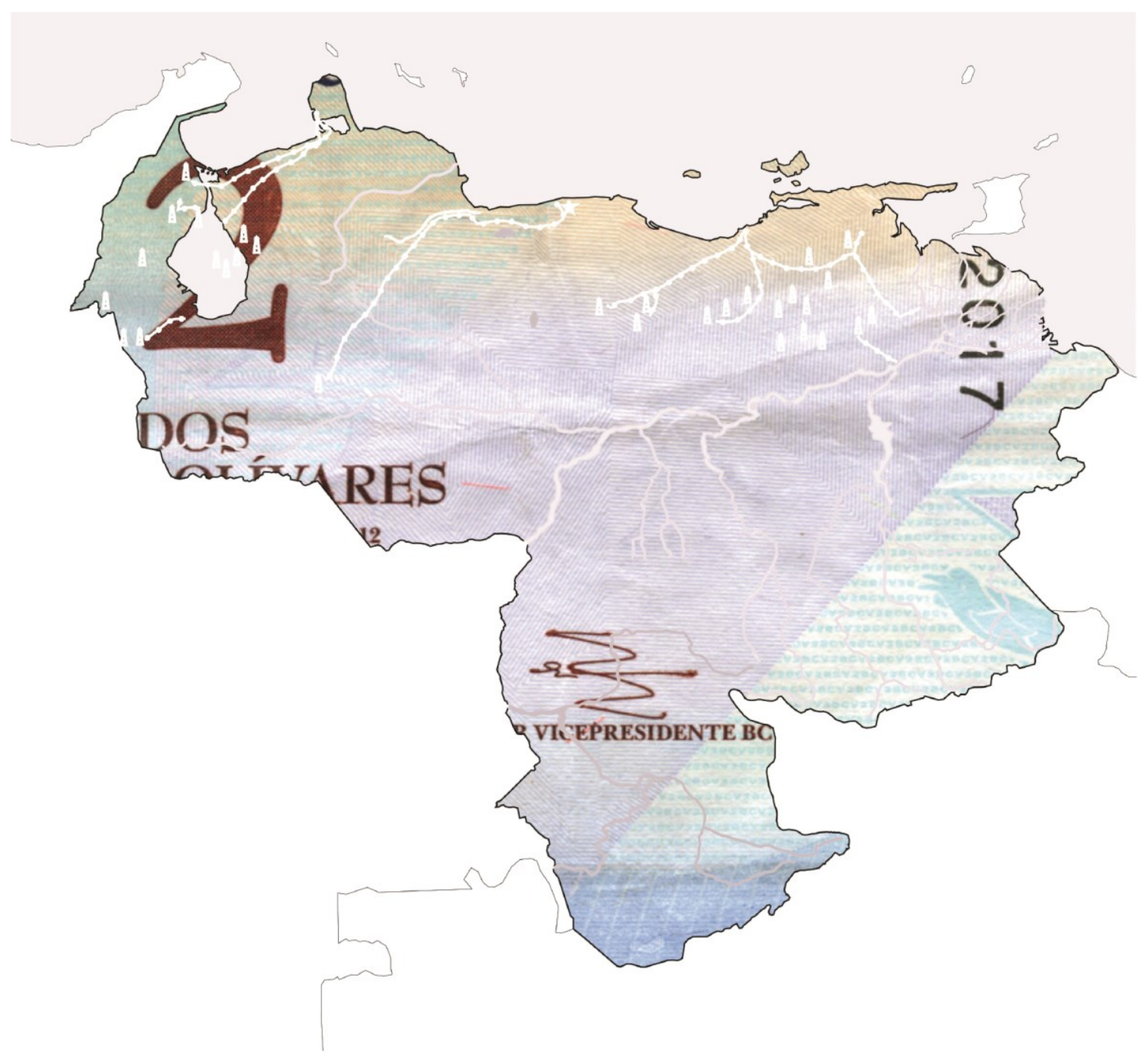

Figure 1-1: Map of Venezuela

This plan of Venezuela indicates where the country is geographically located. The oil pipelines and rigs are strung inside the country. A 2 Bs bank note rests in the background. Original author. 


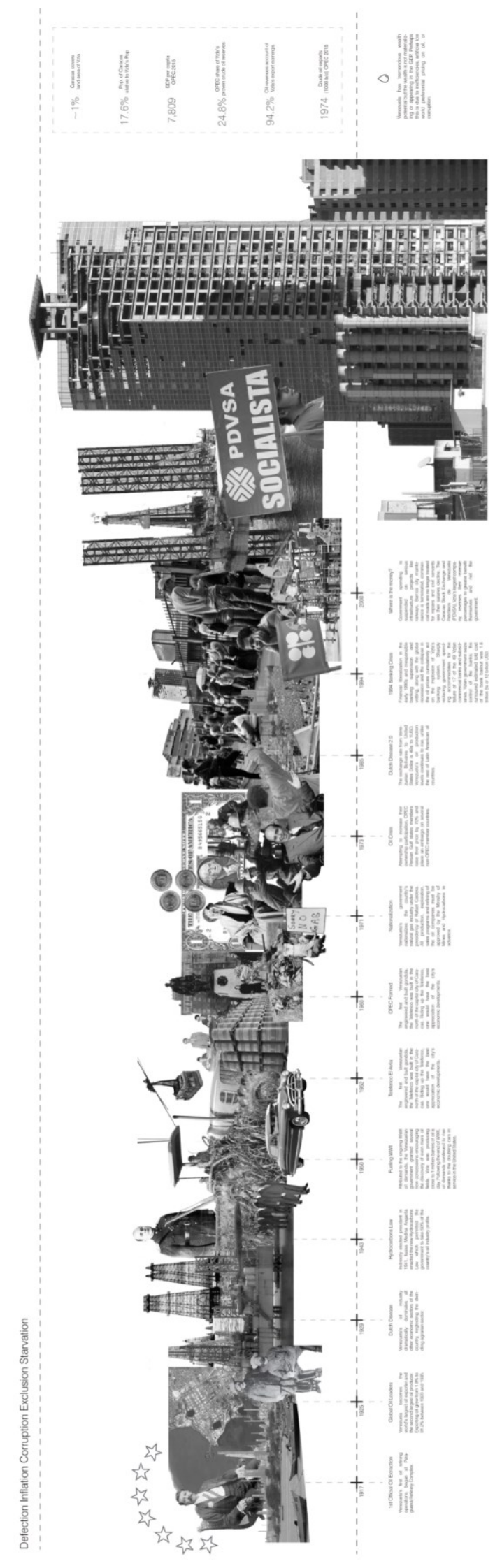


Figure 1-2: Timeline

The Timeline explains through text and imagery the causes and effects of Venezuela's economic rise and fall. Pages 28-30 are large scaled portions of Timeline for legibility purposes. Original author.

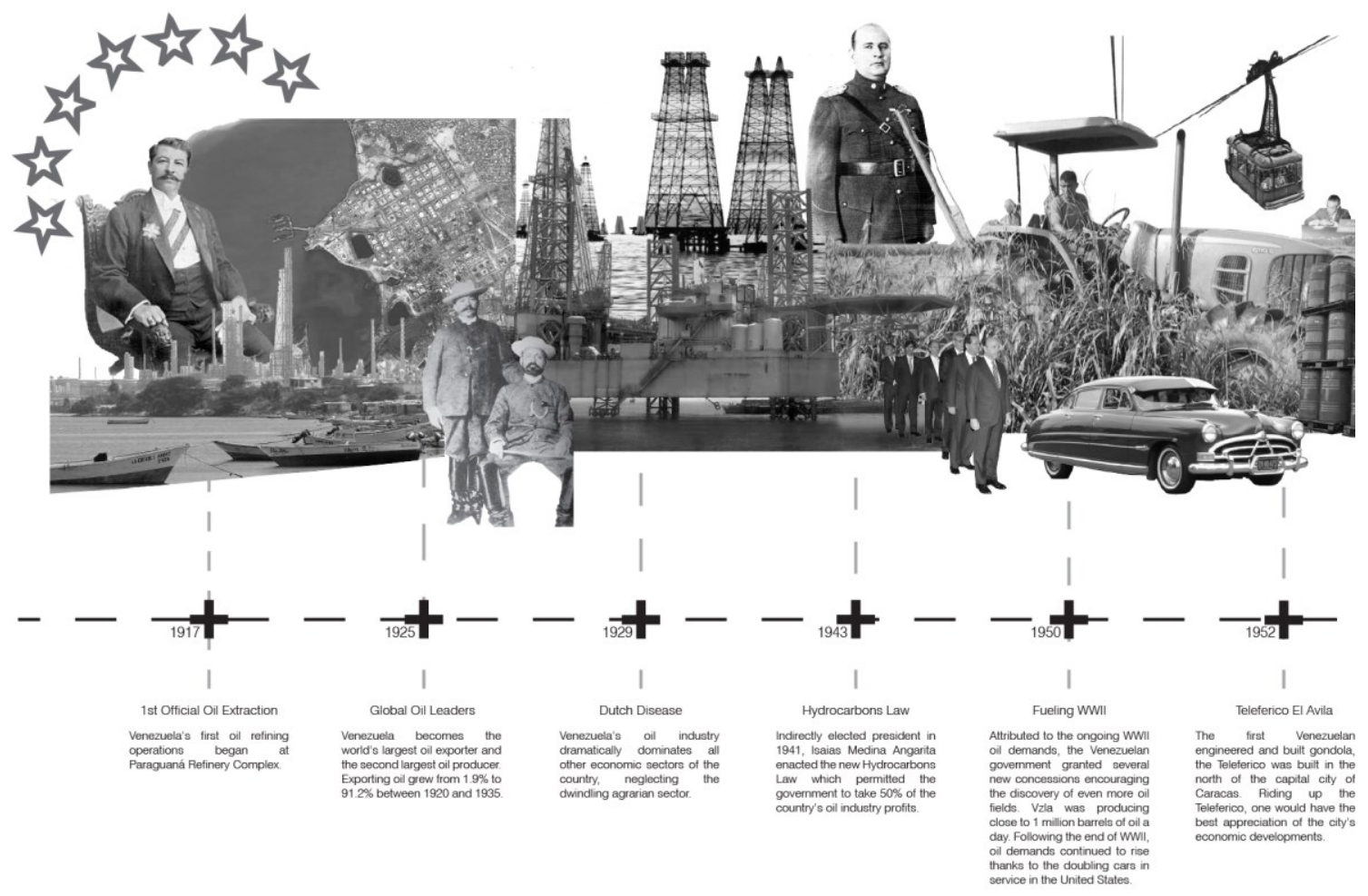




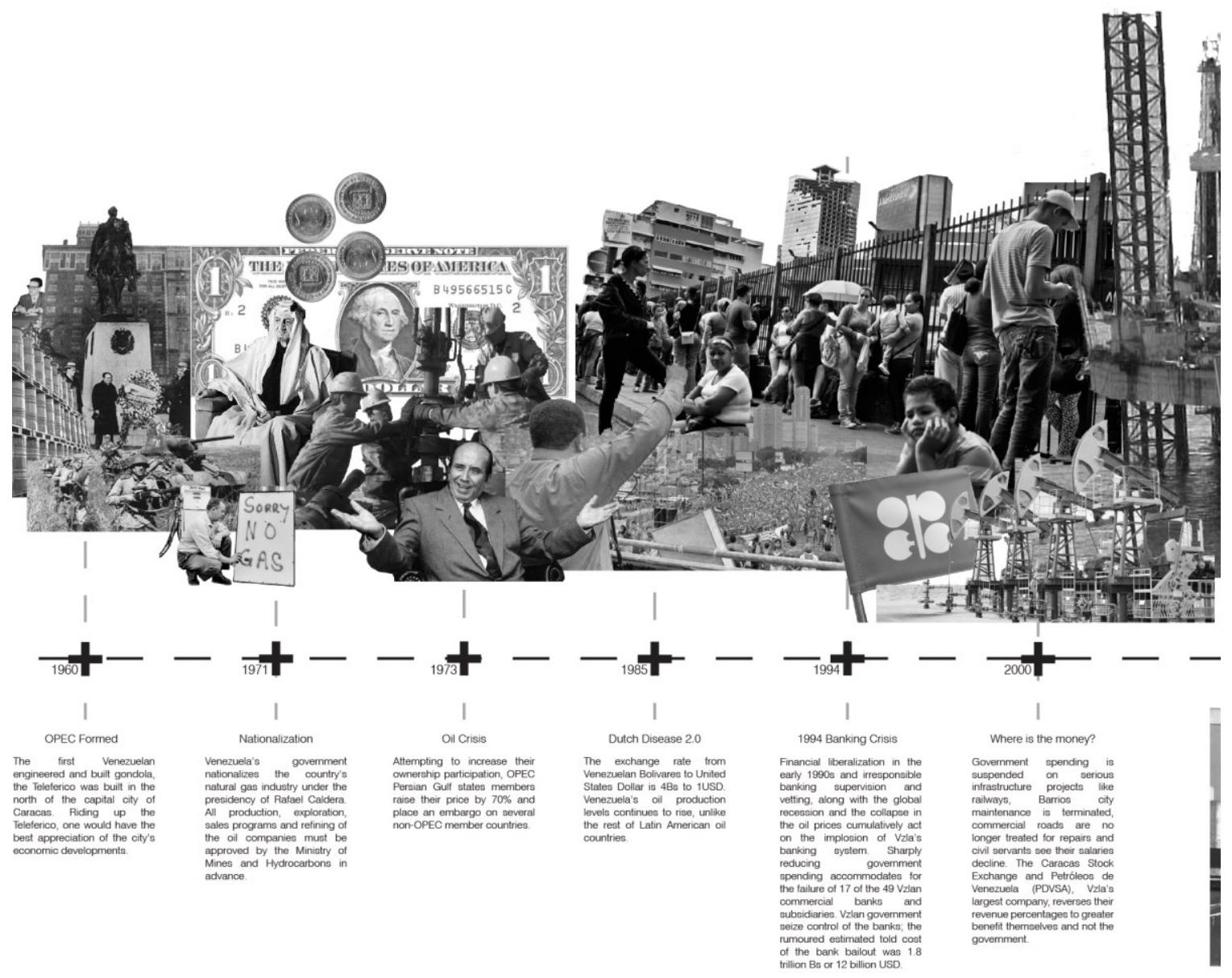




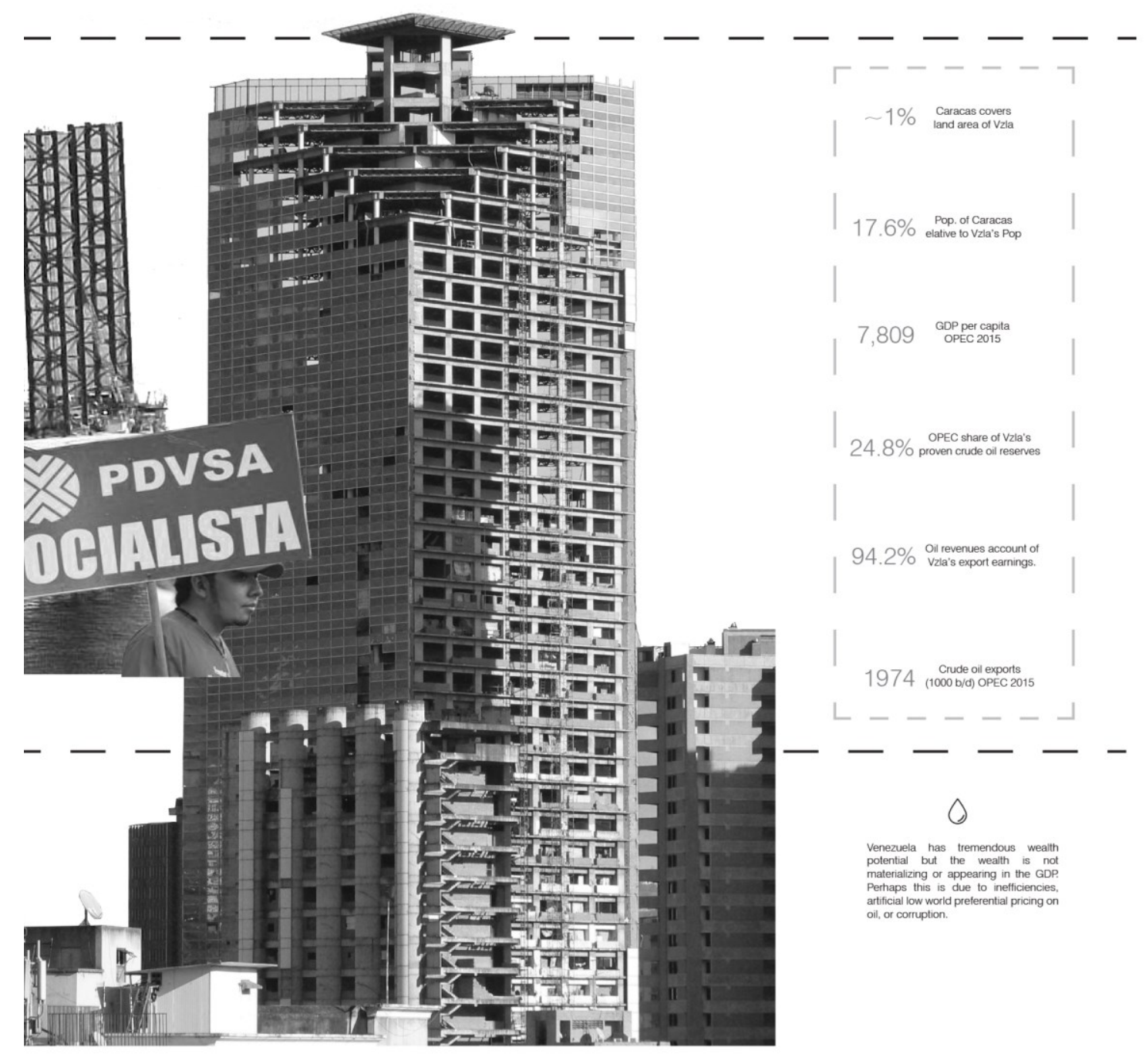




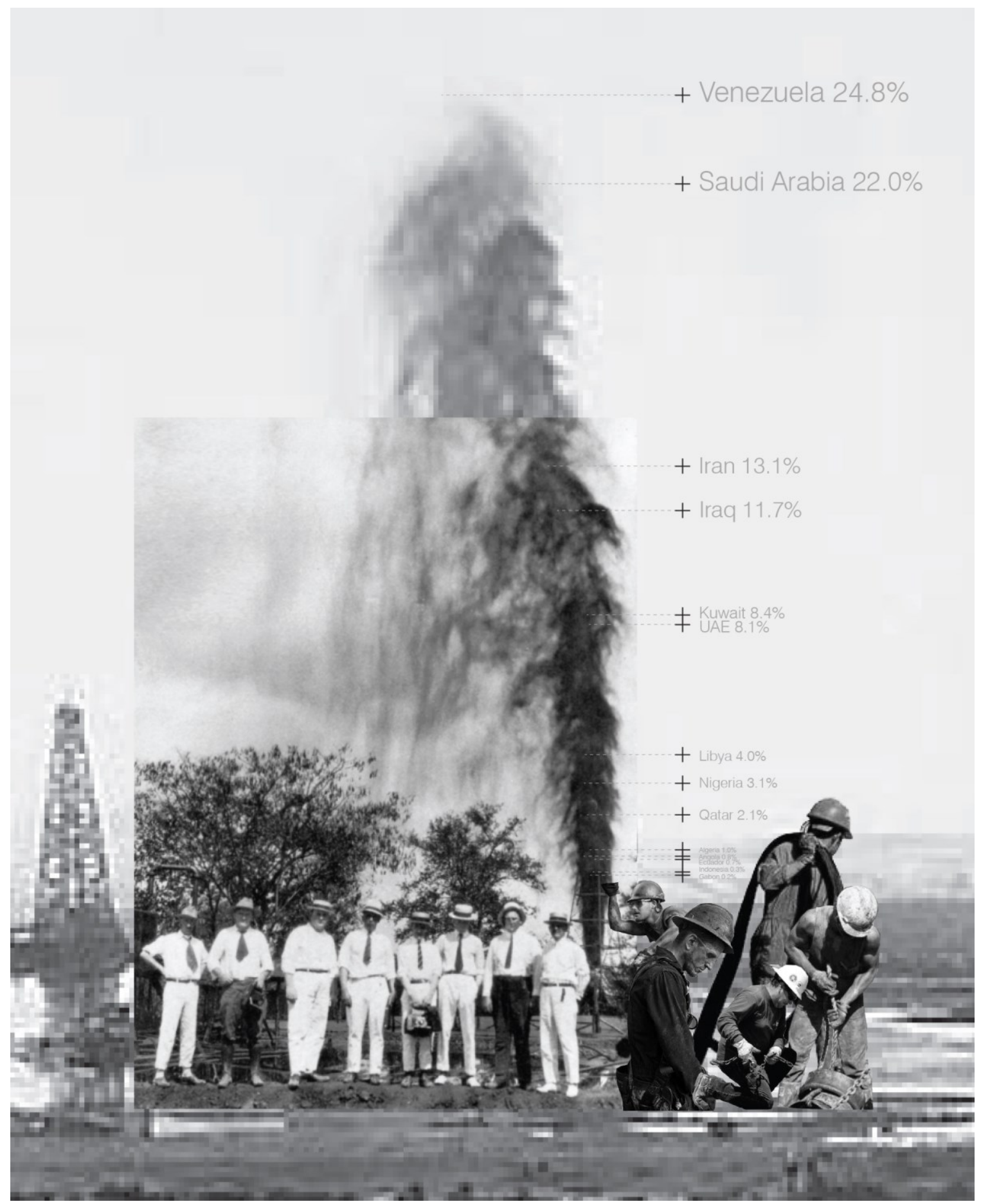

Figure 1-3: Oil Gusher

Centered in the drawing is a photograph of Venezuela's first Oil gusher, and the background drawing is contemporary oil gusher and its labour. Original author. 


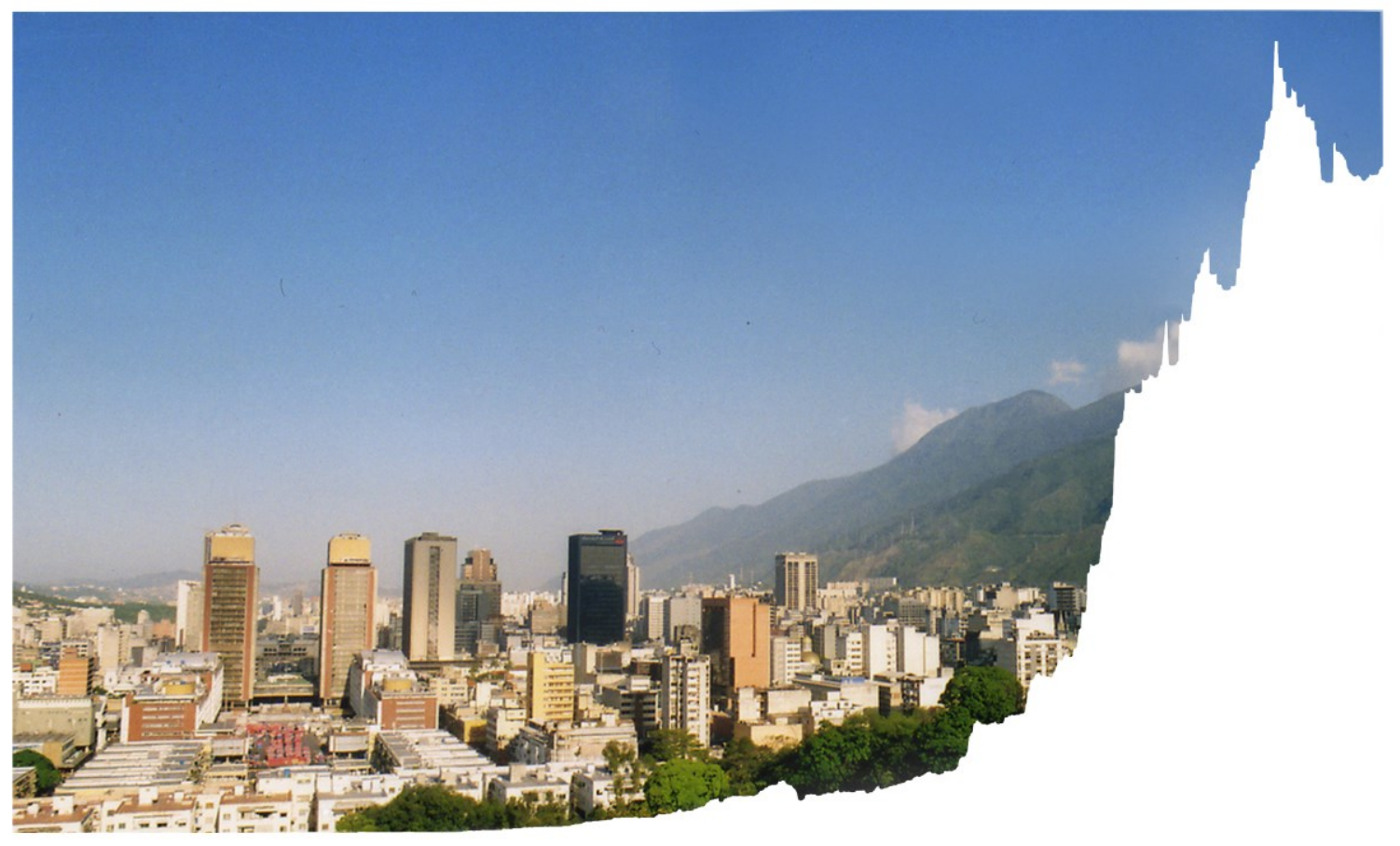

Figure 1-4: Piano Noble \& Inflation

The colourful skyline image of Caracas and its proximity to the Avila Mountains juxtaposed in this drawing by the negative space. This negative space is the Inflation graph, as can be seen on page 32. Original author. 


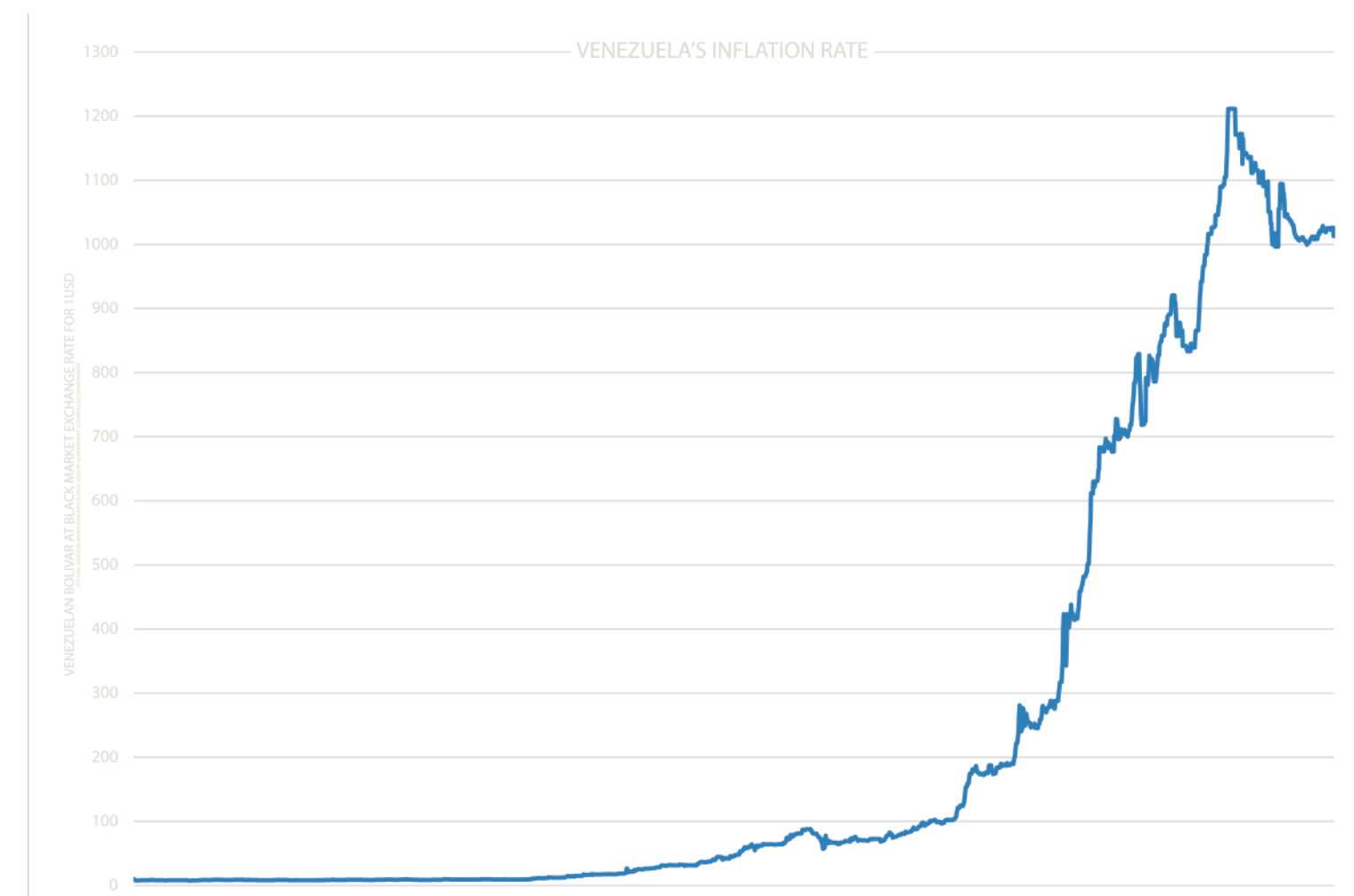

Figure 1-5: Venezuela's Inflation Rate

On March $28^{\text {st }}, 2017$, the exchange rate was 3063.18 Bs to 1 USD. ${ }^{30}$ Original author.

30 DolarToday.com. "Noticias De Venezuela Y Dolar Paralelo." DolarToday. DolarToday Publicacion, 28 Mar. 2017. Web. 28 Mar. 2017. 


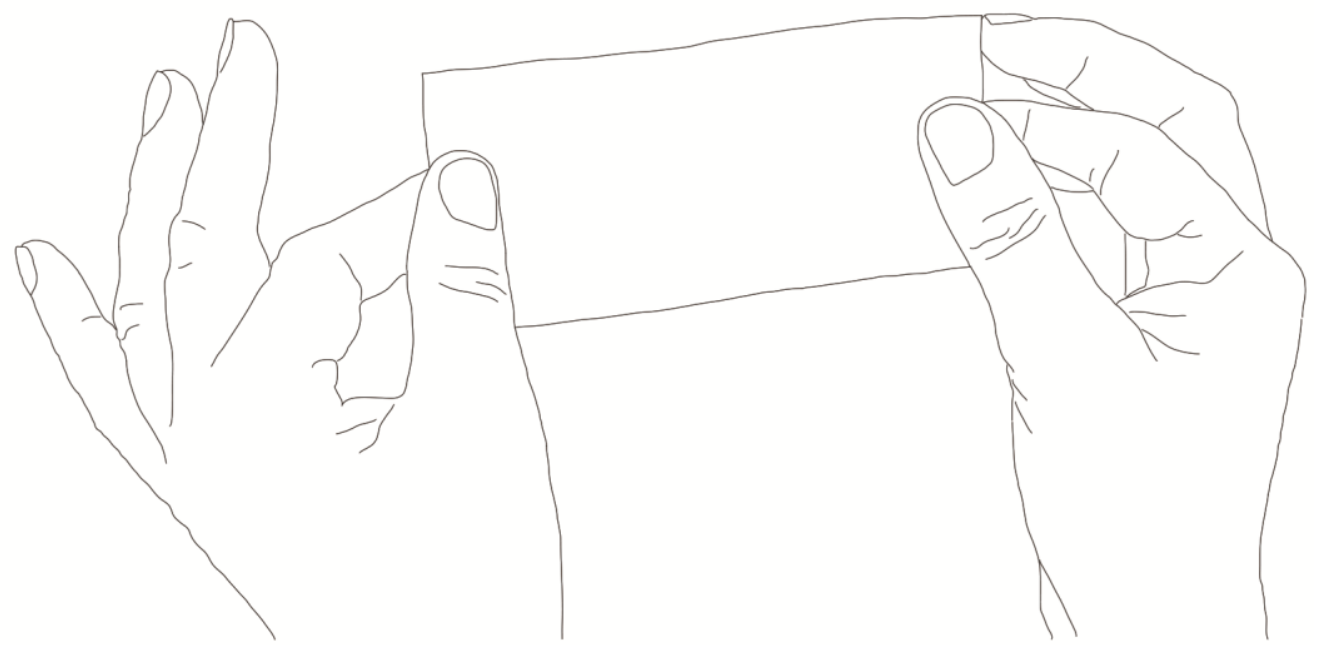

Chapter 2: The City in the Currency 


\section{Bank Note Authenticity}

As of January 1st, 2008 the government will begin to circulate the new family of banknotes and coins. To recognize its authenticity are the following security features:

\section{Touch-Sensitive}

Paper: banknotes are made with security paper: its texture is firm and sturdy. The paper used for banknotes does not have any similarity to regular paper.

Embossing: banknotes have special marks for the visually impaired, as well as the incorporated sensorial feel of the ink on the banknote (Figure 2-5).

\section{Visual}

Watermark: an almost transparent image that is seen clearly on the banknote when held to light. The mark represents the face of the historical character that is identified on each banknote (Figure 2-1).

Perfect Record: on the obverse and the reverse you can see an image that is completely identified and exactly matching when viewing the banknote against light.

Security Thread: at first glance looks windowed (broken stripes), but the contrast with the light is full and continuous. Also, this thread contains small texts identifying the banknote (Figure 2-3).

Microfibers: are small lines of colours scattered around the bank note.

Optically Variable Ink: when turning the bank note or tilting it, there is a figure that changes colour by the incidence of light. 
Fluorescent Effect: with the use of ultraviolet lamps, fluorescence observed on the bank note. ${ }^{31}$

31 Banco Central De Venezuela. "Bolivar Fuerte: Una economia fuerte, un Bolivar fuerte, un pais fuerte." Banco Central De Venezuela. Pamphlet. 2007. Acquired 2007. Translated in English by author. 


\section{Bank Note Modified}

On January 1st, 2008, the Venezuelan Government and their banks circulated a new family of bank notes and coins. This economically recognized currency was to be a symbol for Venezuela's strength and independence as a nation.

The three modified currency drawings speak on two levels: the superficial value of the bill, and the subtle effects depicted in the modification of the bill. The three bank notes that have been modified are the $5 \mathrm{Bs}, 10 \mathrm{Bs}$ and the $20 \mathrm{Bs}$. The obverse of each bank note is portrait formatted whereas the reverse is landscape formatted.

5BS.

The reverse of the 5 Bs features a Giant Armadillo and baby Armadillo roaming the Venezuelan Prairies. I modified the rough protected shell backs of both Armadillos to instead feature the Barrios, or typical slum housing of Caracas. The cube blocking orientation and planning of the Barrios not only resembles the original bank note design, but suggest a subtle implication of the housing crisis and crime rates in Caracas and Venezuela at large (Figure 2-2).

\section{BS.}

The reverse of the 10 Bs features the Harpy Eagle, famous natural falls in Venezuela (Ucaima, Tepuyes Venado and Kurun) and the Canaima National Park. 
The Harpy Eagle positioned in the center of the bank note stares off into the distance in a proud stance. On its right wing, prominently featured on the bank note, are the empty shelves of a grocery store. The country wide shortages of daily supplies like flour, milk, eggs and toilet paper are best substantiated by the long and hopeless queues of people snaking around grocery and department stores with next to nothing on their shelves (Figure 2-4).

\section{BS.}

Two Hawksbill Sea Turtles are depicted in the foreground and the mountain of Macanao in the background. According to IUNC, the Hawksbill Sea Turtle is critically endangered..$^{32}$ On the back of the two Sea Turtles - who are seemingly floating in the sea - are images of oil spills out at sea. Difficult to notice from afar, the modification reveals a subtle, but honest truth about corruption and instability of the Venezuelan oil market (Figure 2-6).

\footnotetext{
${ }^{32}$ Henry, Leigh. "Hawksbill Turtle." WWF. World Wildlife Fund, n.d. Web. 31 Mar. 2017.
} 


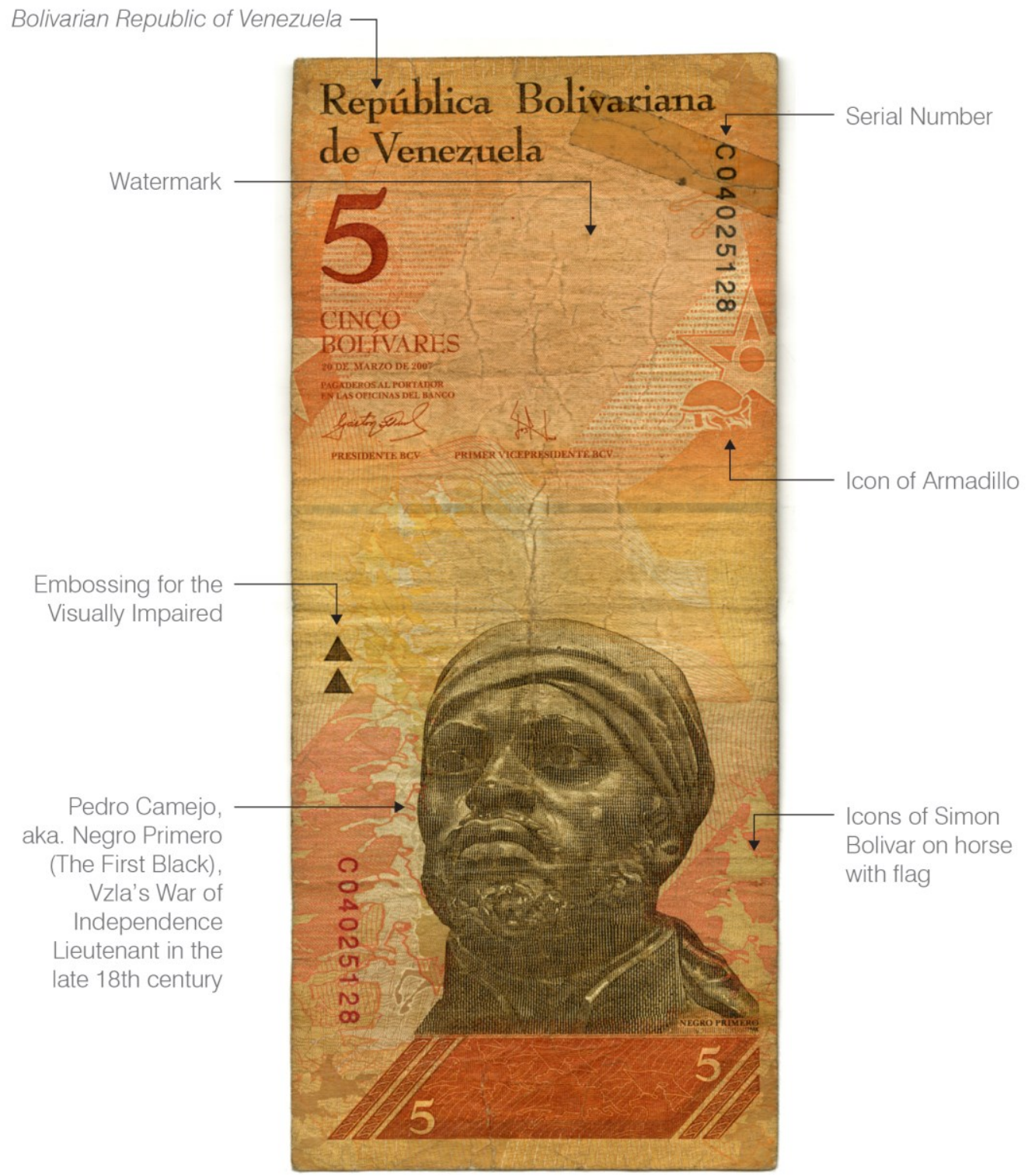

Figure 2-1: 5 Bs Recto

Annotation by original author. 


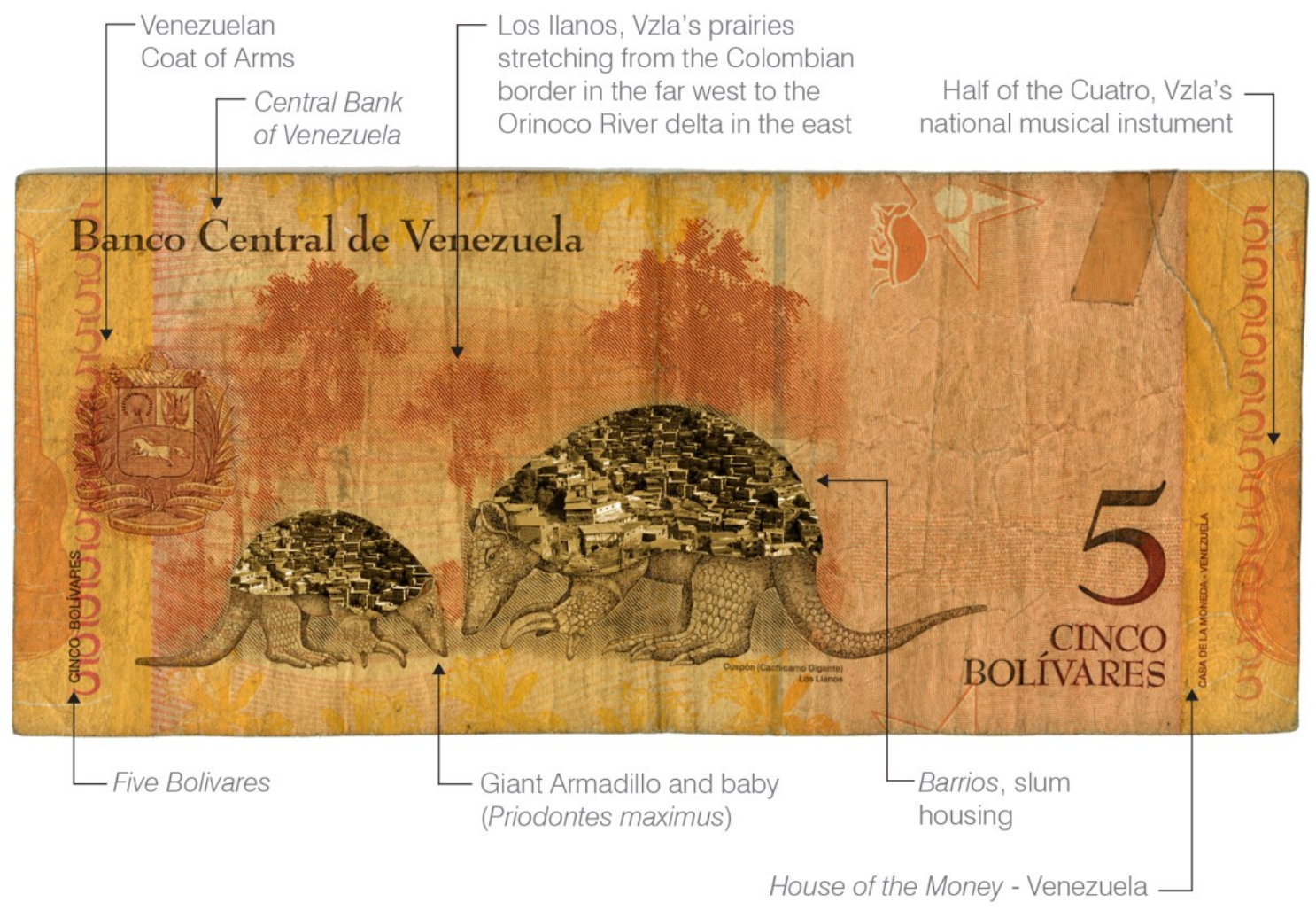

Figure 2-2: 5 Bs Verso

Annotation by original author. 


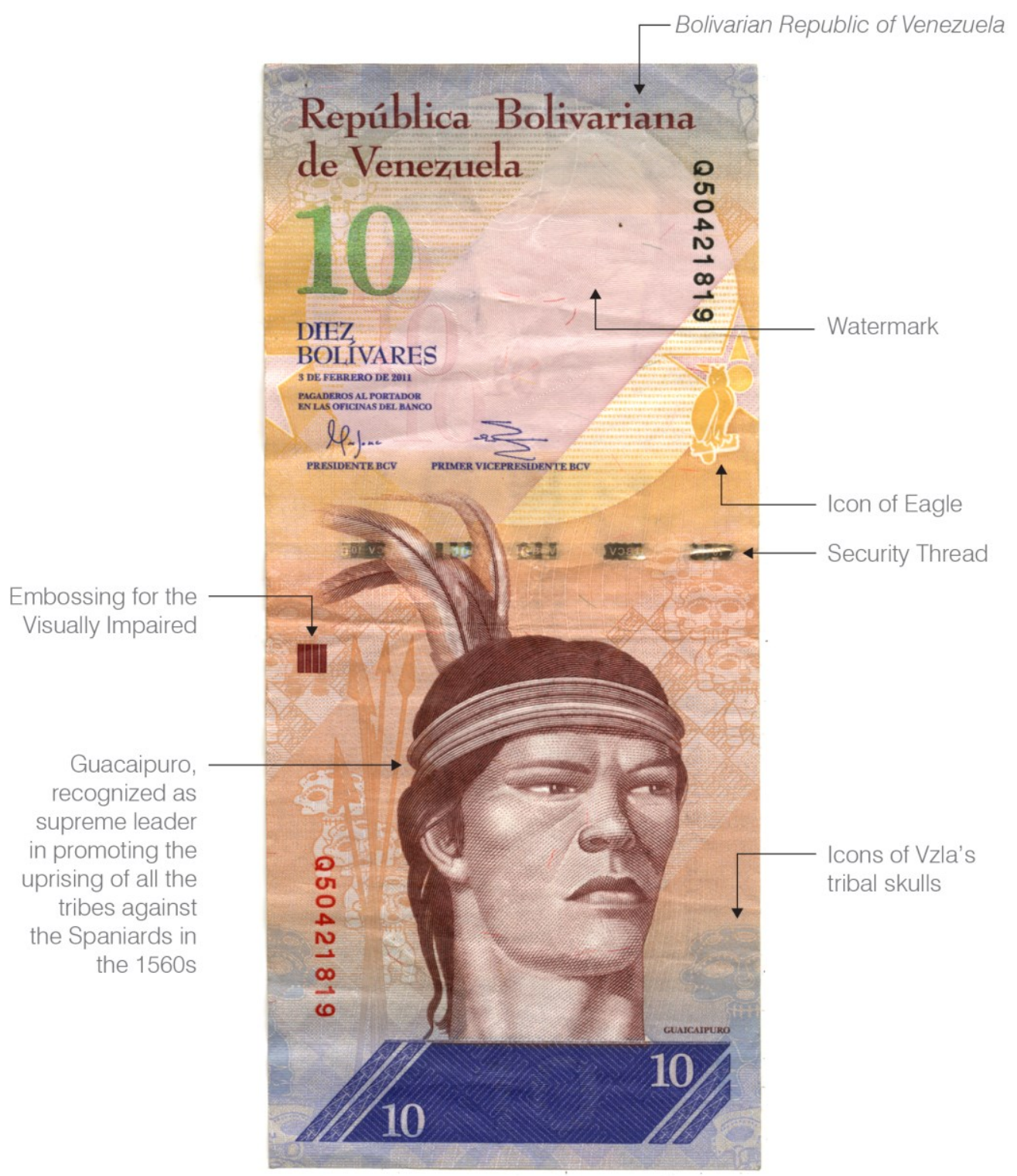

Figure 2-3: 10 Bs Recto 


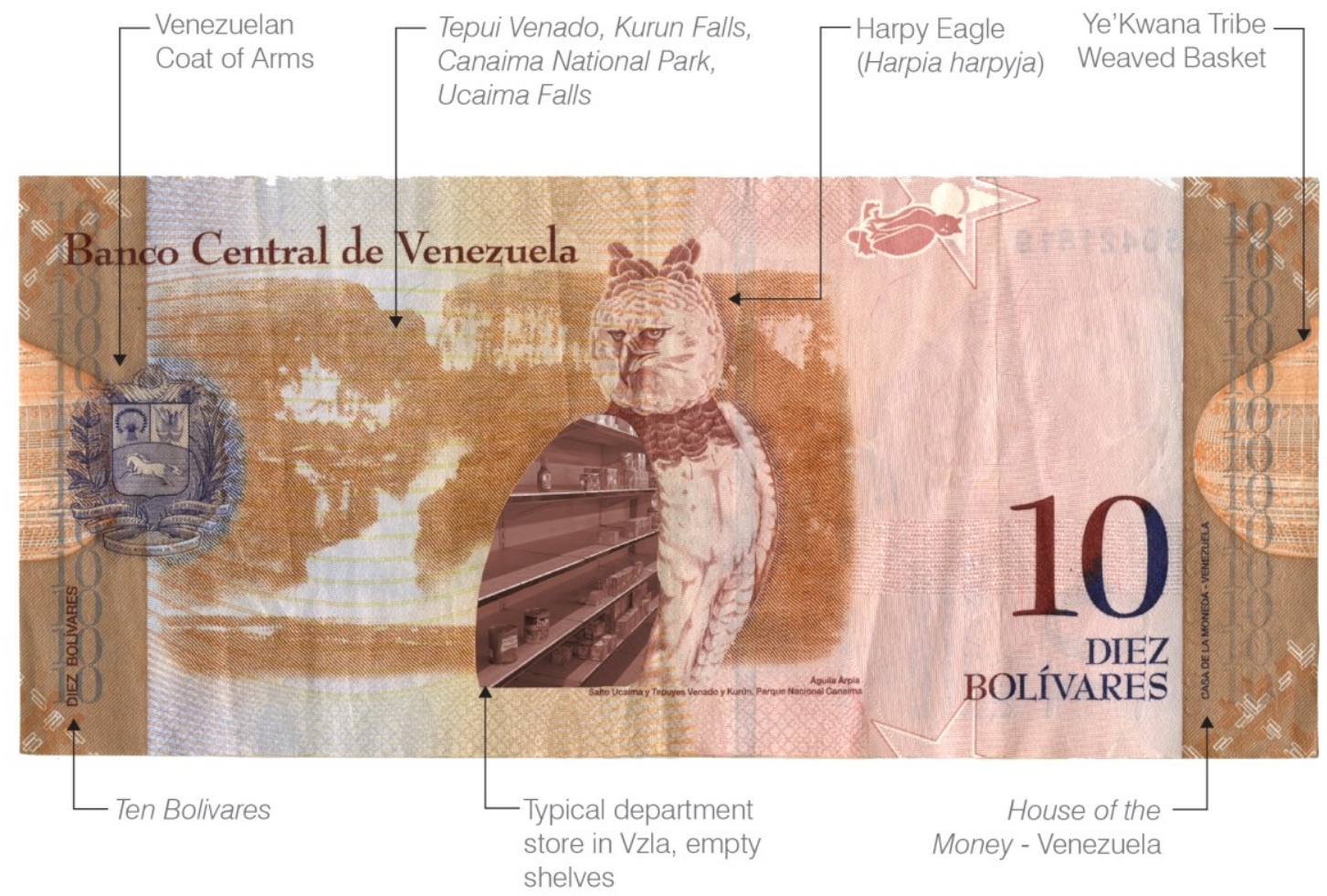

Annotation by original author.

Annotation by original author.

Figure 2-4: 10 Bs Verso 


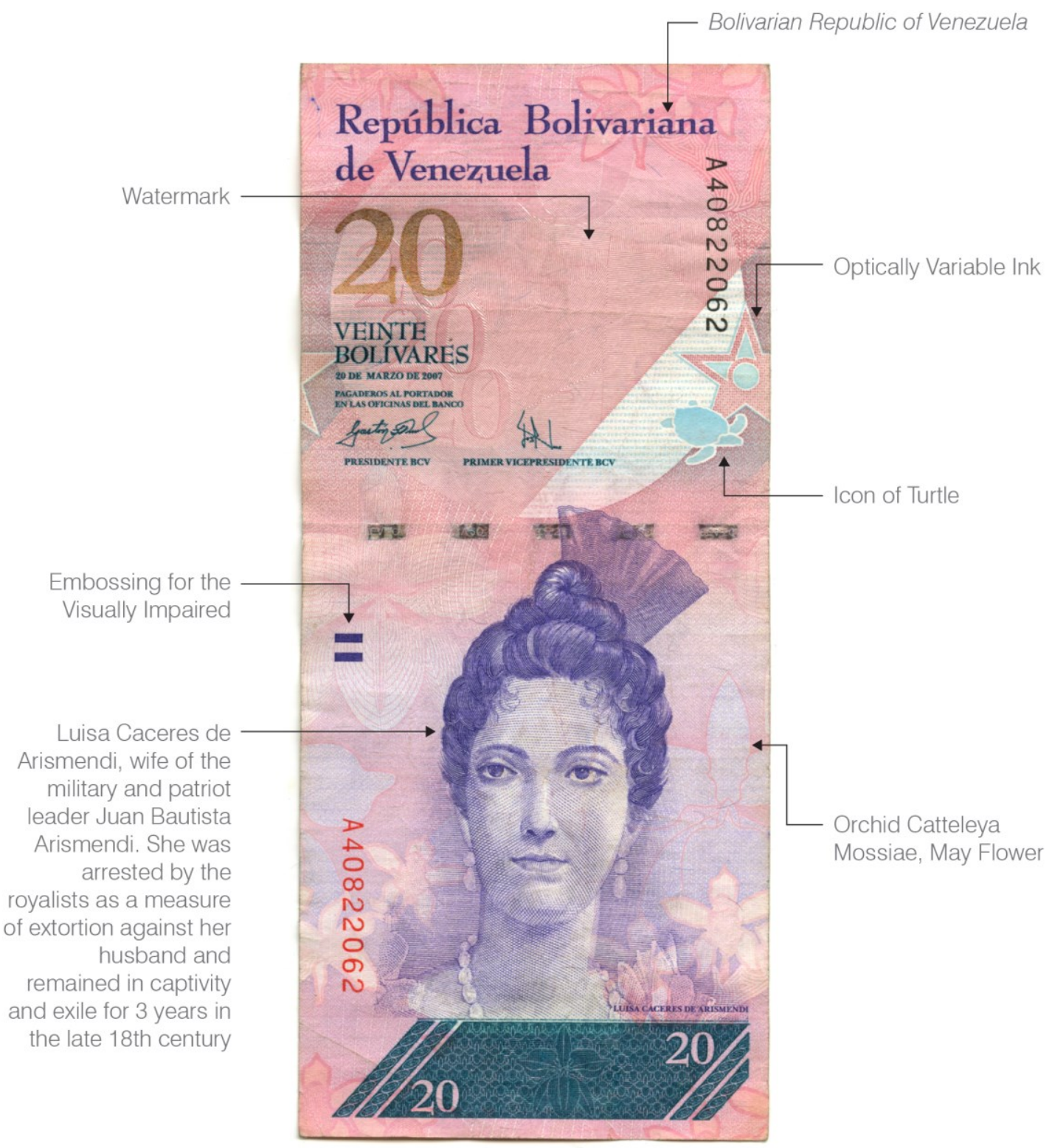

Figure 2-5: 20 Bs Recto

Annotation by original author. 


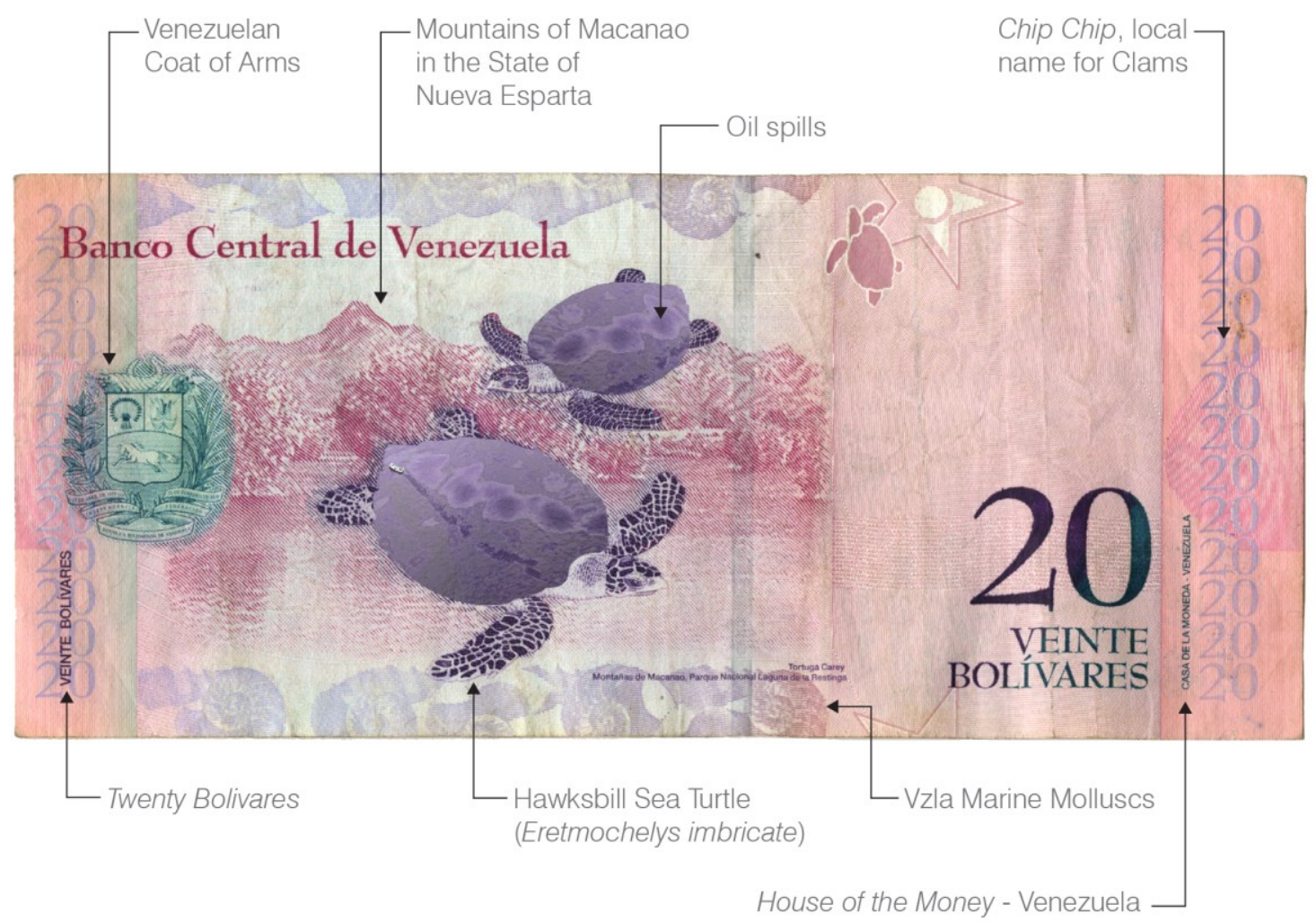

Figure 2-6: 20 Bs Verso

Annotation by original author. 


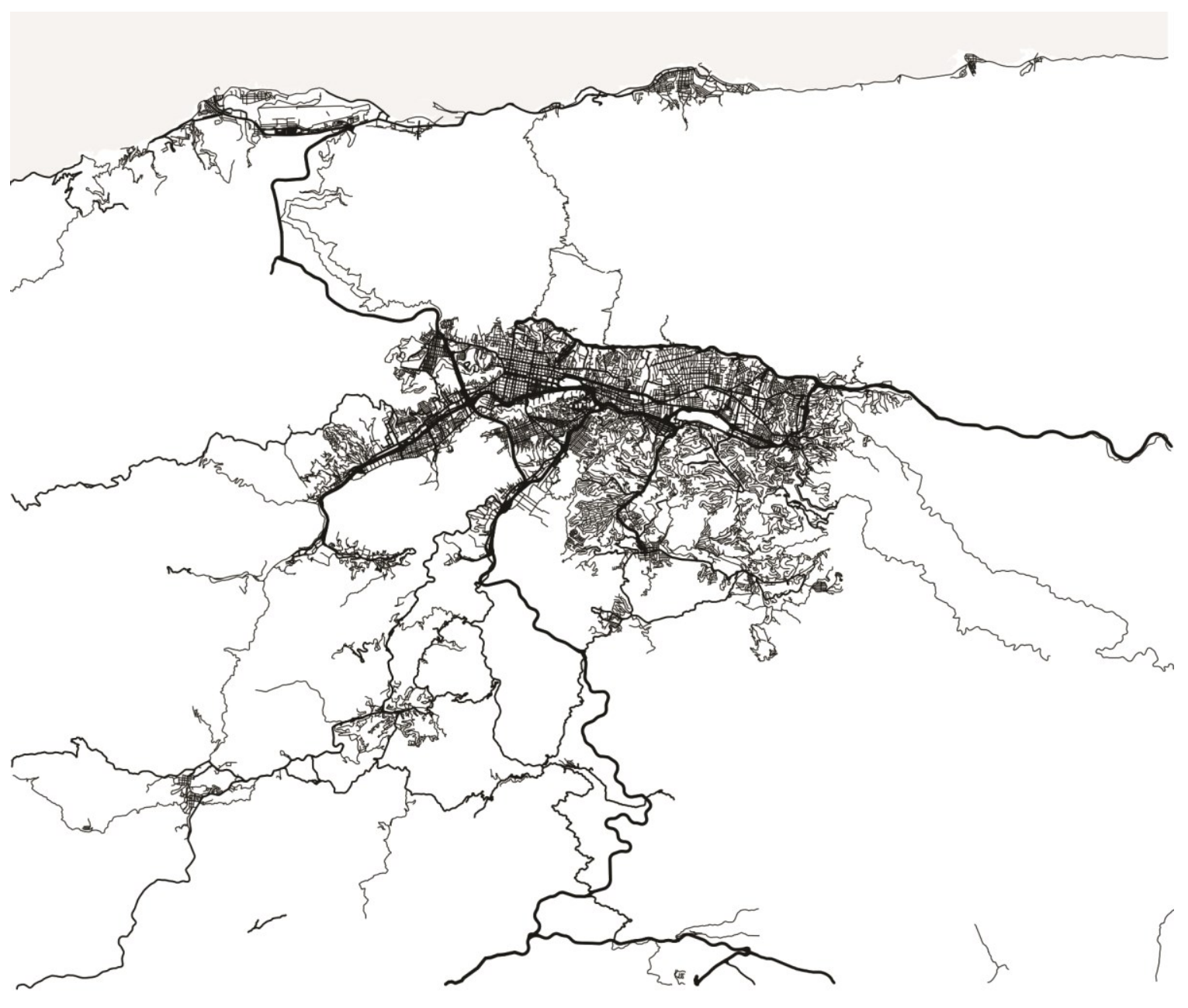

Figure 2-7: Plan of Caracas

This drawing illustrates the infrastructural nature of Caracas. Original author. 


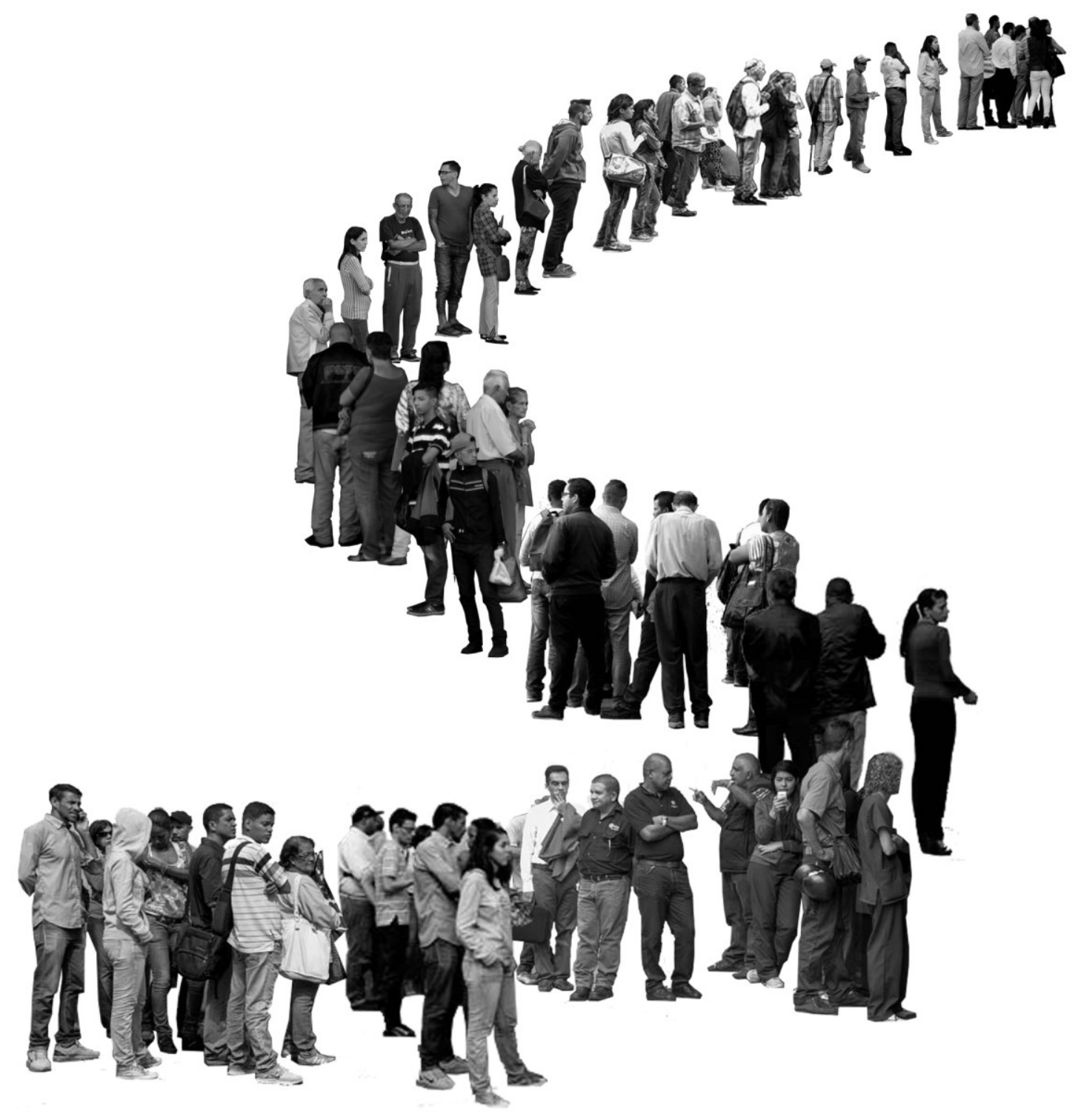

Figure 2-8: Queues

This drawing illustrates the haplessness of queues, with occasional moments of activity. 


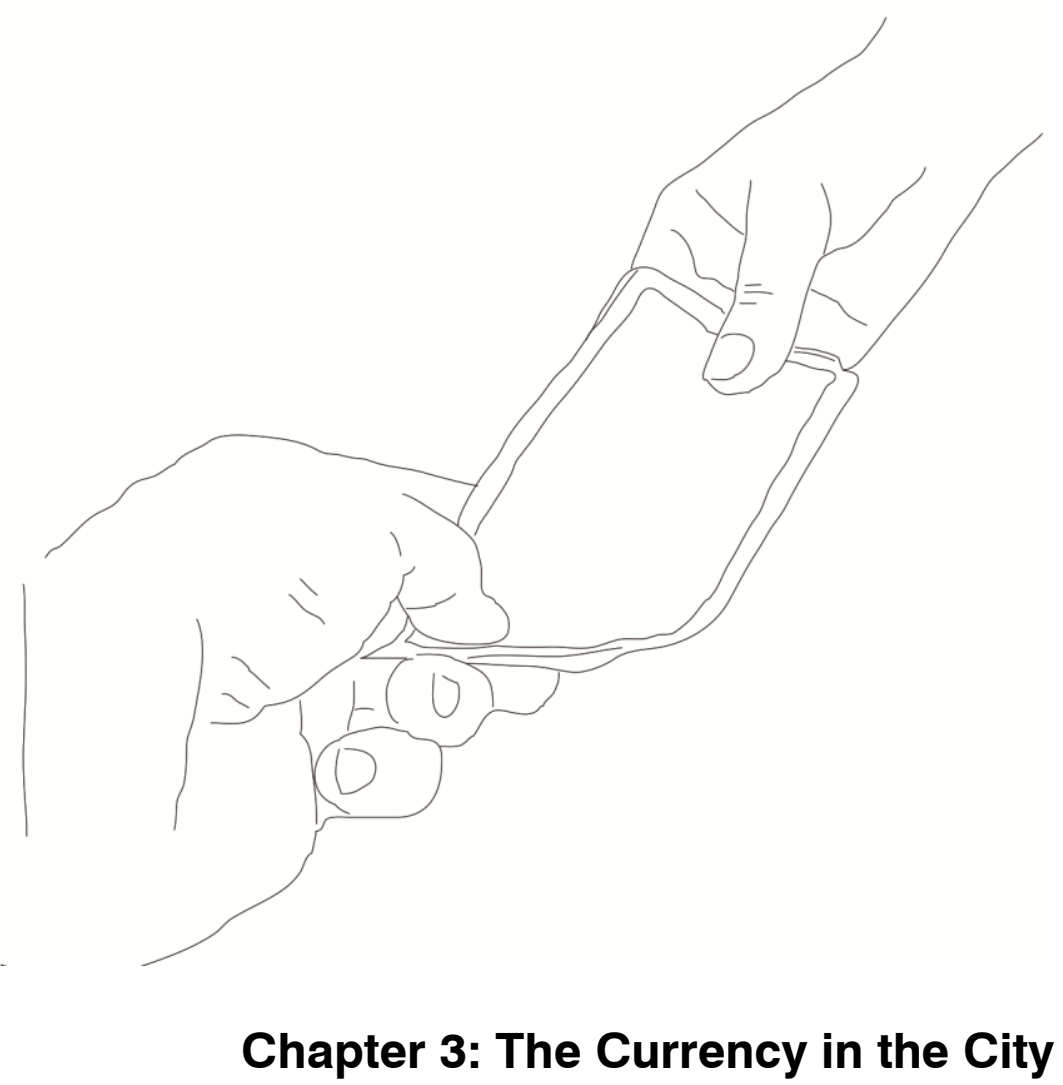




\section{Grey Market}

The only affordable way to exchange Bolivars to United States Dollars is through the 'Black Market,' a practice that is only partly spatial, illegal exchanges of money between hands. This market is located in back rooms of the barrios, and in other 'underground' venues around the capital city. But the Black Market cannot be accurately mapped. Myriad facets of Caracas' culture are corrupt: from the manipulation of the price of oil excavated form the earth to restrictions on the flight paths of cargo planes in the sky, the Black Market is a ubiquitous element in the landscape.

Citizens of Caracas pay as much as 17 times more for basic staples like milk and eggs in the Black Market grocery kiosk than in a White Market sanctioned grocery store. ${ }^{33}$ Why? Because there is simply no food at the White Market sanctioned grocery store. Though price tags exist, the shelves are empty. So the

\footnotetext{
33 Tong, Scott. "A Day out at the (black) Market in Venezuela." Marketplace. Panama Post, 3 Apr. 2016. Web. 27 Mar. 2017.
} 
Black Market kiosks operate in the shadows, providing basic goods at impossibly inflated prices.

The 'White Market' exists in a sanctioned exchange venue. It is the licit government controlled exchange spaces like banks or ATM stations. Their perimeters are clearly articulated in the city plan and business districts.

If the sanctioned and legal exchange venue of the White Market is corrupt and its inflation rate too inaccurate, and the unsanctioned and illegal exchange venue of the Black Market was too cruel with its abhorrent exchanges rates, then how can we reveal exchange value as a function of spatial networks, and at shifting scales? We build a bridge, a new venue, a "Grey Market."

These proposed architectural frameworks are equally hidden, perhaps more so. But in contrast to the Black Market, the new Grey zone is designed to resist corruption, to fight inflation. It is designed to protect those who are currently deprived and excluded. 


\section{Security Techniques}

The security elements featured on the Venezuelan bank notes are tactile moments of a spatial dimension. The watermarks, security threads and embossing for the visually impaired are communicating techniques to an architectural realm. These techniques that have been applied to bank notes can be translated into spatial operations in the city. The bank notes circulate throughout the exchange systems, hiding their loaded clues in plain sight.

The brick walls lining the Barrios streets are canvases for water marks. Rain falls and wets the city's exterior surfaces, forcing the water mark on a specific building to present itself as the Grey Market location for the moment (Figure 3-3).

The empty shelves of the local grocery store collect dust on their white plastic surfaces. The technique of embossing for the visually impaired feature on the bank note is implemented on the shelves as a form of brail communicating the location of the Grey Market for the moment (Figure 3-6).

The serial number on the obverse of the bank note holds the key to the location of the Grey Market within its digits. Imputing the correct serial number at any pump at the local gas station will offer an address. This is where the Grey Market exchange venue is for the moment (Figure 3-9).

The information these security features hold is limitless; addresses, names, dates, co-ordinates, etc. Evolving from the security techniques on the economically worthless bank note, the Grey Market transcends an alternative space of exchange that is legal and that is not government organized. 


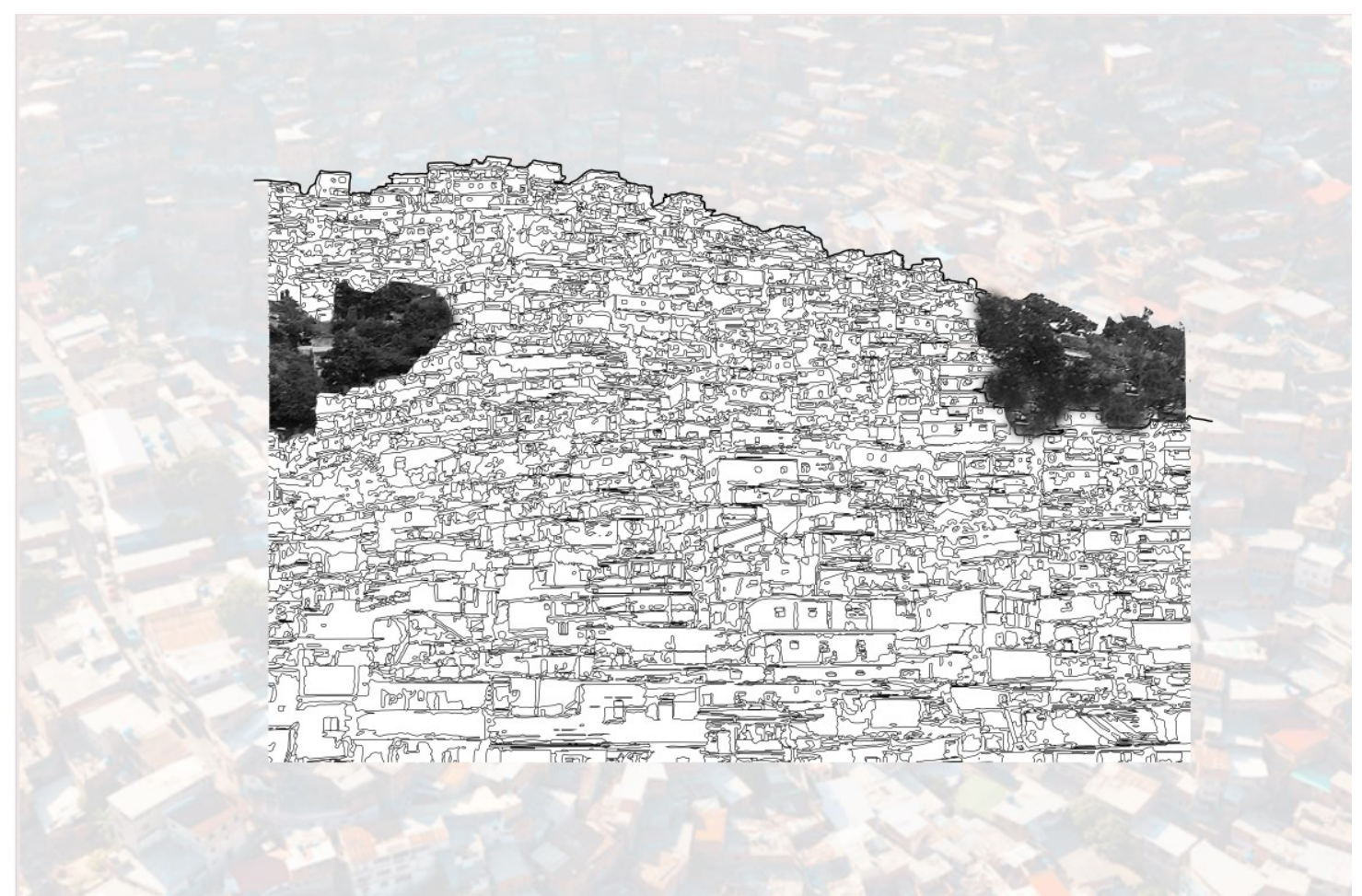

Figure 3-1: Barrios 


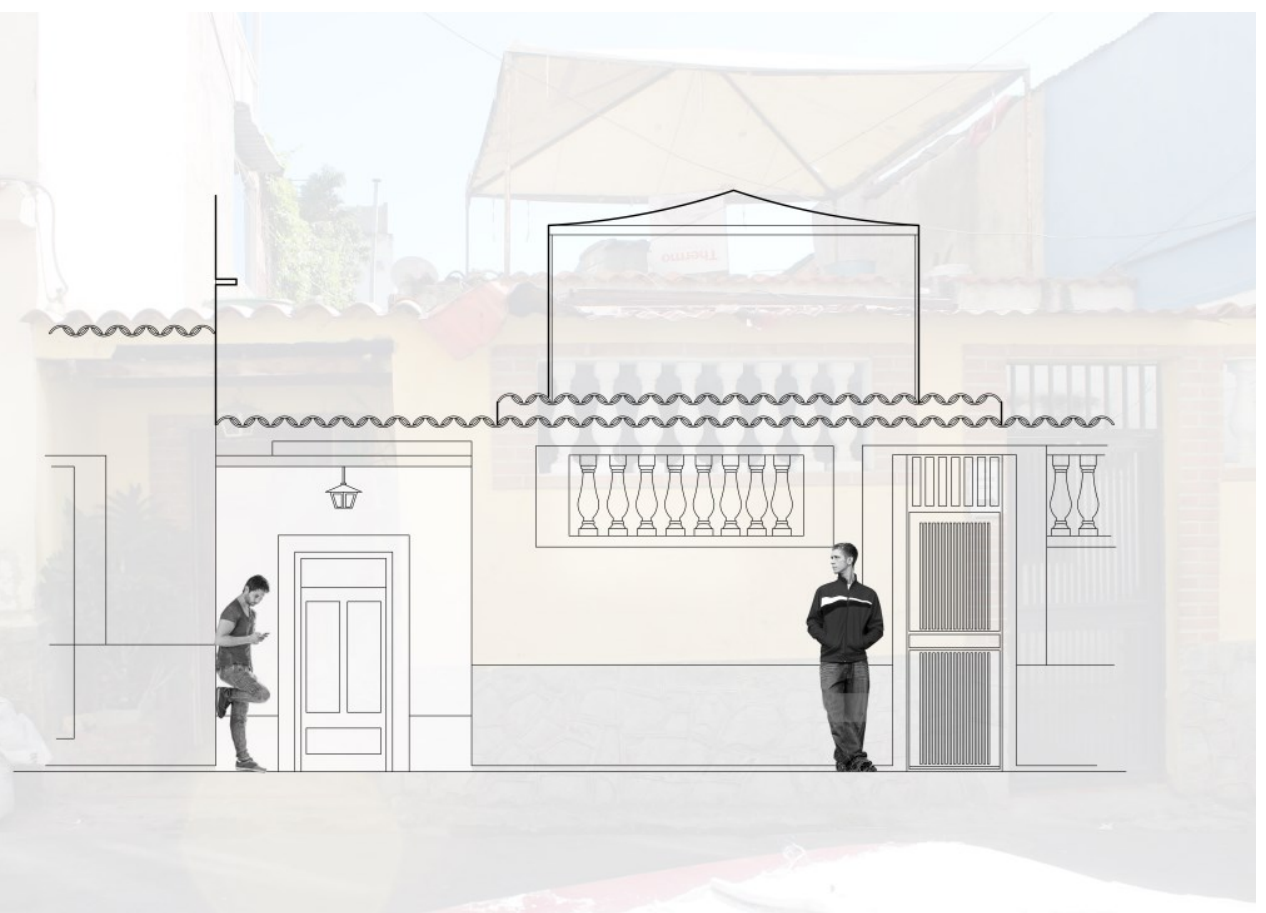

Figure 3-2: The Streets of the Barrios

An original photograph taken from my aunt's front door in her Barrio at sunset. Original author. 


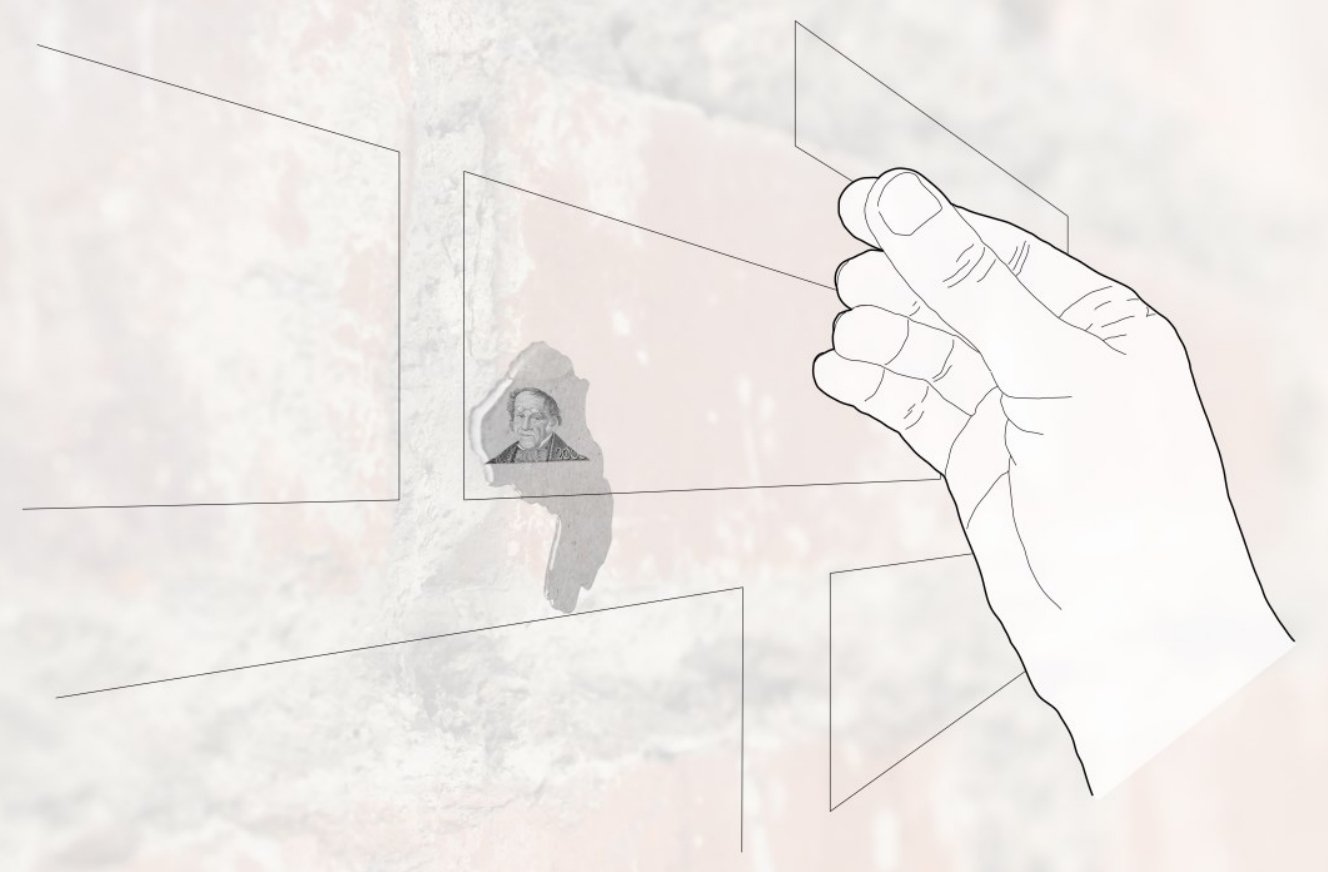

Figure 3-3: Watermark in the Barrio

This original photograph lends itself to the possibilities of a watermark indicator for a Grey Market. Original author. 


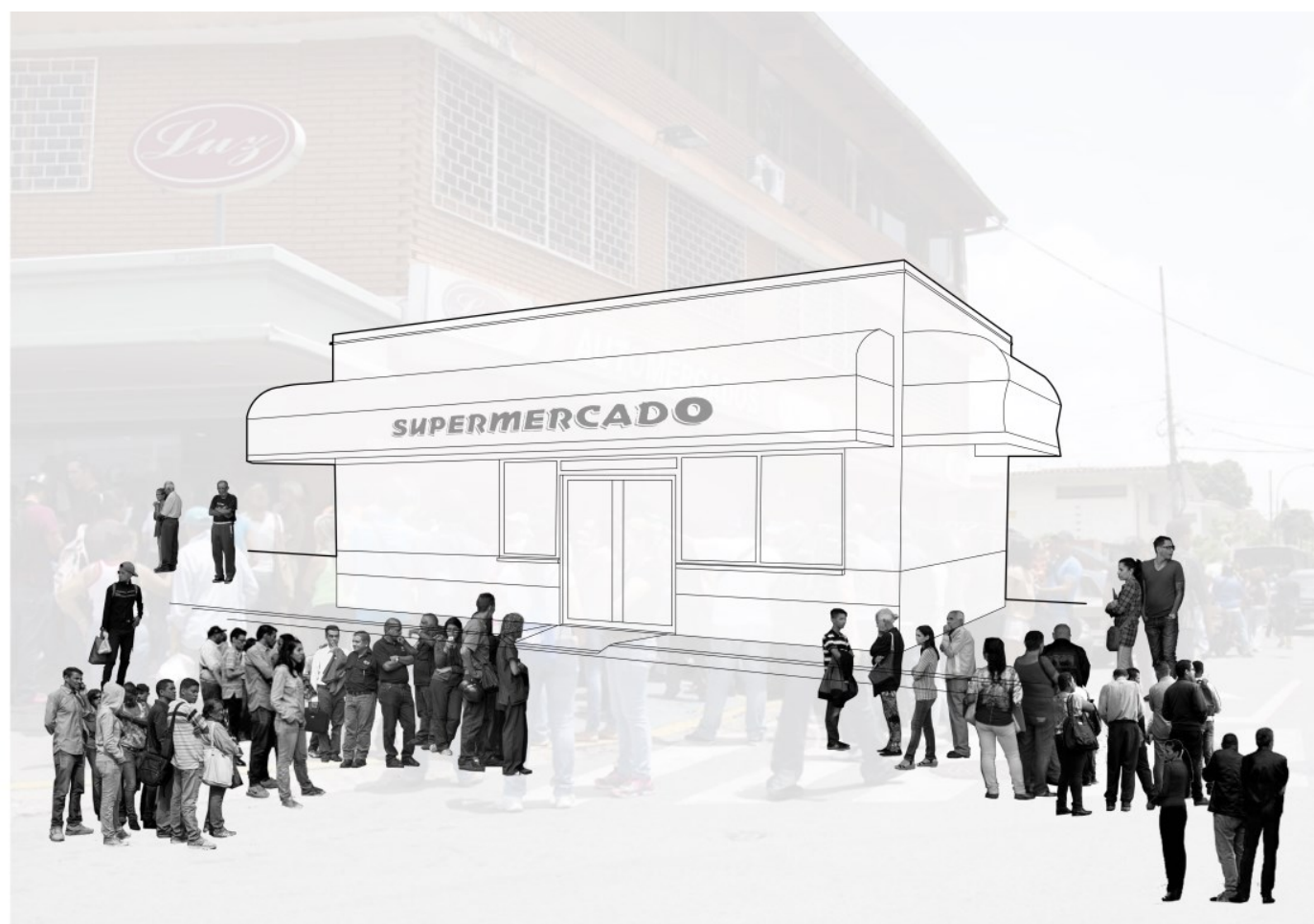

Figure 3-4: Grocery Store Queue 


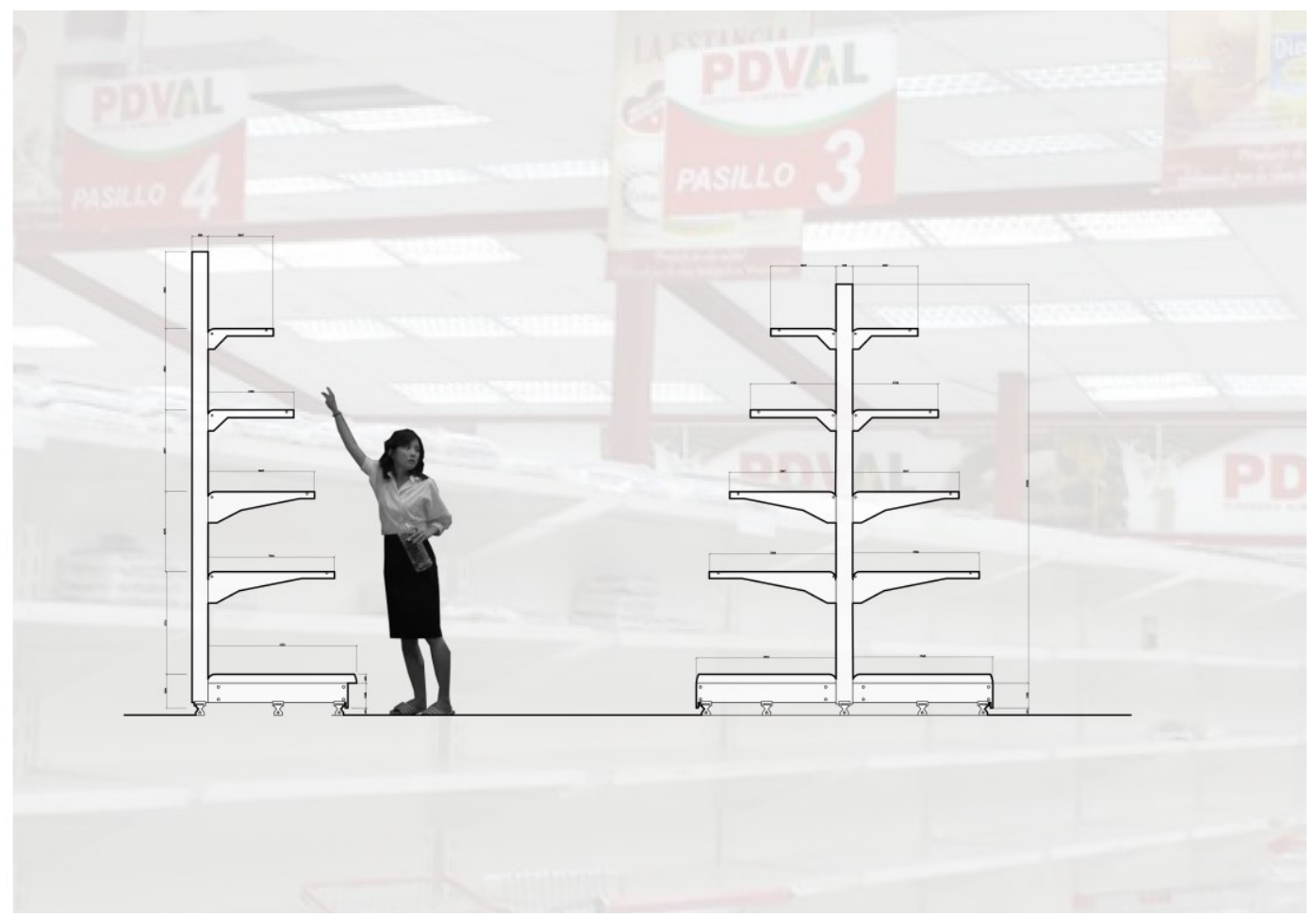

Figure 3-5: Inside the Grocery Store 


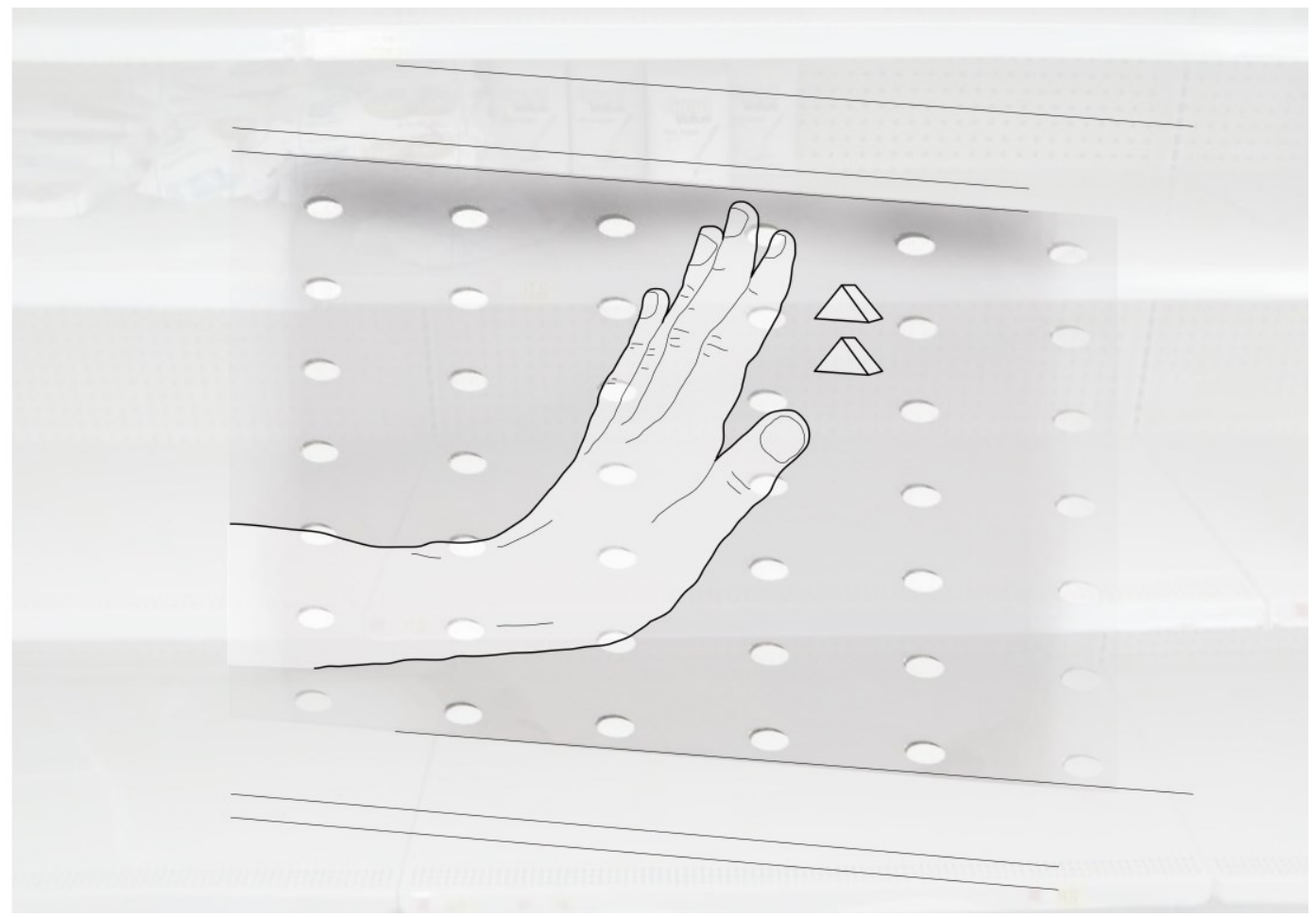

Figure 3-6: Empty Grocery shelves 


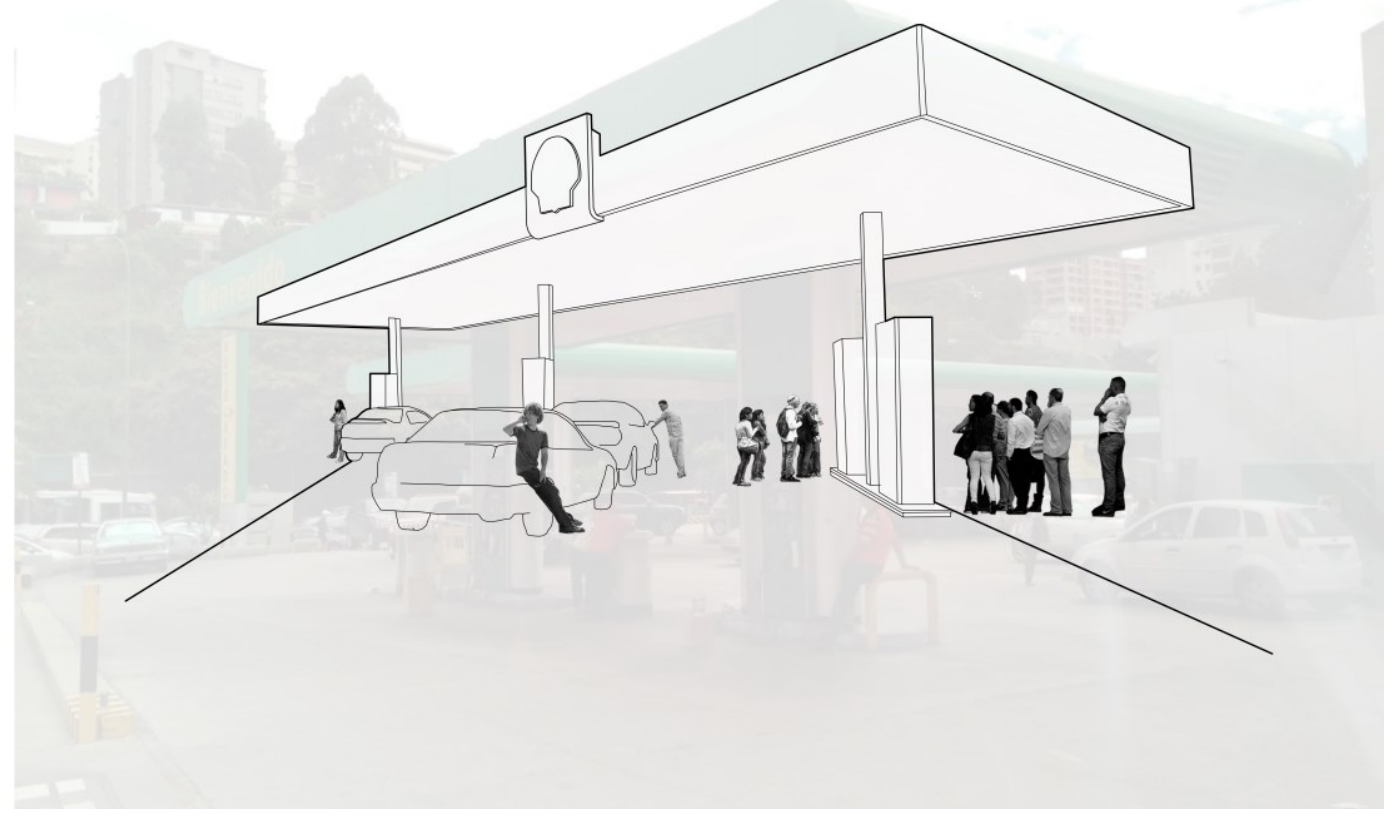

Figure 3-7: Typical Gas Station 


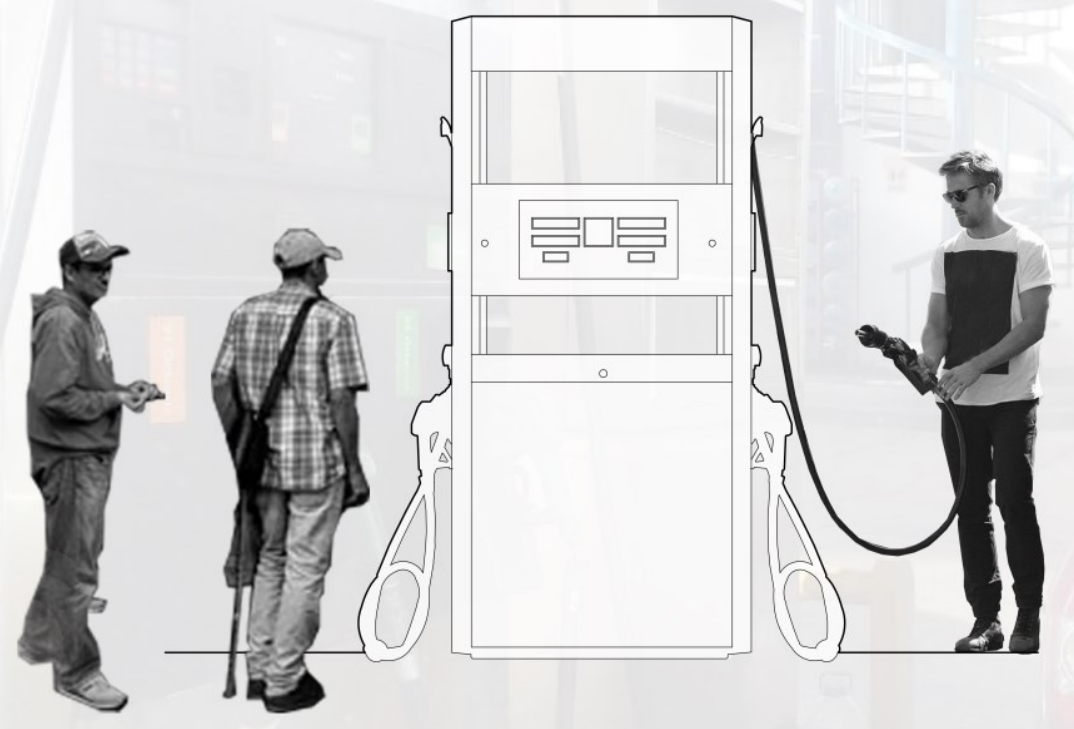

Figure 3-8: Gas Pump 


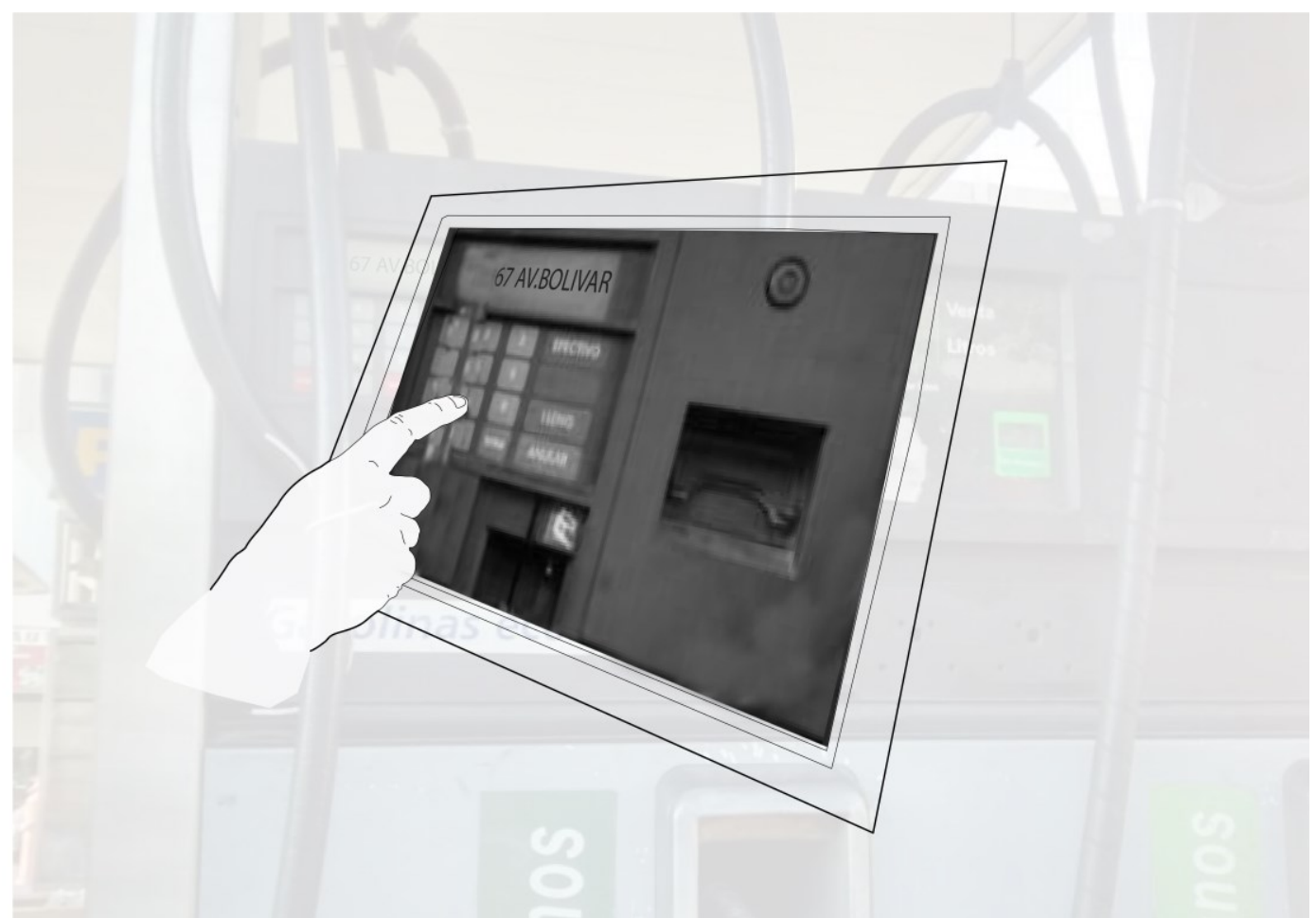

Figure 3-9: Gas Pump Input 


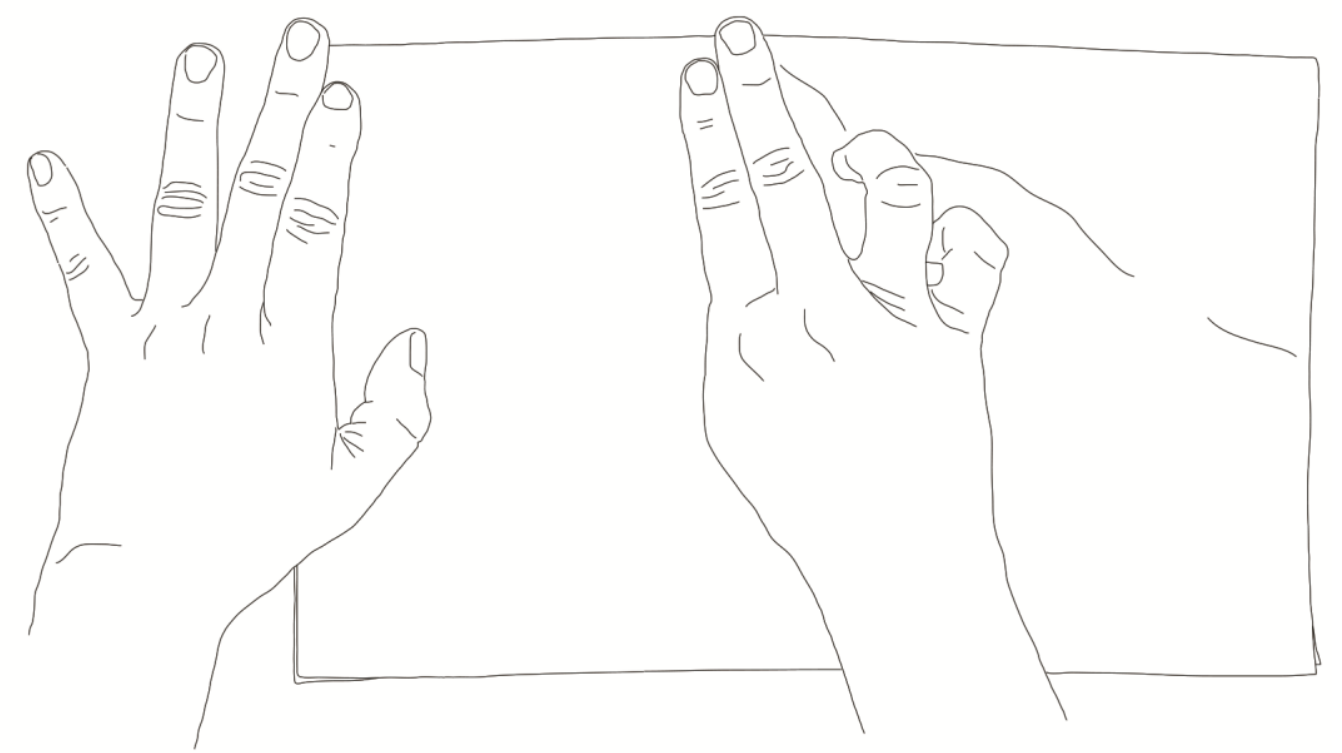

Chapter 4: The Currency in the Book 


\section{The Book and the Desk}

Whether designing a room, a building, a city or a landscape, the question "what is the spatial implication with the work," is ever present. Is there a material reality of some sort? Is this tectonical? Is this morphological? Is there programmatic reality? This thesis dovetails into interventions that relate to the spatial and urban conditions when and where exchange happens in the city. Conceptualizing the thesis as an art based series of interventions that are still absolutely spatial, are that are still tectonic, that have particular morphologies that have particular programmes attached to them, are the architectural interventions.

At the broad scale, conceptually, the postcards were a way of remaining in contact. Also a way of informing and exchanging information. They are currency of sorts; they are a currency of familiarity, of currency of empathy, of compassion, of memory and of family. The postcards take Caracas and bring it to Ottawa, and take Ottawa and actually shifts it to Caracas. These displacements happened irrespective of time, distance and place in the exact same what digital currency works. Given the inevitability of the obsolescence of tangible currency, do the potential spaces where we exchange negate? Will everything simply be on Amazon?

The Black Market spatial implications of getting paid under the table, intimate spaces, subtle exchanges, paralleled with the White Market's physical separations, the interfaces, and the exposed counter surface. The Grey market 
residing between the licit and the illicit use of money. These are all spatial realities, but can they be relatable at a shifting scale?

Through a series of speculative drawings that are either representational, collage, photomontage based, assembly based, the spatial implications of the Grey Market are explored in a similar fashion as the hacking of the original tangible currency, bound together in a book.

The thesis is the book - a manuscript of sorts. It is the pages you turn to reveal the kind of spaces that are crafted out of the conditions that operate related to currency and the process of working. The book is about exchange. The book is the architectural dimension. Making the book, constructing the pages and the cover that would become the vehicle of the thesis. The assemblage of the book would be a medieval method of making. Each page meticulously considers the layering of transparency and opacity, as metaphors of legality and secrecy.

Strategies in writing are employed in the book as architectural design strategies. The ellipse and the pause, the indent and the void. The narrative can be as explicit and articulate as a clear image. It can obscure, cover, reveal, invite and speculate just as the pages do. There is deposition, excision and relief in the book. Deposition: applying. Excision: cutting out. Relief: accentuating. These verbs can be acted upon a surface in the same way as a relationship, an exchange within time and distance.

The five phenomena in Caracas are the hyperlinks of the book. Each phenomena is expressed in a narrative and displayed as supplementary reading 
on the topic. The reader's curiosity pulls them from the book to the five phenomena essays, inverting the relationship of hyperlinks.

The book sits on a desk that has also been thoroughly crafted and assembled. The wood desk not only support the book in the physical realm, but it is the bridge between the reader and the book. The desk is phenomenologically heuristic. The wood has a smell, a texture, the paper mediums sound when the pages are turned. The desk, a metaphor for the immediate architectural program of money, the bank, encourages the person to think much more conceptually about the bank as an archive, as a repository, as a storage place, as a unit, as a memory palace. The transfer of one thing to another within the spaces we exchange. Only to become obsolete. 


\section{Grey Market Post Script}

The Grey Market lives in back rooms behind the gas station, the grocery store and a house in the barrio. These small rooms are where trade takes place in a currency that is agreed upon at the point of exchange.

The teller on the receiving side of the desk greats the client with a cup a tea and a promise. The farmer passes the chicken through the interface attached to the desk as part of a barter system with the electrician. The travelers educate themselves on the tokens that are considered valuable on that day with the text etched on the desk in the style of oil spills.

The Grey Market lives within the walls of the back room, the banker desk, the interface, the etching on the desk, but most importantly; the Grey Market lives within the relationships of two people exchanging. 


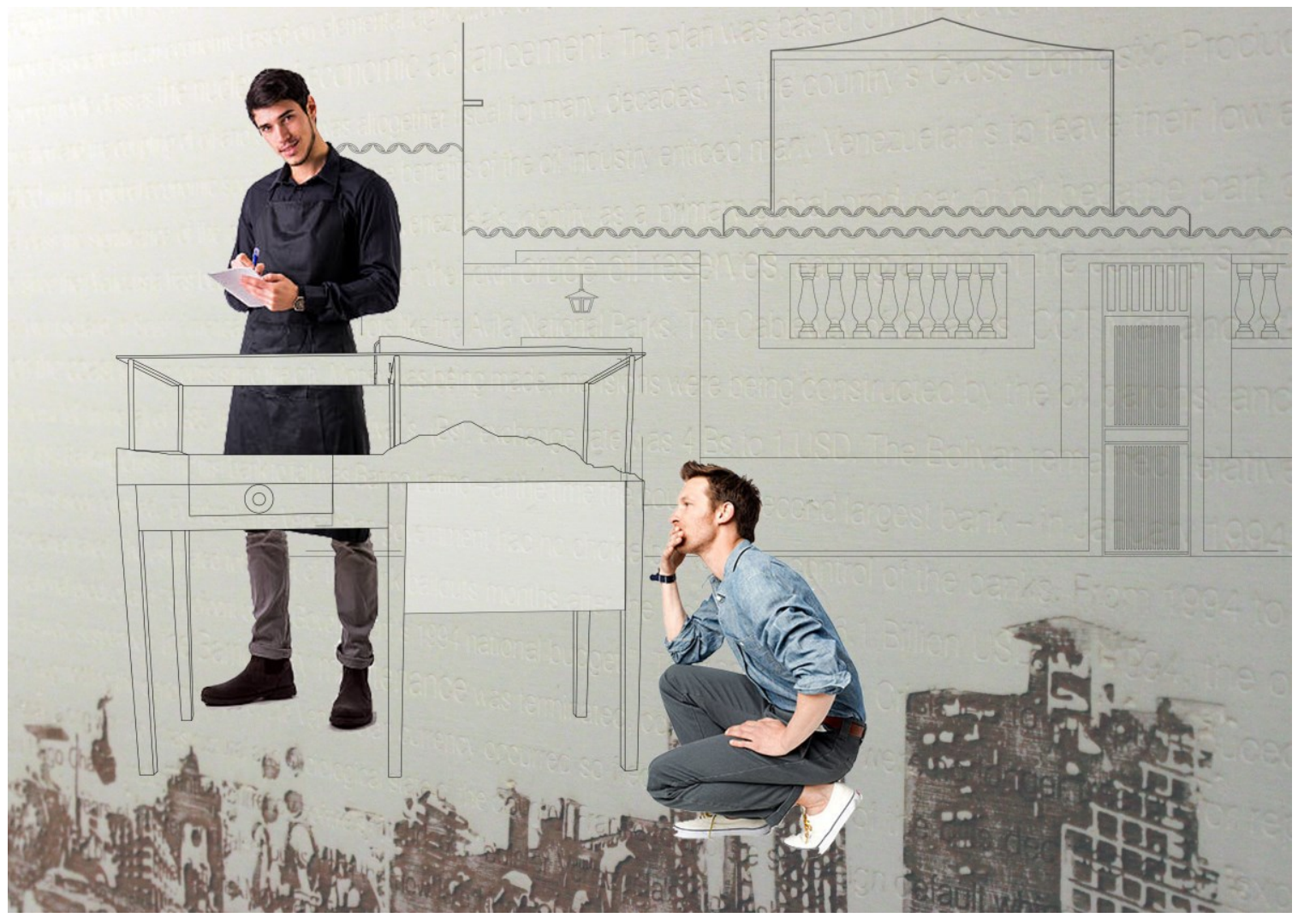

Figure 4-1: Barrio Grey Market 


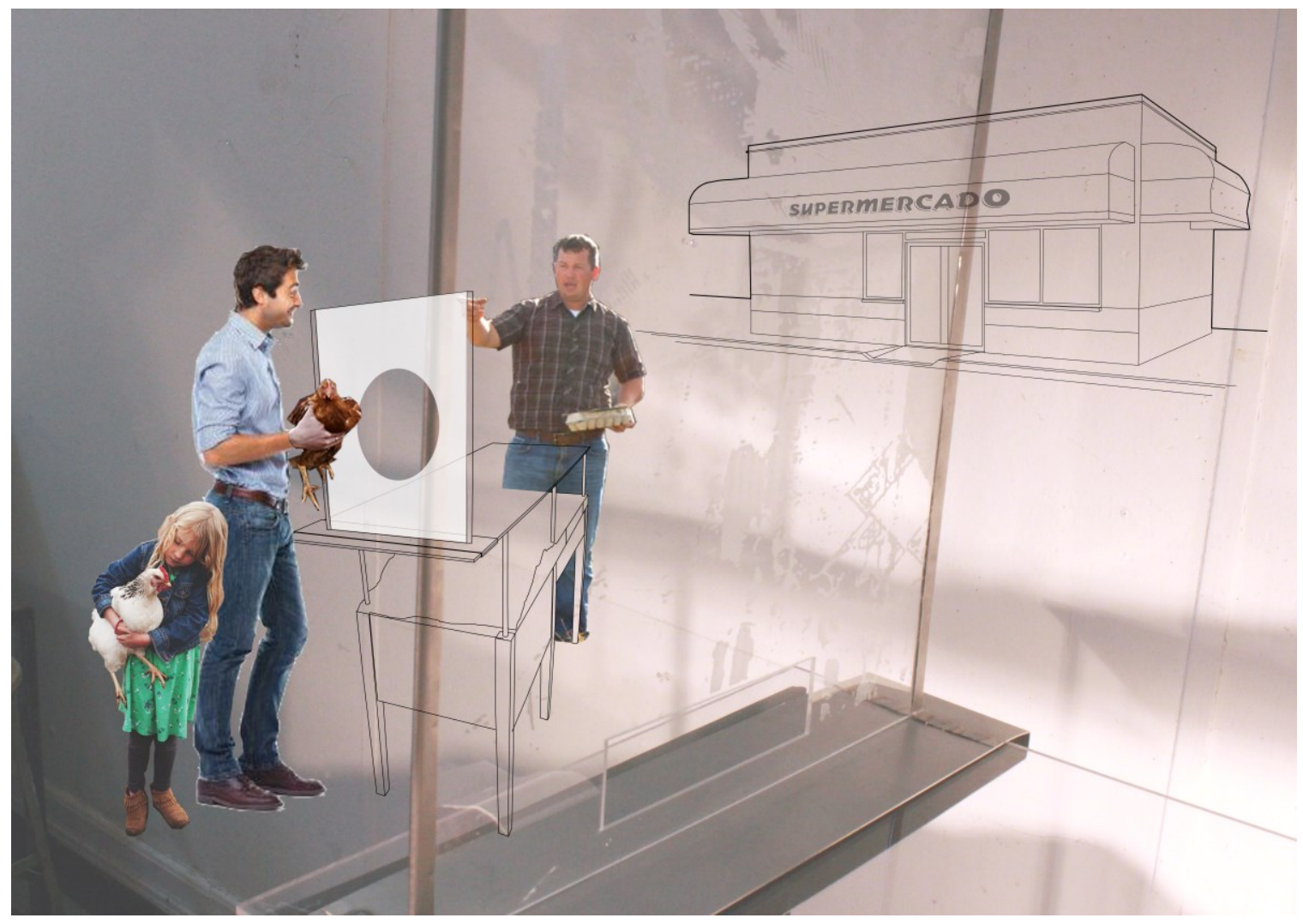

Figure 4-2: Grocery Store Grey Market 


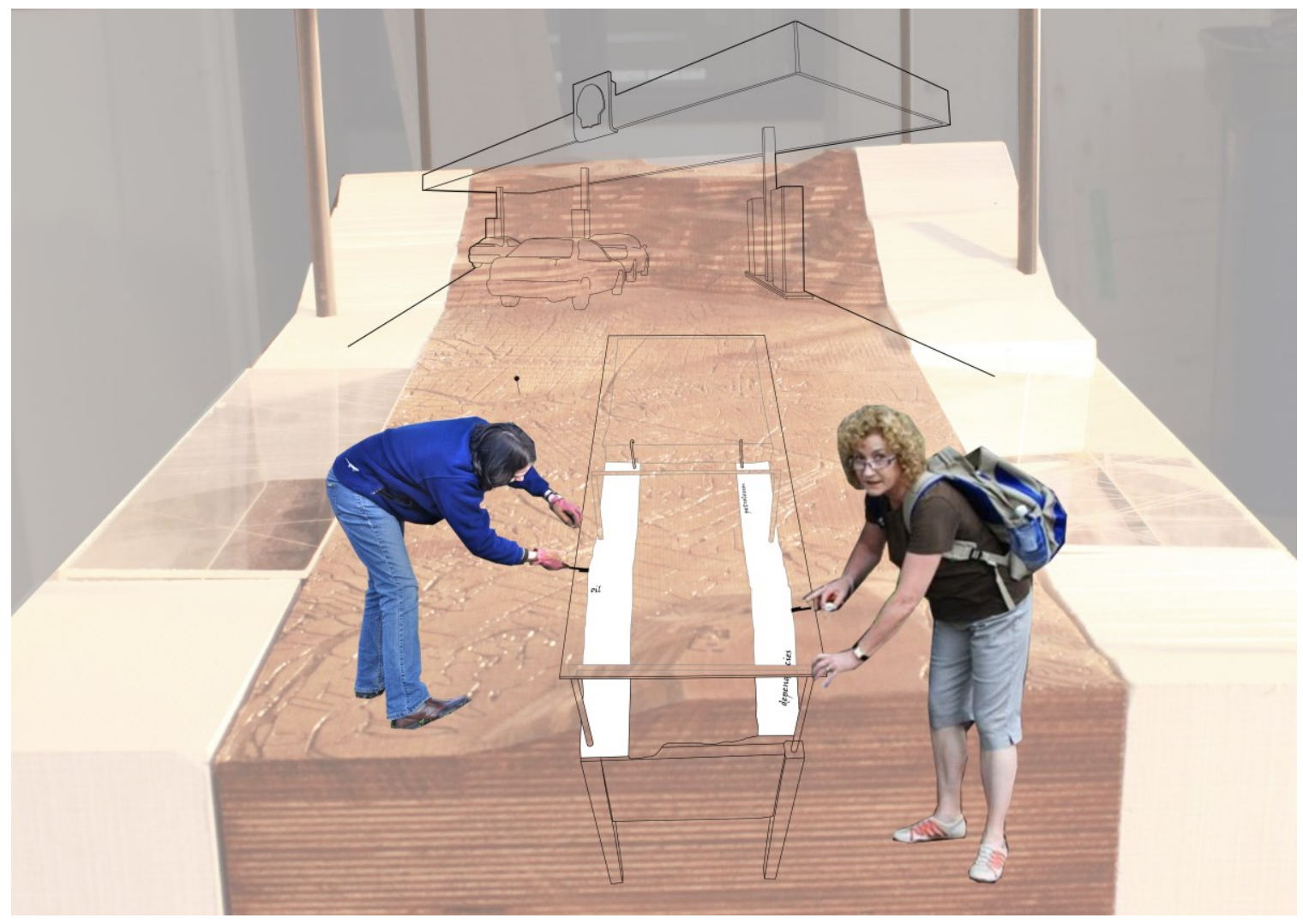

Figure 4-3: Gas Station Grey Market 


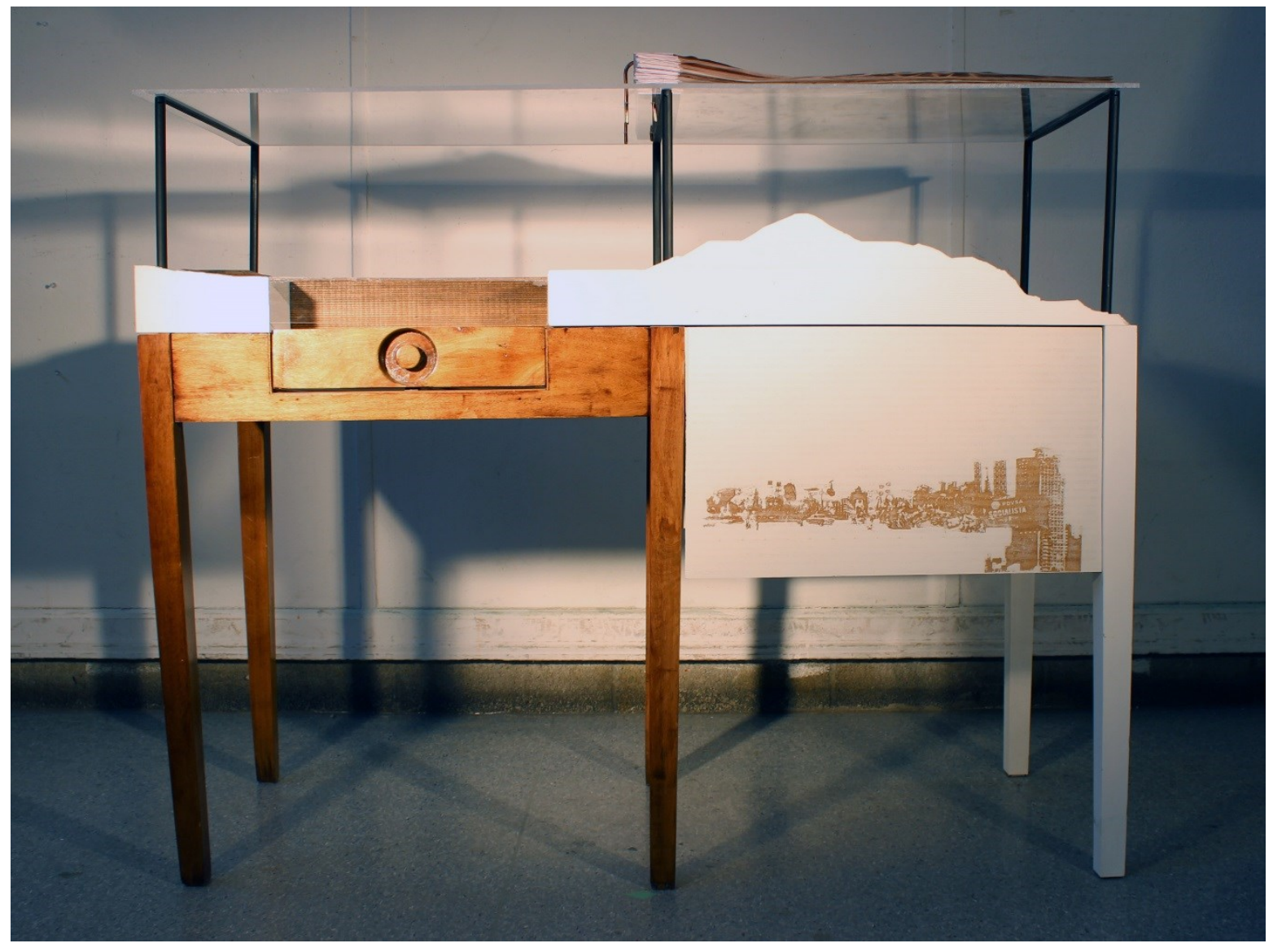

Figure 4-4: Elevation View of Desk 


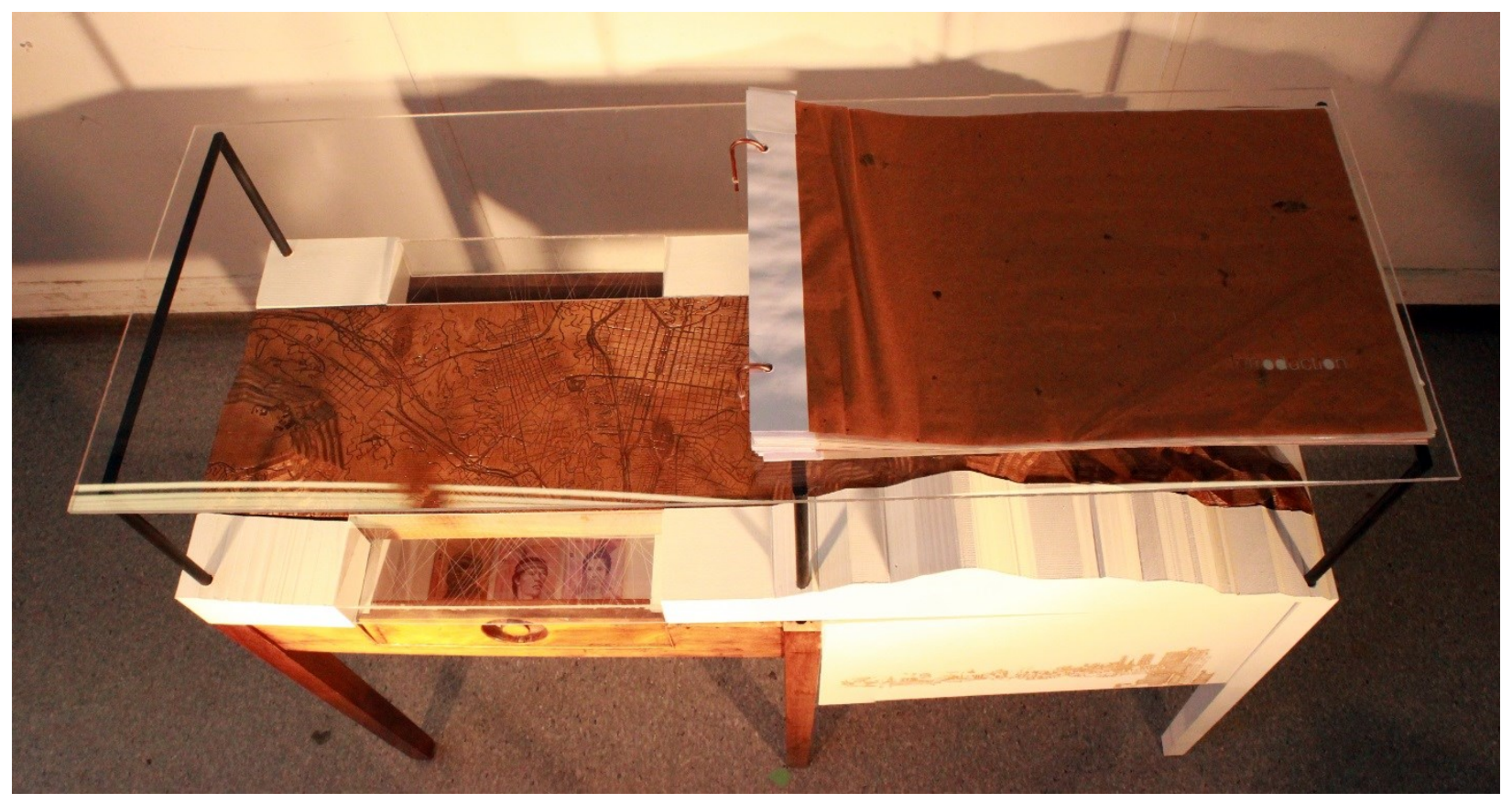

Figure 4-5: Perspective View of Top of Desk 


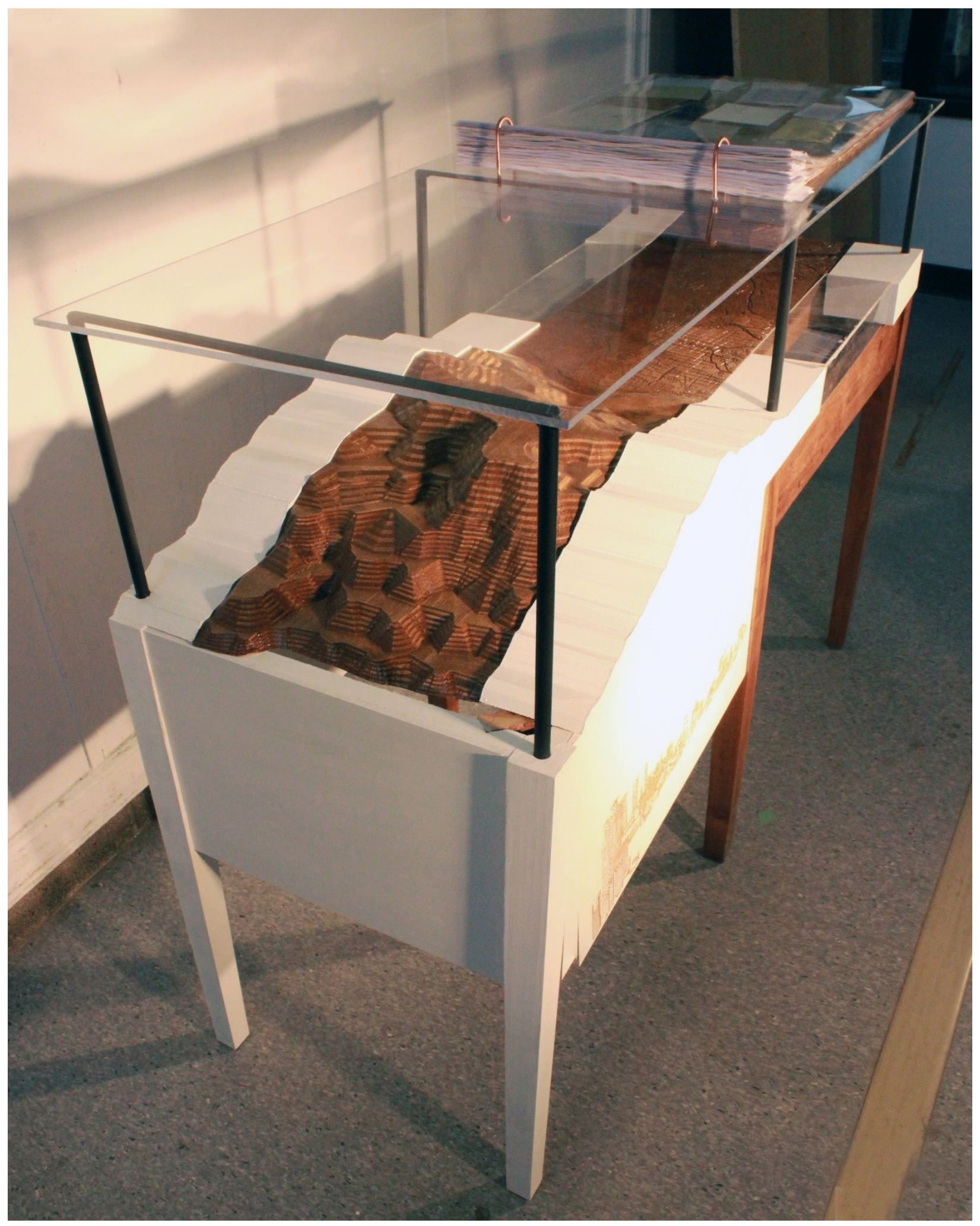

Figure 4-6: Perspective View of Side of Desk 


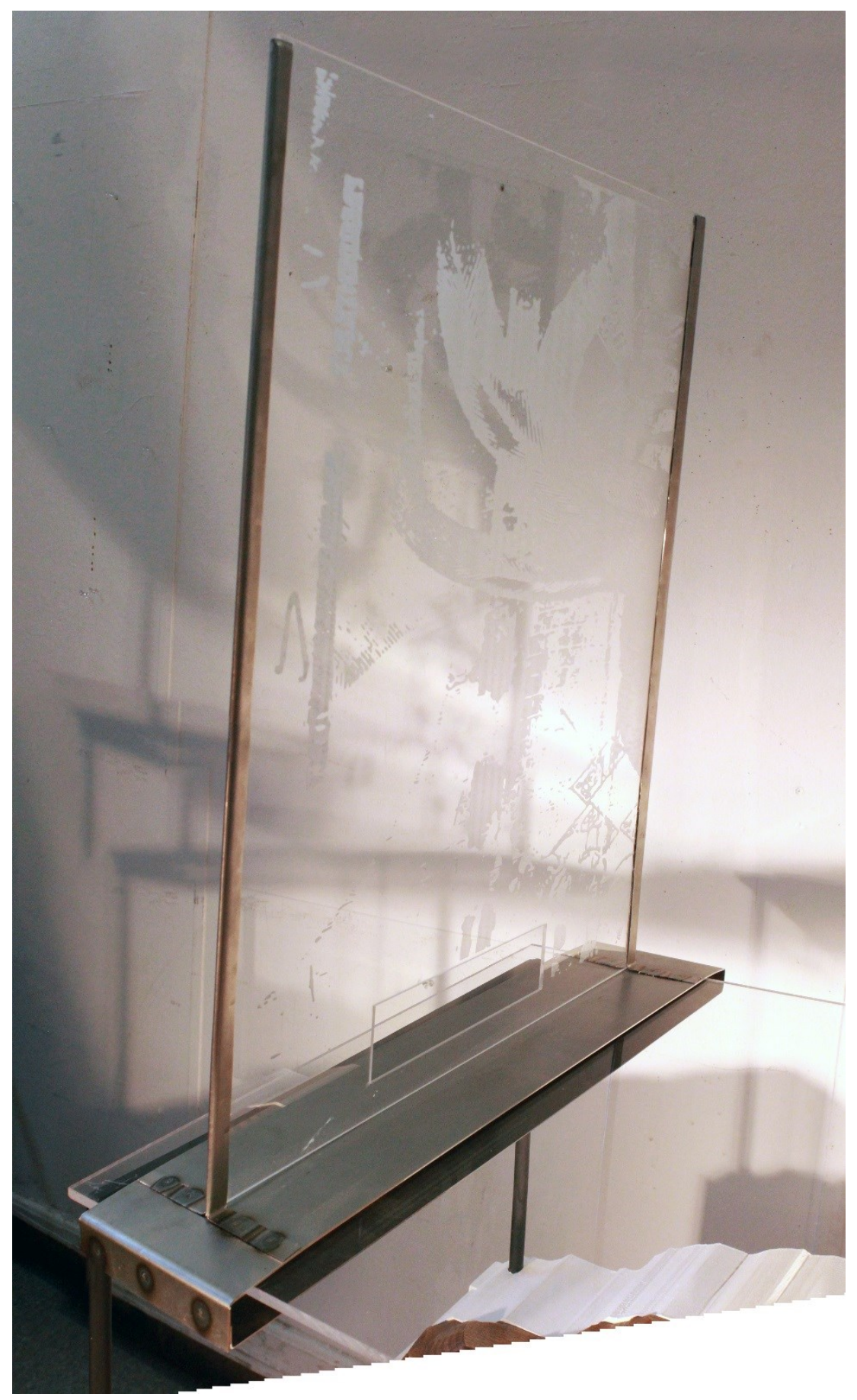

Figure 4-7: Interface 
The image etched onto the plexi surface is the Security Thread on the obverse of the $10 \mathrm{Bs}$. A slot is located at the base of the interface as the window for paper money exchange.

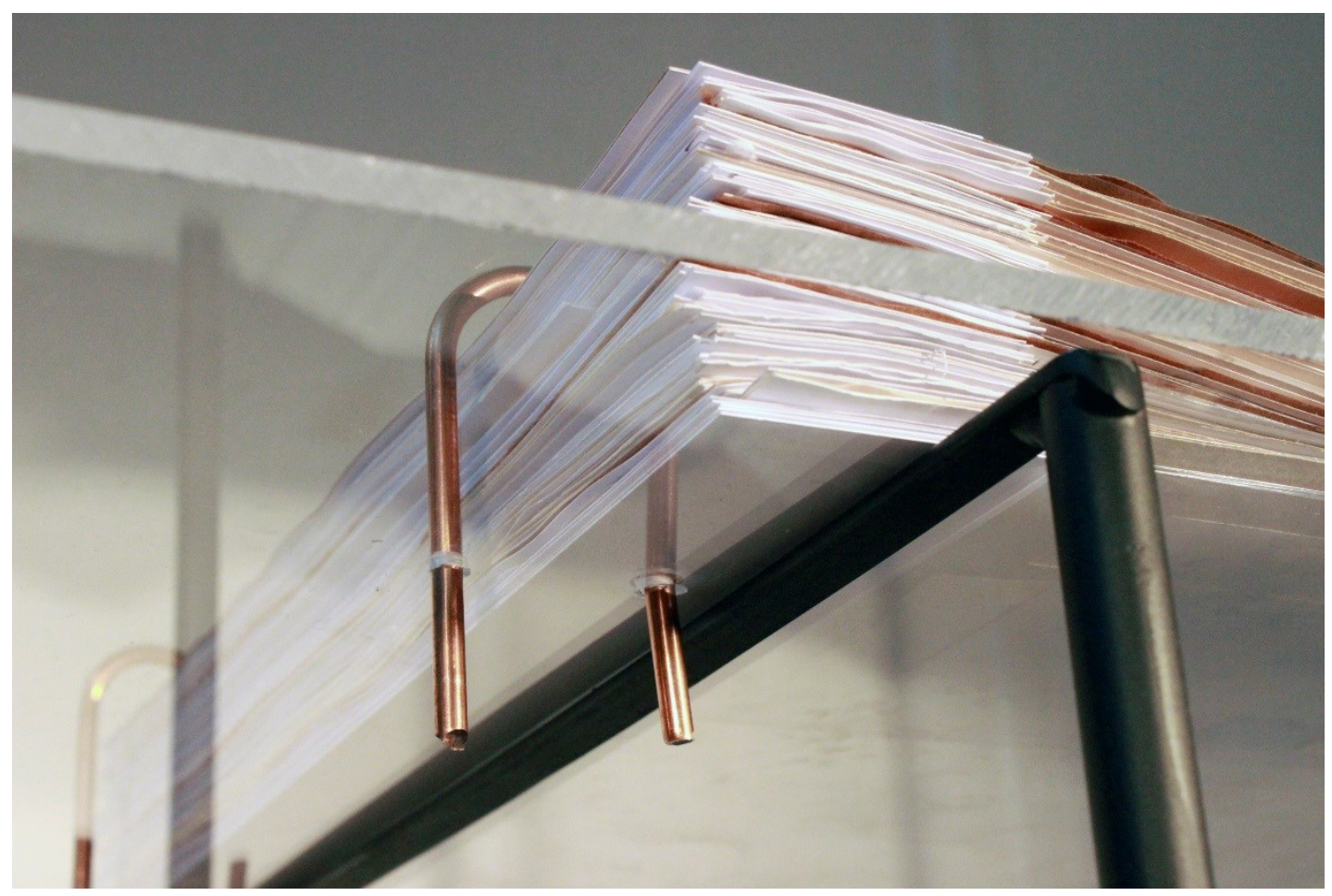

Figure 4-8: Book Binding 


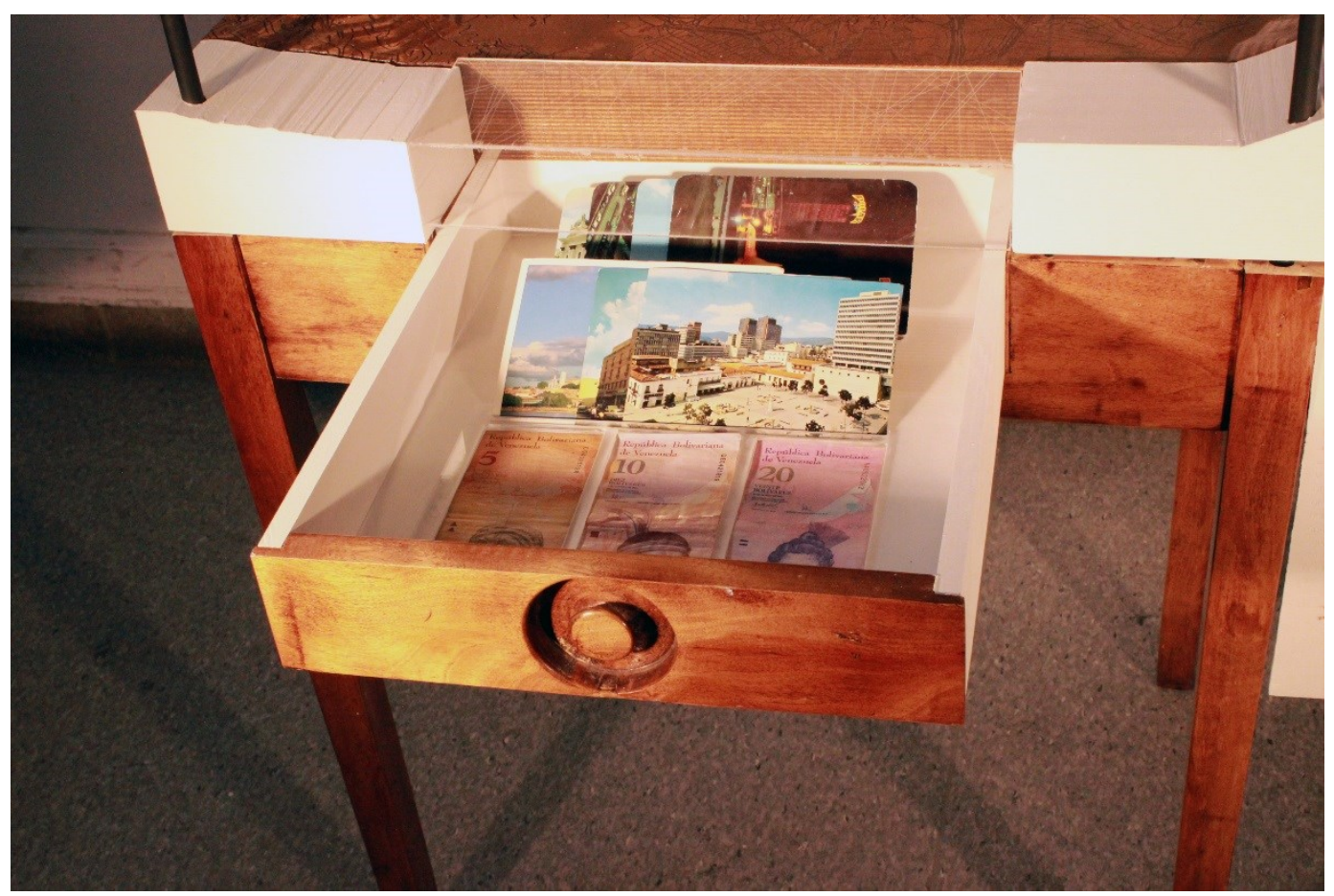

Figure 4-9: Inside of Drawer

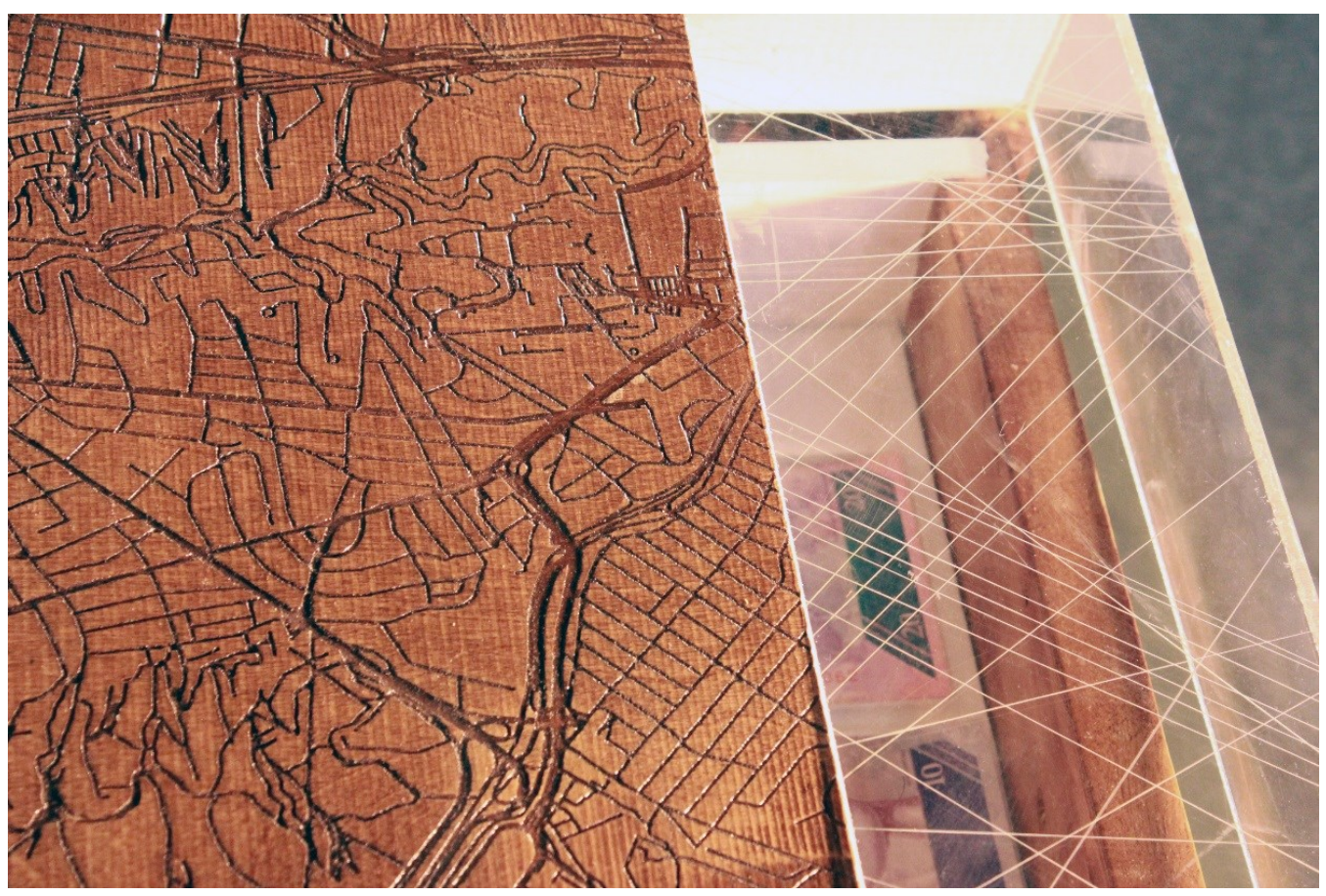

Figure 4-10: Focus of Caracas Plan Extrusion 


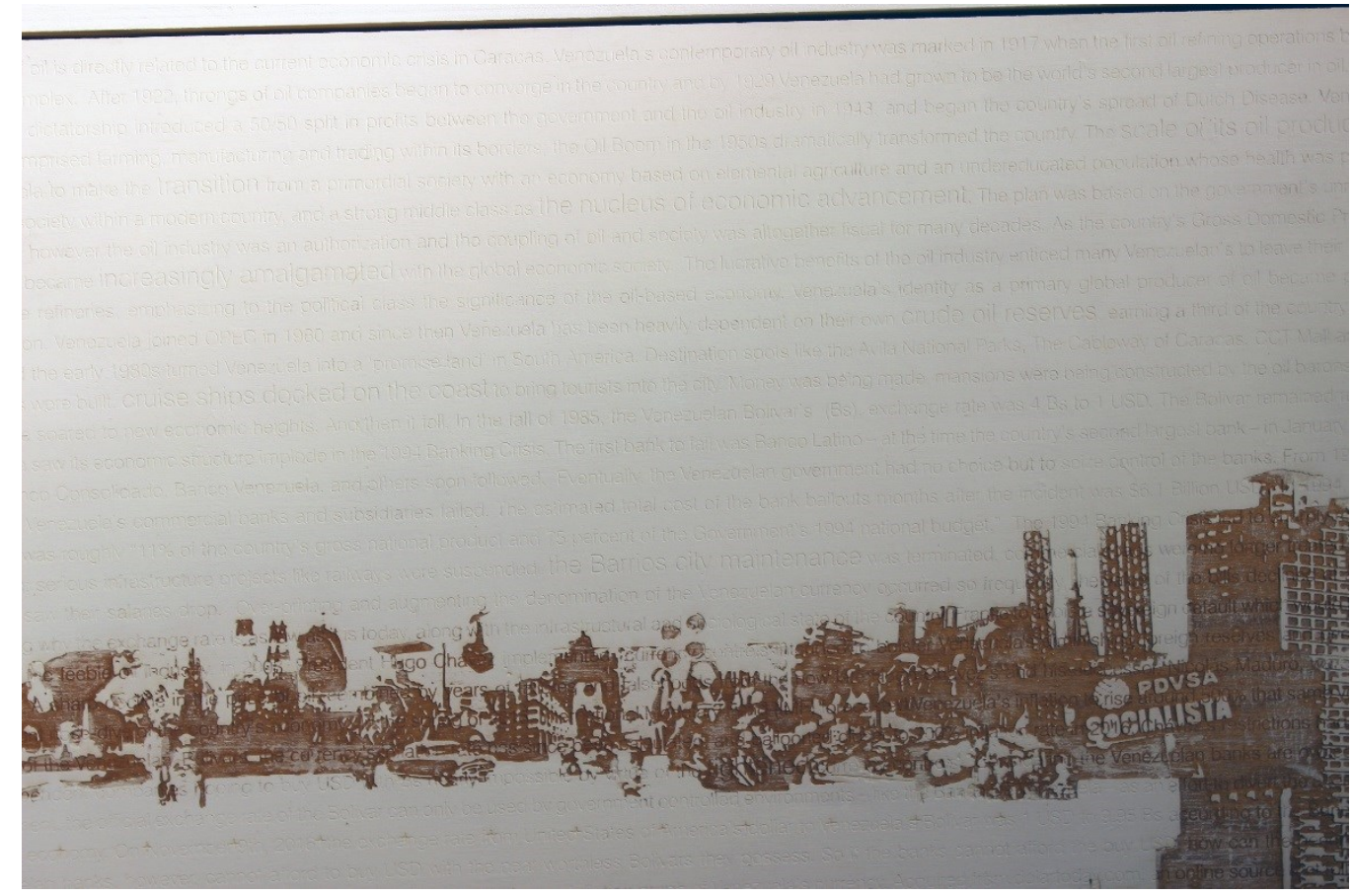

Figure 4-11: Focus of Text Etch on Skirt of Desk

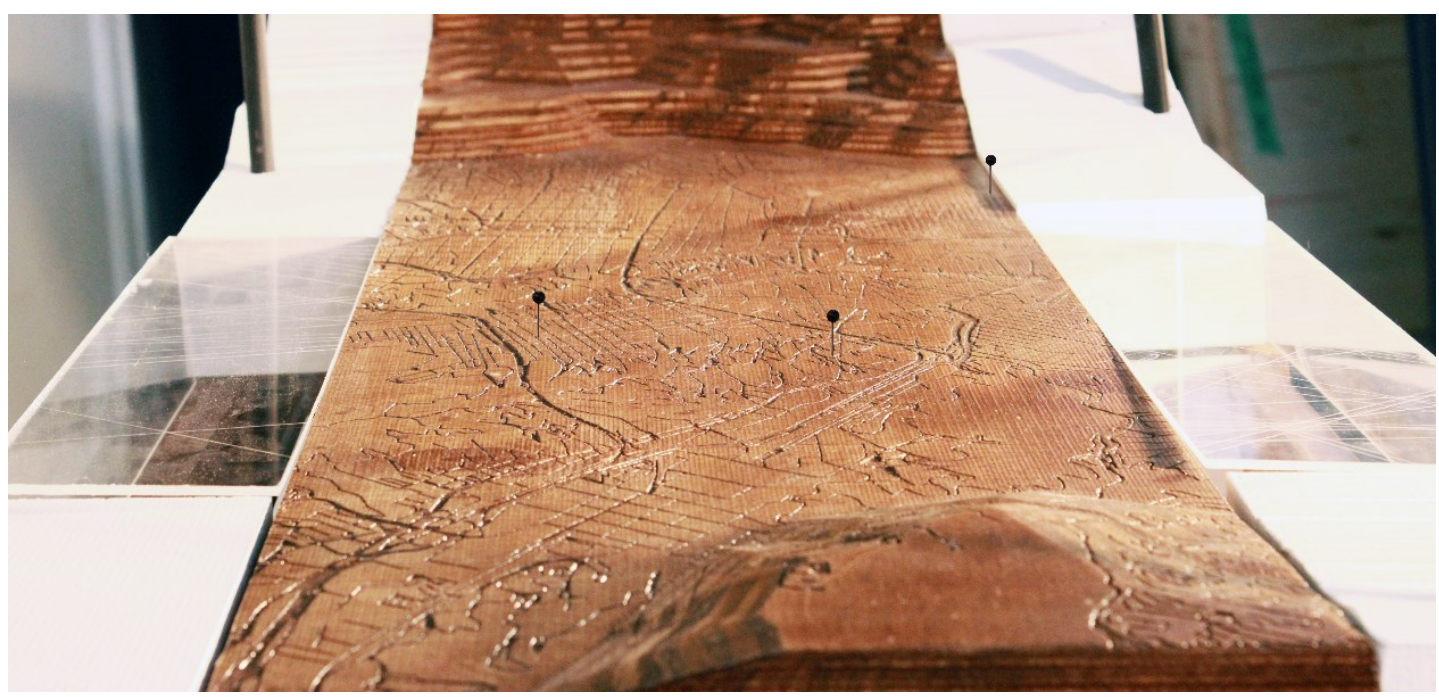

Figure 4-12: Focus on Locating Pins 
Three black pins indicate where the specific gas station, barrio and grocery store are located, and thereby their Grey Markets.

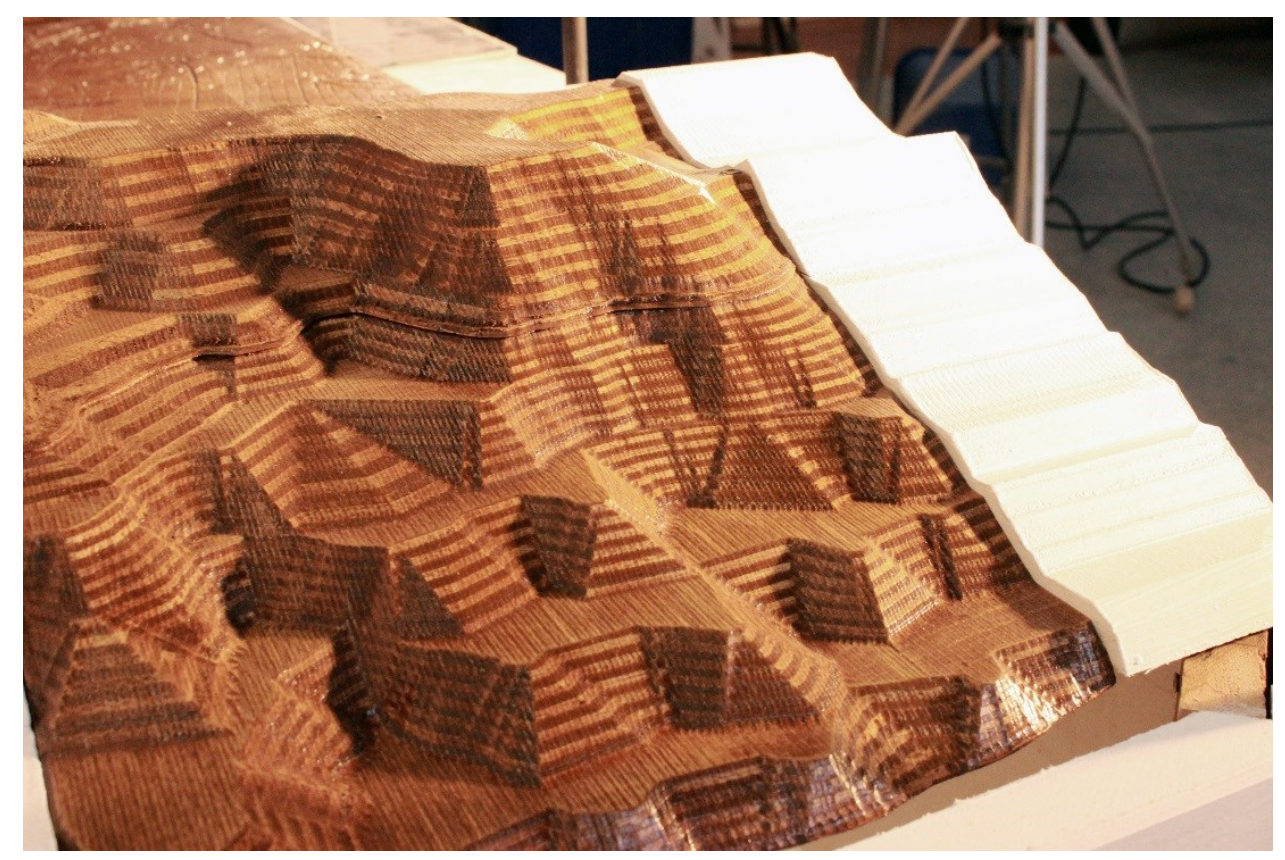

Figure 4-13: Focus of Desk Topography

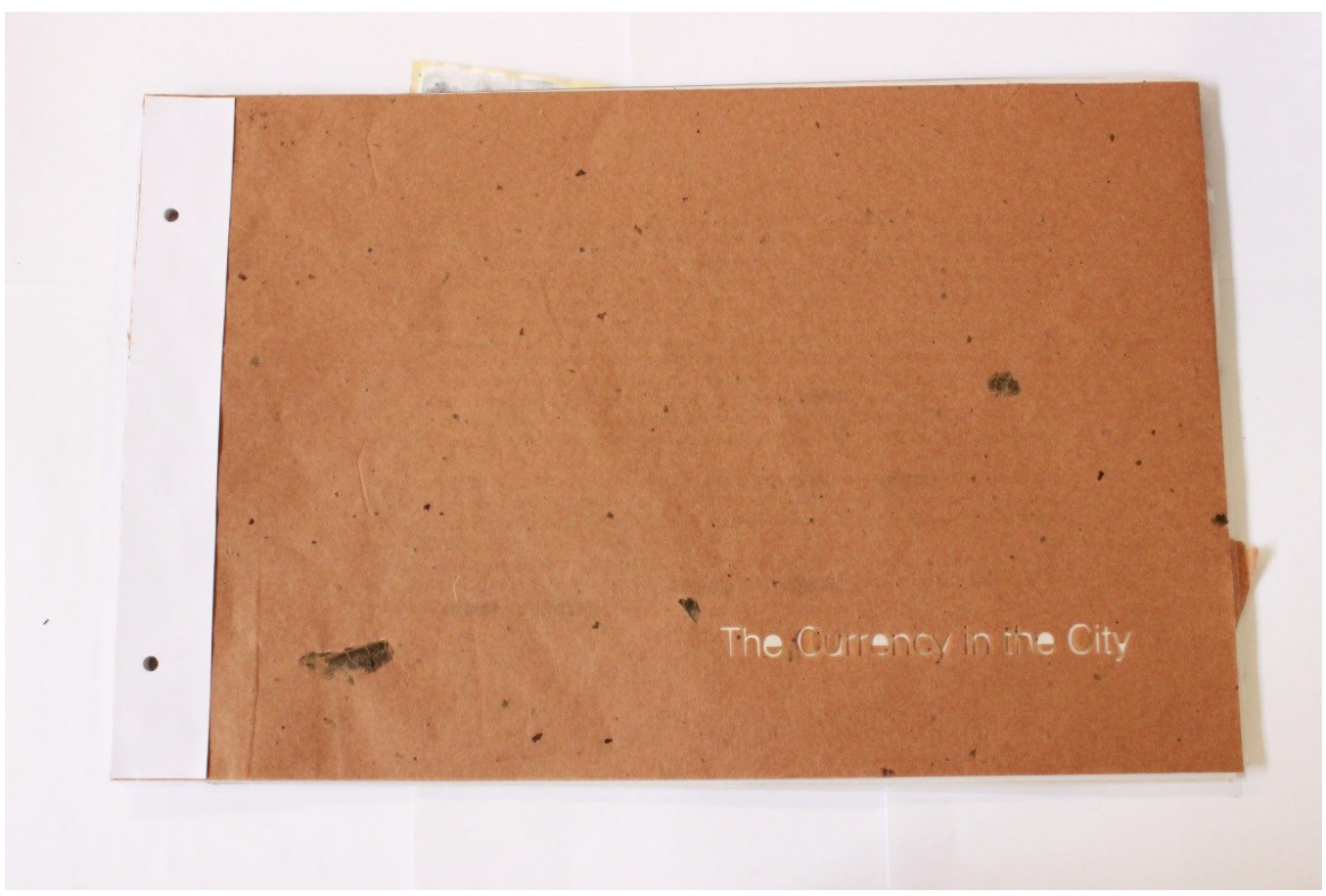

Figure 4-14: Chapter Cover Page of Book [Laser Cut on Kraft Paper] 


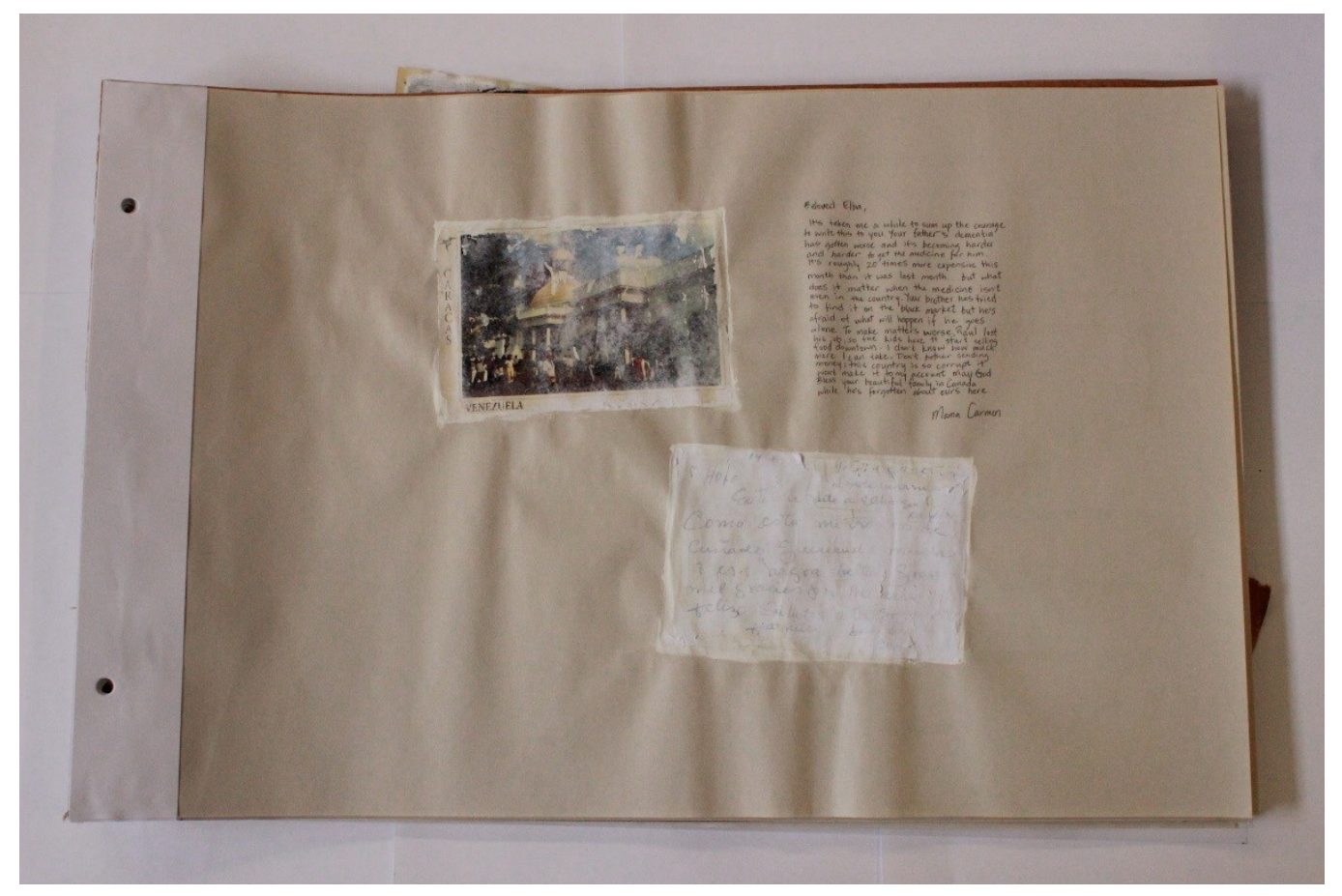

Figure 4-15: Postcard Page of Book [Gesso on Newsprint]

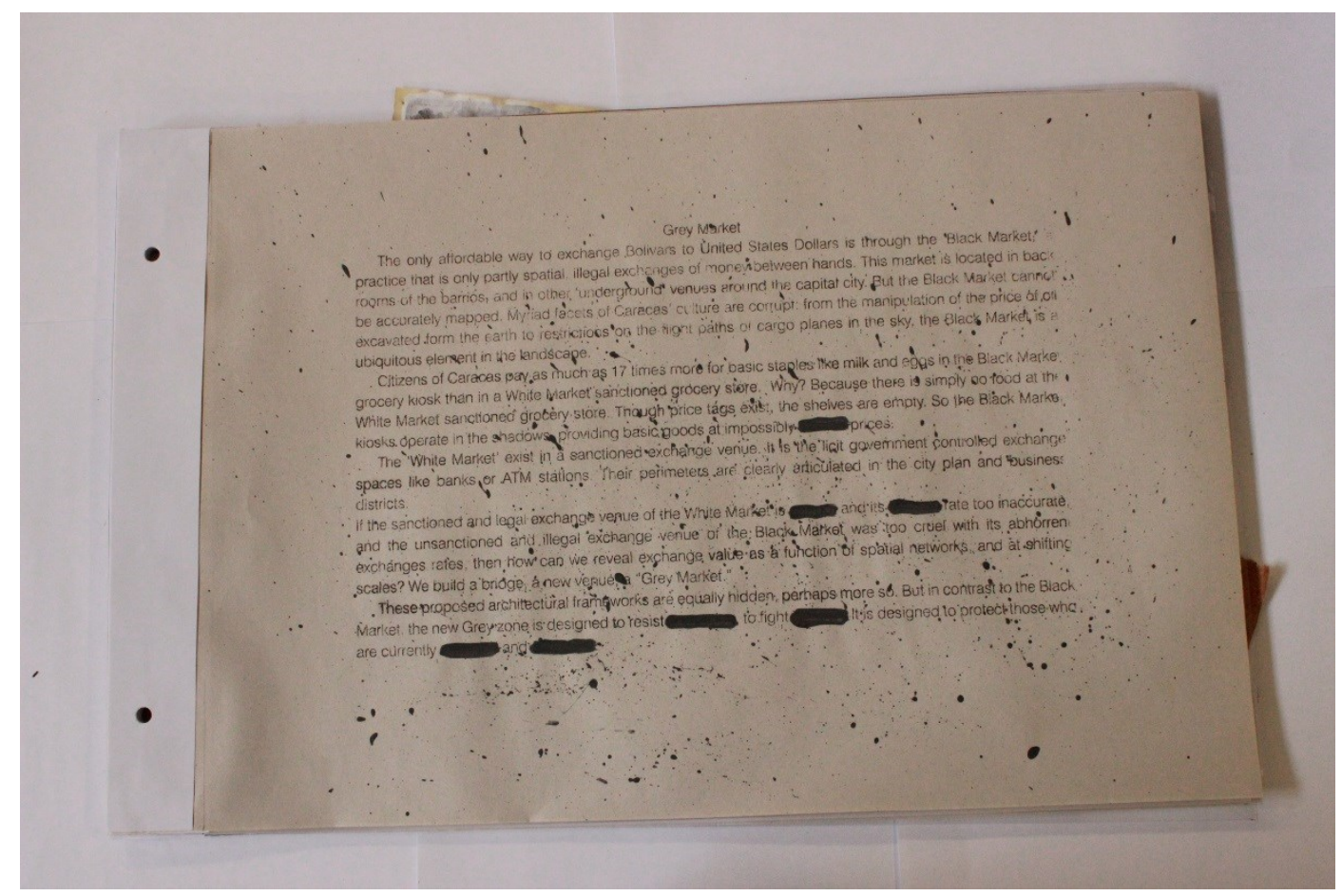

Figure 4-16: Grey Market Page of Book [Xylene on Newsprint] 


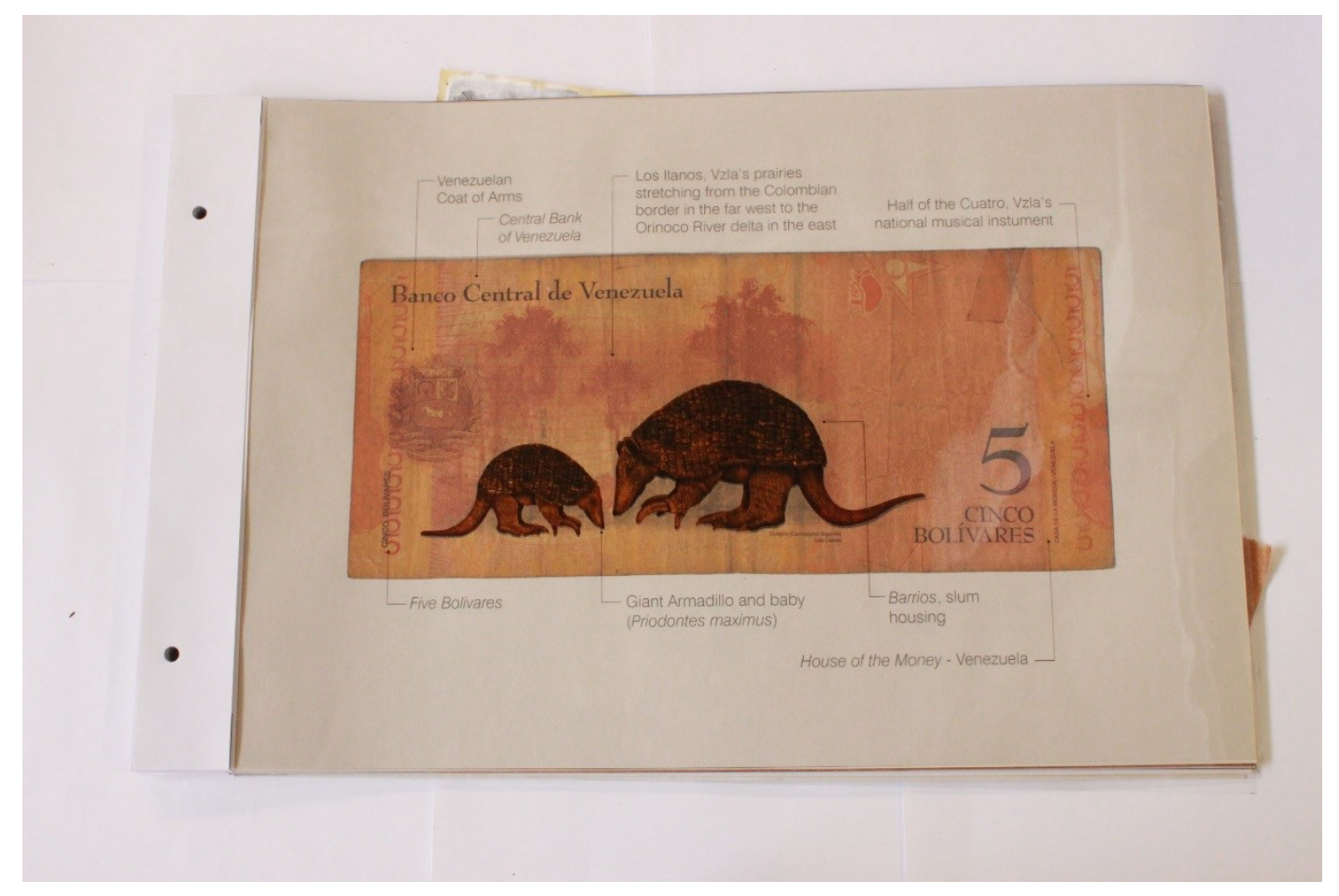

Figure 4-17: 5 Bolivars Modified Page of Book [Acetate Print]

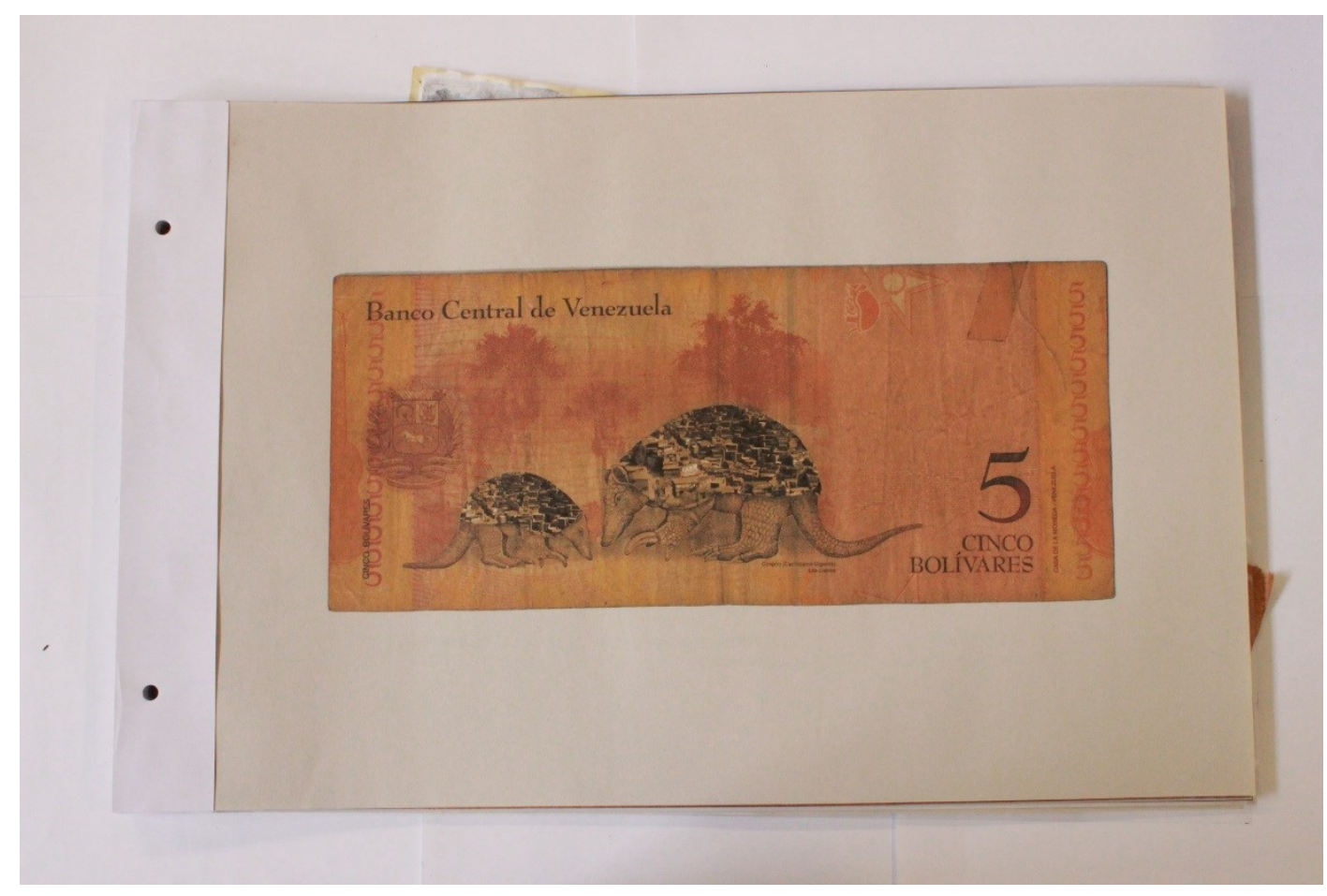

Figure 4-18: 5 Bolivars Modified Page of Book [Newsprint Print] 


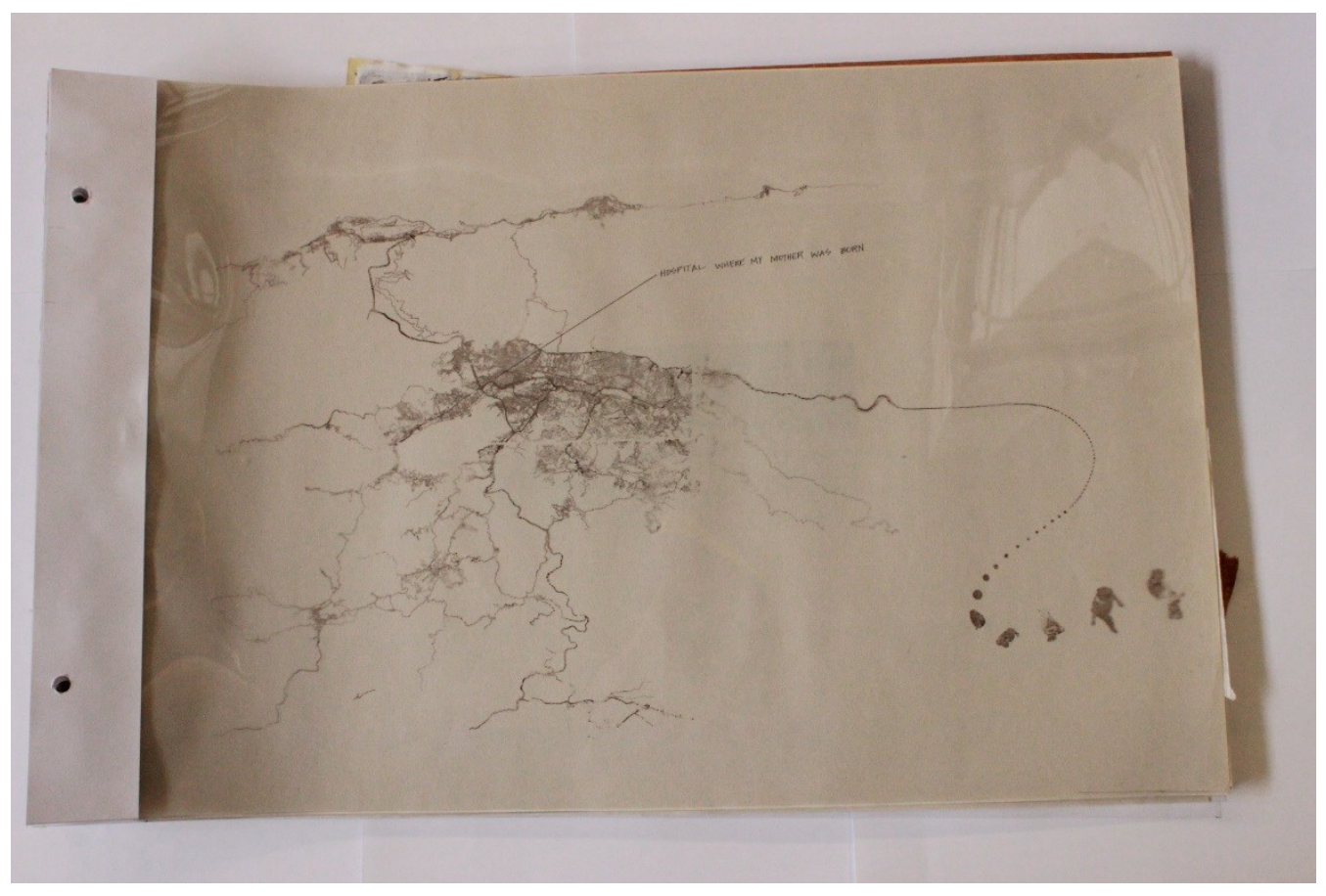

Figure 4-19: Plan of Caracas Page of Book [Acetate on Newsprint]

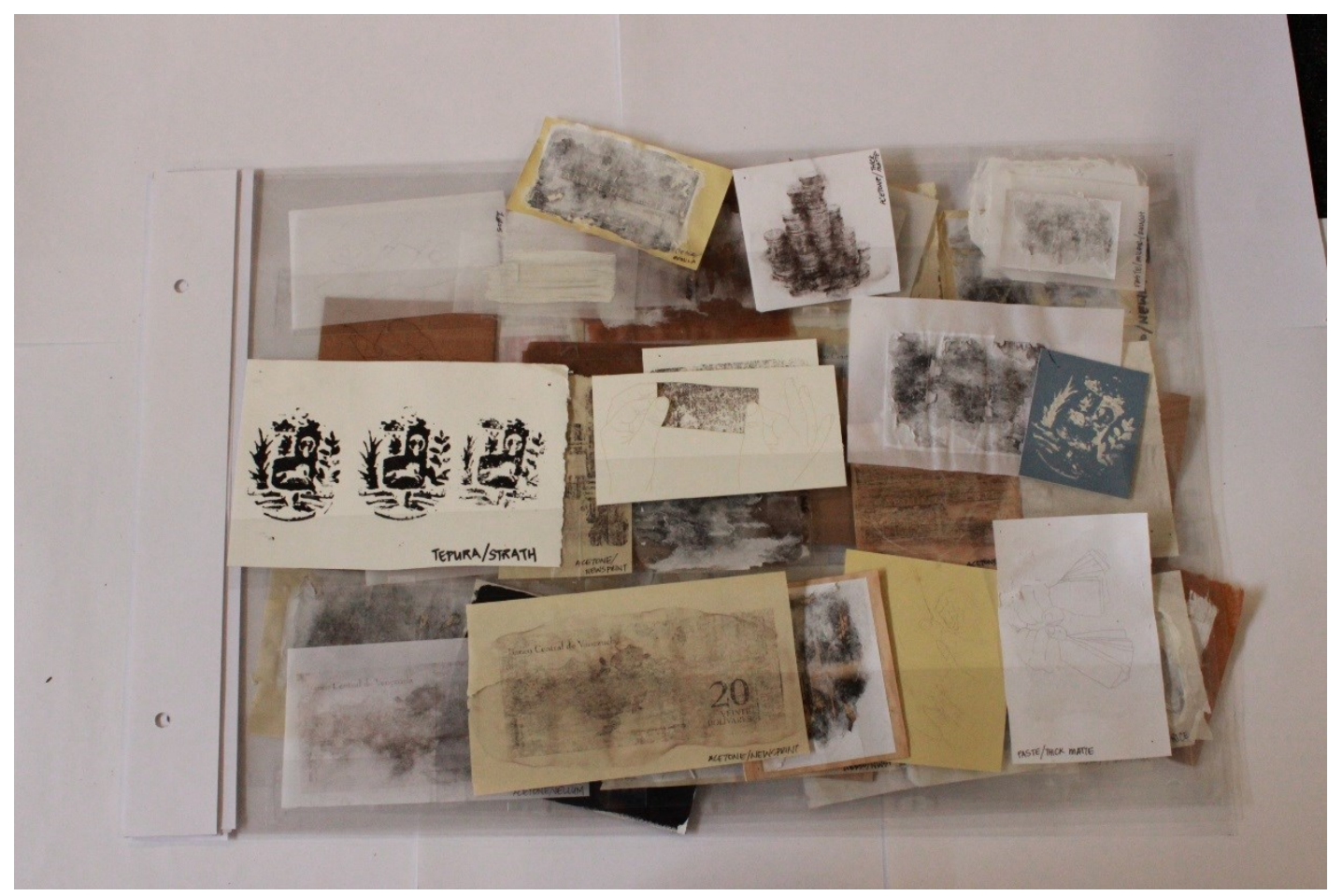

Figure 4-20: Collection of Material Studies 
The last three pages of the Book are the dozens of material studies and experiments conducted to select the pages and the method in which the book would be comprised. 


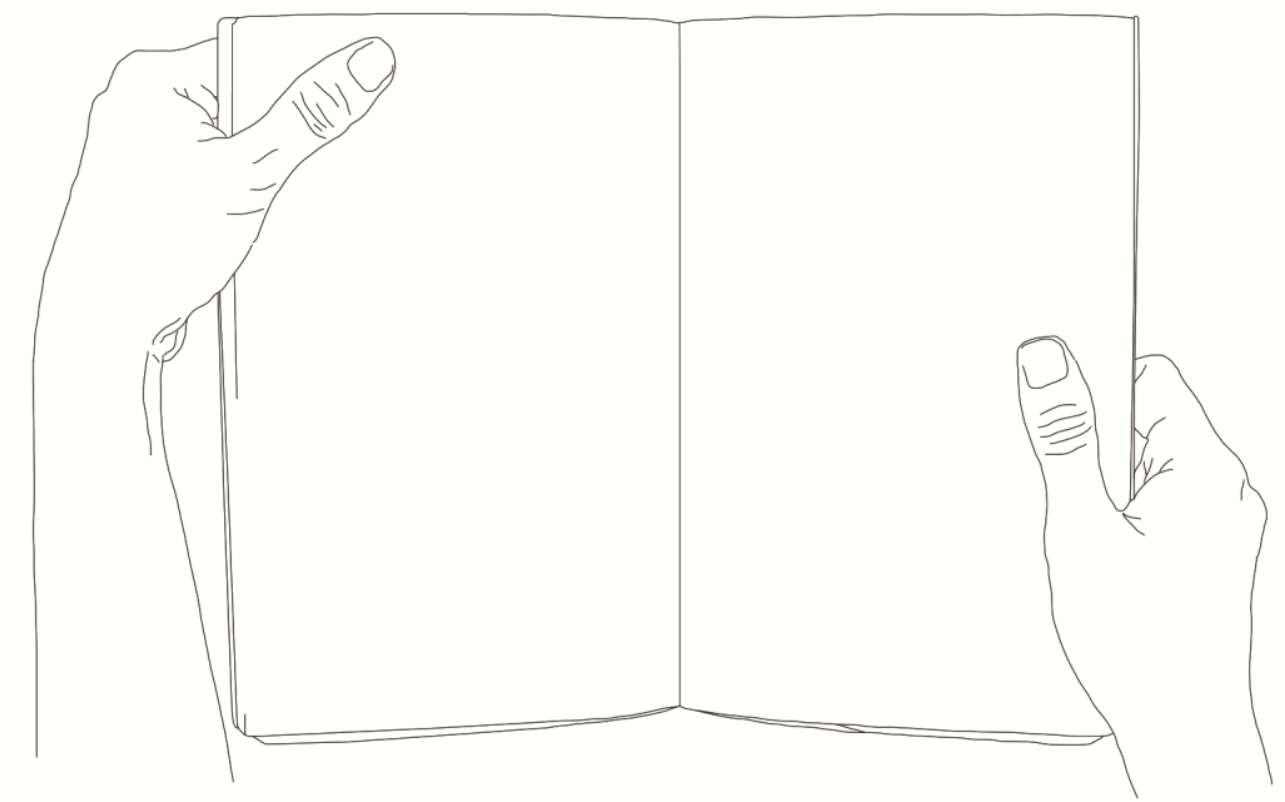

Chapter 5: Five Essays on Spatio-Economic Phenomena 


\section{Inflation}

Inflation, "the continuing rise in the general price level usually attributed to an increase in the volume of money and credit relative to available goods and services." 34

This report encompasses an economic study of the Bolivarian Republic of Venezuela in order to identify contemporary effects of the country's hyperinflation. The first officially recognized Venezuelan bank note was printed in 1940 at the Banco Central de Venezuela (BCV), the largest banking agency in Venezuela of the era. Relative to comparable nations, Venezuela's government authority was lagging in the production of officially issued bank notes.

An in-depth analysis of the components of the 1940 bank note highlights the incorporation of many traditional features common to bank notes and currency from first world countries: watermarks, fine-point line drawings, originally drafted type and historical figures. These features functioned as security measure to assist counterfeiting practices.

It is apparent the government of Venezuela is keenly aware of increasing hyperinflation spreading in the country, but "refuses to publish consumer-price data on a regular basis," ${ }^{35}$ making accurate valuations of Venezuela's inflation rate

\footnotetext{
34 "Inflation." Merriam-Webster. Merriam-Webster, n.d. Web. 21 Mar. 2017.

35 Zerpa, Fabiola, and Andrew Rosati. "Venezuelans Give Up on Counting Piles of Cash and Start Weighing Them." Bloomberg.com. Bloomberg, 31 Oct. 2016. Web. 31 Mar. 2017.
} 
an excuse for speculation. Economists, as a result, were forced to guess the inflation rate in 2016, which ranged from 200 to 1,500 percent. ${ }^{36}$

The last quarter of 2016 saw inflation rates skyrocket such that ATM machines required hourly restocking ${ }^{37}$, compared to two years prior, when restocking occurred every few days. Paradoxically, this great deal of cash is economically worthless in value. The government, as a result, introduced new higher denomination bank notes of to lessen the exponential growth of money in circulation, but in order to have the new bank notes in circulation, only colour and the required zeros were added. Aside from the changes, the design of the bills remained the same.

\footnotetext{
${ }^{36}$ Zerpa, Fabiola, and Andrew Rosati. "Venezuelans Give Up on Counting Piles of Cash and Start Weighing Them." Bloomberg.com. Bloomberg, 31 Oct. 2016. Web. 31 Mar. 2017.

37 Zerpa, Fabiola, and Andrew Rosati. "Venezuelans Give Up on Counting Piles of Cash and Start Weighing Them." Bloomberg.com. Bloomberg, 31 Oct. 2016. Web. 31 Mar. 2017.
} 


\section{Deprivation}

Deprivation, "to take something away from and especially something that is usually considered essential for mental or physical well-being." ${ }^{38}$

An elder woman living outside of the city wakes up at midnight and readies herself to make the trip. She doesn't prepare breakfast for herself because she has no food. She grabs her purse, steps out of her apartment, down the flight of stairs and through the main entrance of her building. Walking through the blackness alone, she is heckled by the men who stand on the street corners drinking all night because they have nothing better to do. She ignores them and keeps walking, clutching her purse tighter. Arriving at the bus stop, she receives a nod of acknowledgement from the other women standing for the bus. Though everyone knows each other, no one is in a mood to speak.

The bus arrives and the women embark. It is typically an hour to the city, so the elder woman chooses a seat by the window and stares out at the moon. She reflects. The broken glass, the smell of heated trash and the loud music playing lets the woman know the bus driver has reached the city limits. She clutches her purse tighter. Some women on the bus look out the windows at the city, others don't bother. They know the view hasn't changed for months.

The elder woman arrives at her bus stop. She thanks the driver and steps off. Few lights illuminate the short walk from her stop to the grocery store. She

\footnotetext{
38 "Deprive." Merriam-Webster. Merriam-Webster, n.d. Web. 21 Mar. 2017.
} 
keeps herself alert in the night by scanning the dark with each step. She knows these people here are deprived too. For food, for safety, for security. She knows deprivation leads to desperation. She knows it's the desperate people who attack first. She clutches her purse tighter and walks on.

She reaches the grocery store. To no surprise, she is not the first in line. She does a quick head count, and the elder woman concludes that she is standing behind 23 people. It is now 1:35 in the morning. She watches a young child sleep over his father's shoulders. She is wondering how long it has been since the child has had a substantial meal. The line behind her grows with more tired families. Parents who haven't slept in days with their children who haven't laughed in days. The elder woman knows the only way to pass the time in line is to people watch. But it's too depressing. She knows everyone needs what's inside the grocery store, but far less than half will walk away with their basic needs. She knows there is no guarantee that any of them will be able to purchase even toilet paper or milk. She doesn't allow herself to feel sad, "This is how our country is run now," she thinks to herself.

The elder woman stands in line and clutches her purse, waiting for the grocery store to open. ${ }^{39}$

\footnotetext{
39 Post Script: Based on personal narratives, as well as an article written by Hannah Dreier of AP's The Big Story on July $12^{\text {th }}, 2016$. In this article entitled "Life on the Line in Venezuela as Economic Crisis Worsens," Dreier notes an 80 year old woman crushed to death by a queue of people suddenly turned into a violent mob.
} 


\section{Corruption}

Corruption, "dishonest or illegal behaviour especially by powerful people (such as government officials or police officers)." 40

Hire eight to twelve people. Delegate each individual's roles on the project: the printer operator, the manager of supplies, the bill cutter, the lookouts, the packager, the receiver, the transporter, the threader and above all, the designer. The designer's role will carry the highest level of detail, therefore ensure your selection is a perfectionist who is meticulous in their craft.

Buy the equipment clandestinely. The printer must be of high quality and able to mass produce at efficient rates. Sophisticated scanning and design softwares are imperative for production. Offset begins by digitizing the currency, therefore the negative is vital. The negative, however, cannot capture the intrinsic subtleties of the bank note like the water marks, regardless of the scale of the scan. The designer is tasked to touch up the detail by hand.

Acquire the raw materials from trusted sources. Requirements include various types of ink, glue, flour, thread, water and cotton and linen blend paper, to name a few. Luckily, the ingredients are cheap. Glue and flour should never

\footnotetext{
40 "Corrupt." Merriam-Webster. Merriam-Webster, n.d. Web. 21 Mar. 2017.
} 
cost you more than $\$ 1$ USD. The paper must be bought in bulk but merely costs \$10USD - \$15USD a stack.

Set up the factory away from the city. The printers grow distinctively loud when spitting out mass produced sheets of currency. The loud nature of the functioning factory makes working at night undisputable. The factory must be up in the hills, in prefabricated structures, away from the people.

Begin production. Exactness and efficiency are paramount in mass production of counterfeit currency. At a summit, factories can fill an order for $\$ 5$ million USD in one week, all in \$100 USD bank notes.

Pay attention to every detail. Assign the threader to thread the security strips into each bill by hand. In order to achieve the illusion of authenticity, the threader much soak the bill in water, then insert the needle and thread.

Test the bank note's tactility. In order to improve the raised lettering, mix exact counts of flour, glue and water to achieve even consistency. Accurately apply the glue mixture onto specific areas of the bank note. When left dry, the bill will bear a rippled effect on the specific areas of the bank note, similar to the texture of an authentic bank note.

Never stop innovating. Venezuelan currency is worth less than the money value printed on the paper. Using Venezuelan bank notes as raw material cuts down costs on producing counterfeit bank notes. Simply bleach off the portraits and renderings on the original bank note and print the design elements of the bank note to wish. Beware of the text within security elements. For example, the 
Bolivar security thread is impregnated with the words 'diez' meaning "ten." When reprinting, ensure each security feature remains consistent with the altered currency design. Guaicaipuro's face can become Benjamin Franklin's. The paper will already be authentic to the touch, however when holding the counterfeit bank note under a microscope, outlines of the defaced Venezuelan currency can be faintly detected.

Sell. ${ }^{41}$

${ }^{41}$ Post Script: Based on an interview conducted by The Guardian on March 31st, 2016 entitled, "'Counterfeiting is an art': Peruvian gang of master fabricators churns out $\$ 100$ bills" In the article, author Jonathan Franklin interviews an incarcerated Peruvian king pin of counterfeiting currency on his practice, with particular emphasis on Venezuelan' currency. 


\section{Defection}

Defection, "an imperfection or lack that causes inadequacy or failure; a shortcoming or deficiency / abandonment of duty, allegiance"42

I was seven years old when our parents brought Luis home from the hospital. l've been told the oldest sibling commonly feels jealousy when there's a new baby in the family, but that was not the case for us. From the moment we met, I knew it was my job to protect and support my little brother. I'd been doing a good job watching over him and making sure we both helped out our parents at home and around the house when we were growing up. But things became different in the winter of 2016.

It was nearing Christmas and the city was awash with cash. Worthless, ironically heavy, cumbersome cash. Our currency had dropped in value so swiftly in that year, that one month you needed to stuff your jean pockets with wads of paper money to buy milk, the next month you needed to stuff an entire gym bag. Just walking to the market became an ordeal: we ran to avoid getting mugged. I remember Luis asking me why we had to sprint out of the underground when our subway doors opened. It was because we had more cash on us that most people did. Looking back, it made no difference.

Working at our father's convenience store made our lives more subject to danger. I would never let Luis work by himself at the store. When the tills were

\footnotetext{
42 "Defect." Merriam-Webster. Merriam-Webster, n.d. Web. 21 Mar. 2017.
} 
about to overflow with currency, our father made us hide the cash in boxes, under our mattresses and even inside the walls of our house. We are members of the $40 \%$ of the country that doesn't have a bank account. We had boxes stacked as tall as our father, full of $100 \mathrm{Bs}$ - the country's highest denomination at the time. Our neighbour owned a bakery and found that it was faster to in fact weigh the cash on his electronic scale instead of counting it. This was one solution to shortening the queue that was snaking out his door and around the block. He laughed when he told us that he felt like a drug dealer with all the money he had. Luis and I felt the opposite. It would make me sad to think that there was a time when all this cash would've made us rich. Rich enough to leave this country.

I remember the morning when Maduro announced that Venezuela was to receive higher denomination bank notes as an attempt to solve the copious amount of paper currency circulating. "Isn't it still the same problem, just more zeros on a piece of paper?" said Luis. He knew it was a band-aid for a bullet wound. Our mother and father began that night counting all our $100 \mathrm{Bs}$ bank notes we had saved around our house into mountains. We built an extra room to accommodate the piles, then stacked them to the ceiling. The need for architecture hid the fact that money was worthless.

It wasn't until the night of December 12 that Maduro lit the match that started the inferno. Our president announced on broadcasted television that the government was taking all 100 Bs out of circulation in ten days. I remember watching the glow of the television bounce off our parents shocked faces. Luis 
was the first to break the silence, "Wait, what does that mean for all the 100 Bs we stacked in the new room?" It was like Maduro heard him and responded. He said the banks across Caracas will be open tomorrow for the sole purpose of exchanging our $100 \mathrm{Bs}$ for the new higher denomination bank notes. Anxiety overtook sleep that night as we all lay awake in our beds.

The next morning was madness. Our father, Luis and I took the subway to the city with two duffle bags each. Before we left the house, Luis had to sit on each bag so I could force the zippers shut. I was certain the bags would burst at the seams when we rode the subway with what seemed like every citizen in Caracas, all carting every 100 Bs they possessed in bags. I knew we were going to make many trips within the ten day grace period.

The three of us fretfully stood in line at the Banco de Venezuela on Simón Bolivar Avenue. Our father told us not to get out of the queue, and keep our hands on our money. In order to pass the time, I lent Luis my smart phone to play games on while I kept an eye on the queue. The day was hot and where we stood in the line was directly in sunlight. I guessed how long it would take before the shade of the palm trees along the entrance of the bank reached us, but the queue felt like it wasn't moving at all.

Luis would nudge me whenever my phone buzzed with a notification. The lunacy of this exchange operation had reached Facebook and Twitter. Some people were setting their 100 Bs on fire, while others joked of using it as monopoly money. A friend of mine tweeted a photo of his piles of $100 \mathrm{Bs}$ in the bathroom, 
claiming he might as well use them for toilet paper since actual toilet paper is so hard to come by. Later that day Maduro had the nerve to tell us that the reason for all of our food and daily supply shortages was because of the "economic war" being waged against Venezuela's government.

As predicted, this circus went on for days. While waiting in line we read news articles quoting Maduro on his motives for taking the 100 Bs out of circulation. It was a move that would "strike against the mafia." Maduro continued that Venezuelan gangs were hoarding more than 300 billion worth of currency in warehouses abroad. Venezuela was also apparently blocking their boarder with Colombia to prevent these gangs from exchanging their hoarded bills. I suppose Maduro's thought process was that once the deadline for exchange had passed, all the smuggled money would become useless. "Papi, how many 100 Bs do you think are in circulation now?" Luis asked. A stranger in the queue of the bank answered him, "Apparently six billion. And that makes up almost a half of all country's currency." The shock in Luis' eye was unmistakable.

It was Friday, December $16^{\text {th }}$. I'll never forget that date. The night before our father told us that our bank had run out of the new bank notes and we would have travel to another branch, this one located in El Callao. We had once been to El Callao; it was nothing more than a small southern mining town. Each person living there looked more starved than the next.

We were waiting in line with our worthless cash to exchange when we heard gun shots. The windows of grocery store across the street exploded and people 
were rushing out of the store covering their heads. Our father screamed to get down on the ground when men with face masks spilled out of the store. Officers came out the bank and started shooting at the masked men. All I could hear were screams and bullets flying by. My father held me and Luis tight. The gunfire only ceased when the gunmen jumped into their getaway cars and drove while officers on the streets were barking orders into their two way radios. That was when I saw Luis.

He was lying on the street, clutching on the duffle bags to his chest. A hole had been pieced through the bag and was dripping out blood. Not believing my eyes I ripped the duffle bag from my little brother's grasp to see his chest covered in his blood. I don't remember anything after that. My father told me days later that it was likely a bullet from the looter's gun that killed Luis.

It took until Sunday for Maduro to extend the deadline to exchange the bills to February $20^{\text {th }}, 2017$. It made me sick to think it took a 14 year old's death, rioting 
and looting for him to realize that our money doesn't mean anything. It doesn't matter how much of it you have, it's still paper.

Now when I see the new 500 Bs bank note, I think of my little brother. What I wouldn't pay to have him back. ${ }^{43}$

43 Post Script: Based on a true story published by The Guardian on December $18^{\text {th }}, 2016$ entitled, "Venezuela postpones bank note ban after chaos and cash shortages." In the article, the journalist describes a 14 year old boy shot dead in a looting in El Callao during the currency exchange. 


\section{Exclusion}

Exclusion, "to expel or bar especially from a place or position previously occupied." 44

In the spring of 1990, construction began on an exclusive six building complex designed by Enrique Gomez and Associates. The first building erected was to stand at $190 \mathrm{~m}$ tall (45 storeys) in the Capital District of Caracas. This center, officially named the Centro Financerio Confinanzas, was envisioned as a symbol of the economic strength and resiliency of Caracas. The skyscraper, rising above the Centro Financerio Confinanzas, was designed to accommodate office spaces, hotels and apartment-hotel-hybrids.

The skyscraper was nicknamed Torre de David, or Tower of David, in honour of developer J. David Brillembourg, who died after a long battle with cancer in 1993. In the summer of 1994, the 1994 Banking Crisis brought construction to a halt.

The widespread fear of expropriations transpiring under the control of President Hugo Chavez and his Bolivarian Government, as well as the government's incompetency in building enough homes for the citizens of Caracas laid the foundation for what has been called the largest vertical slum in the world. Over the course of several years, upwards to 2500 people took up residence in the unfinished Tower. In an effort to erase the blemish in the Capital District, in

\footnotetext{
44 "Exclude." Merriam-Webster. Merriam-Webster, n.d. Web. 21 Mar. 2017.
} 
2001 the Venezuelan government attempted to auction the building off, but no offers were made.

By 2011, the Tower was a thriving neighbourhood of independent business; bodegas, unlicensed dentist offices, hair and nail salons, workout gyms, barber shops, day cares, etc. Many of the dwelling spaces inside the Tower were built of found materials, mostly from around the abandoned construction site. Families retrofitted the spaces by demolishing walls and building new ones to accommodate for their own dynamics. Though without elevators, electricity, running water, balconies, railings and even windows in many areas, the Tower accommodated itself to a critical need for housing. On the site of what was once intended to be the most exclusive of corporate enclaves, the tower became, for a time, inclusive.

The rumours of the dangerous Tower housing only criminals were believed by those who lived in Barrios in and around Caracas, when in reality, the Tower became a sanctuary to citizens and their families who were willing to build their homes and maintain a civilized order that could not be found in the city. Squatters are motivated by the Tower cooperative to mop the corridors and clean up the trash in their homes, and obey to a democratic elected president of the Tower. ${ }^{45}$

\footnotetext{
45 Venezuela's Tower of Dreams. Dir. Olly Lambert. Perf. Elvys Merclan, Miriam Figueroa, Yecenia Polanco. Documentary. BBC Our World, 20 May 2014. Web. 31 Mar. 2017.
} 
Many permanent dwellers were happy with their living situations in the tower, explaining how the Tower, in many ways, was better organized than the country. ${ }^{46}$

On July 22nd, 2014, the Venezuelan government launched "Operation Zamora 2014," to evict and evacuate the families from the Tower and relocate them to Cúa, an area South of Caracas. Now, they have entered another realm exclusion. ${ }^{47}$

Though the direct translation of neighbourhood in Spanish is Barrio, Barrio has a negative connotation in Venezuela, as they are typically the dwelling for large families who live in poverty. These low class neighbourhoods, covering the hills around Caracas' CBD and the entire country of Venezuela have been recognized as having among the highest per capita murder rates in the world, with 116 homicides per 100,000 inhabitants, and most murders and other violent crimes go unsolved. ${ }^{48}$

\footnotetext{
${ }^{46}$ Venezuela's Tower of Dreams. Dir. Olly Lambert. Perf. Elvys Merclan, Miriam Figueroa, Yecenia Polanco. Documentary. BBC Our World, 20 May 2014. Web. 31 Mar. 2017.

47 BBC News. "Venezuela Tower of David Squatters Evicted." BBC News. BBC, 22 July 2014. Web. 31 Mar. 2017.

48 Data Team, The. "The World's Most Violent Cities." The Economist. The Economist Newspaper, 03 Feb. 2016. Web. 21 Mar. 2017.
} 


\section{Bibliography}

Abercrombie, Thomas, J. "Venezuela Builds on Oil." National Geographic Magazine. National Geographic Society. Vol. 123, No.3. Washington, D.C. March, 1963.

Banco Central De Venezuela. "Bolivar Fuerte: Una economia fuerte, un Bolivar fuerte, un pais fuerte." Banco Central De Venezuela. Pamphlet. 2007. Acquired 2007. Translated in English by author.

BBC News. "Venezuela Tower of David Squatters Evicted." BBC News. BBC, 22 July 2014. Web. 31 Mar. 2017.

BBC News. "Venezuela Tower of David Squatters Evicted." BBC News. BBC, 22 July 2014. Web. 31 Mar. 2017.

Boyd, Sebastian. "Black-Market Bolivars Crash Past 1,000 Per Dollar in Venezuela."Bloomberg.com. Bloomberg, 03 Feb. 2016. Web. 28 Mar. 2017.

Brooke, James. "Failure of High-Flying Banks Shakes Venezuelan Economy." The New York Times. The New York Times, 15 May 1994. Web. 21 Mar. 2017. Coronil, Fernando. "Oil and Revolution." Venezuela: The Chavez Effect. ReVista: Harvard Review of Latin America. David Rockefeller Center for Latin American Studies. Vol. VIII, No.1. Harvard University. Fall 2008.

Coronil, Fernando. "Oil and Revolution." Venezuela: The Chavez Effect. ReVista: Harvard Review of Latin America. David Rockefeller Center for Latin American Studies. Vol. VIII, No.1. Harvard University. Fall 2008. 
"Corrupt." Merriam-Webster. Merriam-Webster, n.d. Web. 21 Mar. 2017.

Data Team, The. "The World's Most Violent Cities." The Economist. The Economist Newspaper, 03 Feb. 2016. Web. 21 Mar. 2017.

Dateandtime.com. "Caracas, Venezuela.". Latitude, Longitude, and Elevation above Sea Level of Caracas. Date and Time.com, n.d. Web. 30 Mar. 2017. "Defect." Merriam-Webster. Merriam-Webster, n.d. Web. 21 Mar. 2017.

"Deprive." Merriam-Webster. Merriam-Webster, n.d. Web. 21 Mar. 2017.

DolarToday.com. "Noticias De Venezuela Y Dolar Paralelo." DolarToday. DolarToday Publicacion, 28 Mar. 2017. Web. 28 Mar. 2017.

Dreier, Hannah. "Life on the Line in Venezuela as Economic Crisis Worsens." AP. The Big Story, 12 Jul. 2016. Web. 27 Mar. 2017

"Exchange." Merriam-Webster. Merriam-Webster, n.d. Web. 21 Mar. 2017.

"Exclude." Merriam-Webster. Merriam-Webster, n.d. Web. 21 Mar. 2017.

Feinberg, Gerald, and Maurice Goldhaber. "The Conservation Laws of Physics." Scientific American. Scientific American Published, 26 Aug. 2013. Web. 21 Mar. 2017.

Forero, Juan. "Venezuela Imposes Currency Controls to Shore Up Economy." The New York Times. The New York Times, 06 Feb. 2003. Web. 25 Mar. 2017. Frankling, Jonathan. "Counterfeiting is an art." The Guardian. The Guardian Press, 31 Mar. 2016. Web 27 Mar. 2017 
Gillespie, Patrick. "5 Reasons Why Venezuela's Economy Is in a 'meltdown'." CNNMoney. Cable News Network, 20 Jan. 2016. Web. 21 Mar. 2017.

Henry, Leigh. "Hawksbill Turtle." WWF. World Wildlife Fund, n.d. Web. 31 Mar. 2017.

"Inflation." Merriam-Webster. Merriam-Webster, n.d. Web. 21 Mar. 2017.

J. R. A. "Why Airlines Are Abandoning Venezuela." The Economist. The Economist Newspaper, 08 June 2016. Web. 21 Mar. 2017

Marden, Luis. "Caracas, Cradle of The Liberator: The Spirit of Simon Bolivar, South American George Washington, Lives On in the City of His Birth.” 
National Geographic Magazine. National Geographic Society. Vol. LXXVII, No.4. Washington D.C. April 1940

OPEC. "Member Countries." OPEC : Member Countries. Organization of the Petroleum Exporting Countries, 2015. Web. 21 Mar. 2017.

OPEC. "Venezuela." OPEC : Venezuela. OPEC, Jan. 2017. Web. 25 Mar. 2017. Original author. "Letter to Elba." Dramatized non-fiction.

Parraga, Marianna, and Alexandra Ulmer. "Venezuela's Energy Woes Spread to Its Closest Ally: Cuba." Reuters. Thomson Reuters, 08 July 2016. Web. 21 Mar. 2017.

PDVSA. "History." Petroleos De Venezuela SA. Gobierno Bolivarian De Venezuela, n.d. Web. 30 Mar. 2017.

Pennsylvania State University. "Fifty-Fifty: The New Deal in Oil." Oil: International Evolution. Penn State College of Earth and Mineral Science, n.d. Web. 21 Mar. 2017.

Rapoza, Kenneth. "Venezuela's Inflation Rate Now Approaching Lunacy Levels." Forbes. Forbes Magazine, 26 Aug. 2016. Web. 25 Mar. 2017.

Tong, Scott. "A Day out at the (black) Market in Venezuela." Marketplace. Panama Post, 3 Apr. 2016. Web. 27 Mar. 2017.

"Venezuela postpones bank note ban after chaos and cash shortages." The Guardian, 18 Dec. 2016. Web. 27 Mar. 2017 
Venezuela's Tower of Dreams. Dir. Olly Lambert. Perf. Elvys Merclan, Miriam Figueroa, Yecenia Polanco. Documentary. BBC Our World, 20 May 2014. Web. 31 Mar. 2017.

Zerpa, Fabiola, and Andrew Rosati. "Venezuelans Give Up on Counting Piles of Cash and Start Weighing Them." Bloomberg.com. Bloomberg, 31 Oct. 2016. Web. 31 Mar. 2017. 